\title{
Panorama esquemático de la literatura de los jesuitas mexicanos expulsos (1767-1830)
}

Schematic overview of the Mexican literary of the Jesuits expelled (1767-1830)

Antonio Astorgano Abajo* Fuensanta Garrido Domené ${ }^{* * *}$

\section{Resumen}

Estudiamos la obra literaria de los jesuitas mexicanos expulsos, recogida por el abate Lorenzo Hervás y Panduro (1735-1809), en su Biblioteca jesuítico-española (BJE). Asimismo narramos las penosas peripecias vitales de los jesuitas novohispanos exiliados, principalmente a la luz del Diario del jesuita Manuel Luengo y del Menologio del P. Félix de Sebastián.

\section{Palabras clave}

Abate Lorenzo Hervás y Panduro, jesuitas expulsos mexicanos, Literatura silenciada, Biblioteca jesuítico-española.

\footnotetext{
* Doctor en Filología Hispánica por la Universidad Complutense de Madrid. Profesor jubilado de Literatura Española de la Universidad de Zaragoza, España.

** Doctora en Filología Clásica y profesora de la Facultad de Humanidades de la Universidad de Huelva, España.
} 


\begin{abstract}
We study the literary works of the Mexican Jesuits expelled, collected by the Abbé Lorenzo Hervás y Panduro (1735-1809), in his Jesuit-Spanish Library (BJE). Also narrate the painful life adventures of the exiled Jesuits from New Spain, especially in light of the Journal of the Jesuit Manuel Luengo and P. Menology Felix Sebastian.
\end{abstract}

\title{
Key-Words
}

Abbot Lorenzo Hervás y Panduro, Mexican expelled jesuits, silenced Literature, Spanishjesuitic Library.

Recibido: 15 de diciembre de 2013

Evaluado: 14 de enero de 2014 


\section{Introducción.}

En los dos únicos lugares de Iberoamérica en los que pudo implantarse la Compañía de Jesús inmediatamente después de su restauración universal por Pío VII (agosto de 1814) fue en España y en México ${ }^{1}$, lo cual no sólo se debió al número de supervivientes de la Antigua Compañía, expulsada en 1767 y suprimida en 1773, sino también a la buena memoria que durante casi medio siglo supieron mantener, principalmente con la pluma, sus intelectuales y escritores. Con motivo del bicentenario de la restauración de la Compañía de Jesús en México, hemos compuesto varios artículos sobre la literatura de su exilio ${ }^{2}$, como hicimos en el 2009 con la Asistencia de Portugal al rememorar el cruel destierro de Pombal $^{3}$.

El presente artículo tiene por objeto presentar un panorama de todos los jesuitas expulsos mexicanos que escribieron algo literario, de lo que tenemos noticia (un centenar aproximadamente), con la finalidad de romper el cerco marcado por la docena y media de escritores novohispanos que hasta el presente se han venido manejando por los estudiosos. Nuestras fuentes principales son el menologio del biógrafo Félix de Sebastián (San Lúcar de Barrameda, 1736-Bolonia, 1815) y el repertorio del polígrafo abate Lorenzo Hervás y Panduro, jesuita manchego expulso y apasionado hombre de letras (*Horcajo de Santiago, Cuenca, 1735- $\dagger$ Roma, 1809), autor de la monumental Biblioteca jesuítico-española de escritores que han florecido por siete lustros desde el año 1759, principio del reinado del Augusto Rei Católico Carlos III, y acaban en el año 1793 (en lo sucesivo BJE), que comprende cuatro catálogos que se conservan originales en dos tomos manuscritos de Hervás, muy deteriorados, en el Archivo Histórico de Loyola ${ }^{5}$, en la que se ocupa de recoger todas las obras escritas (publicadas o no) durante 1759-1799 por los miembros luso-españoles de la Compañía de Jesús. En 2007 publicamos el tomo I de la $B J E^{6}$, la cual reviste bastante interés para el conocimiento del estado de los más de 6000 jesuitas lusoespañoles desterrados en los Estados Pontificios, durante la segunda mitad del siglo XVIII, por la minuciosa información bio-bibliográfica contemporánea que nos suministra el abate manchego. En otros lugares hemos estudiado específicamente la literatura de los jesuitas vas $\cos ^{7}$ y portugueses expulsos a la luz de la citada $B J E$. Ahora vamos a hacer lo mismo con cierto detenimiento respecto a la de los novohispanos, que ya tratamos tangencialmente en un congreso celebrado en Tlaxcala, donde analizamos las muchas amistades que el abate español tuvo entre los expulsos mexicanos ${ }^{8}$.

A lo largo del estudio de la producción literaria de las distintas provincias de los jesuitas expulsos españoles hemos observado que, aproximadamente, un 10\% del total dejó

\footnotetext{
${ }^{1}$ Bangert, 1981: 544-547.

${ }^{2}$ Astorgano Abajo, 2014a; 2014b.

${ }^{3}$ Astorgano, 2009a: 265-283; 2009b, 305-417; 2009c: 315-336; 2009d: 359-374.

${ }^{4}$ Sebastián, 1767-1796.

${ }^{5}$ AHL, Escritos de jesuitas del siglo XVIII, Caja 06, $\mathrm{n}^{\circ} 01$.

${ }^{6}$ Hervás y Panduro, 2007; Hervás y Panduro, 2008.

${ }^{7}$ Astorgano Abajo, 2009g.

${ }^{8}$ Ibíd., 2009e: 201-254.
}

61 Antonio Astorgano Abajo y Fuensanta Garrido Domené. Panorama esquemático ... 60-120. 
algún escrito y un $1 \%$ redactó obras literarias de relevancia cultural en la Europa de la Ilustración. Así, de los casi 5500 jesuitas españoles expulsos, salieron unos 600 escritores, $\mathrm{y}$, de estos, unos 60 con obras que todavía atraen la atención del lector del siglo XXI. Si trasladamos esta proporción a los jesuitas expulsos mexicanos, cabría esperar que de los 650 exiliados de Nueva España deberían haber salido unos setenta escritores, de los cuales una decena tendría obras relevantes. En efecto, nos encontramos con que se cumplen bastante esas expectativas, pues, Hervás puede reseñarnos hasta 1794, con añadiduras hasta 1799, 63 escritores (que presentamos en la tabla-resumen I) entre los jesuitas mexicanos expulsos, de los cuales importantes son media docena, relevancia reflejada en la extensión que tienen los respectivos artículos (más de un folio en letra 10 de ordenador).

En una segunda tabla-resumen presentamos la producción literaria de otros 44 jesuitas mexicanos que se le escaparon a Hervás, tomando otras fuentes (Félix de Sebastián, Mariano Beristáin ${ }^{9}$ y Uriarte $^{10}$ y Lecina ${ }^{11}$, principalmente). Sin duda, también a nosotros se nos habrá "olvidado" algún otro escritor salido de entre los expulsos mexicanos, lo cual es inevitable en toda obra recopilatoria.

Siguiendo a Rafael de Zelis ${ }^{12}$, en 1767 la Provincia jesuita de México estaba compuesta por 678 miembros, nacidos entre 1686 y 1751, de los cuales un centenar aproximadamente dejó algún escrito literario. Para hacernos una idea de los escritores surgidos en cada "generación" vamos a dar la relación por décadas entre nacidos y escritores venidos al mundo en cada una de ellas, advirtiendo que en el devenir de la agitada vida de la Provincia mexicana expulsa todas las "generaciones" o décadas dieron sus mejores frutos en el periodo 1774-1790, capitaneados por un puñado de plumas ilustres nacidas hacia 1730, que alcanza su madurez ignaciana en la profesión solemne del cuarto voto del 15 de agosto de 1763 (Diego José Abad, Salvador Dávila, Agustín Pablo de Castro, José Julián Parreño, Manuel Mariano de Iturriaga, Joaquín Leguinazábal y Francisco Javier Alegre), y del 2 de febrero de 1765 (Antonio Sternkianowski, Blas Arriaga, Juan Ignacio González Anda, Bartolomé Cañas, Francisco Javier Rivero, Francisco (Ita) Hita, Francisco Javier Clavijero, Dionisio Pérez y Rafael Landívar), donde encontramos los nombres más significativos de la literatura exiliada. Es la generación que llega a Italia con plenitud vital (entre 35 y 40 años), que habían recibido una sólida formación humanística de maestros que no sobrepasaban los 45 (el más significativo es Rafael Campoy, nacido en 1723).

En torno a esta dorada generación se distribuye el resto de escritores de la forma siguiente:

\footnotetext{
${ }^{9}$ Beristáin, 1816-1821.

${ }^{10}$ Uriarte, 1904-1916.

${ }^{11}$ Uriarte- Lecina, 1925-1930.

${ }^{12}$ Zelis, 1871.
}

62 Antonio Astorgano Abajo y Fuensanta Garrido Domené. Panorama esquemático ... 60-120. 


\begin{tabular}{|c|c|c|c|}
\hline Década & $\begin{array}{l}N^{0} \text { de } \\
\text { jesuitas } \\
\text { expulsos } \\
\text { nacidos } \\
\text { durante } \\
\text { esa década }\end{array}$ & $\begin{array}{l}N^{0} \text { de } \\
\text { jesuitas } \\
\text { expulsos } \\
\text { escritores } \\
\text { de esa } \\
\text { década }\end{array}$ & $\begin{array}{l}\text { Nombres de los escritores expulsos de los que tenemos } \\
\text { noticia, según la } B J E \text { de Hervás, Félix de Sebastián, } \\
\text { Beristaín, etc., advirtiendo que algunos no llegaron al } \\
\text { destierro (se quedaron en América o fallecieron antes del } \\
\text { embarque) y que Hervás incluye alguno fallecido entre } 1759 \text { y } \\
1767 \text { (una decena que no aparece en esta tabla, pero sí en las } \\
\text { tala-resumen). }\end{array}$ \\
\hline $1786-1700$ & 26 & 5 & $\begin{array}{l}\text { Juan Arriola, Juan Francisco López, José Ortega, José Bellido, } \\
\text { José Carrillo. }\end{array}$ \\
\hline $1701-1710$ & 83 & 10 & $\begin{array}{l}\text { Santiago Sedelmayer, Pedro Pablo Macida, Pedro Reales, Juan } \\
\text { Antonio Araoz, Francisco Javier Zeballos (Ceballos), Andrés de } \\
\text { la Fuente, Miguel del Barco, José Utrera, Salvador de la Gándara, } \\
\text { Ignacio Aramburu. }\end{array}$ \\
\hline $1711-1720$ & 112 & 15 & $\begin{array}{l}\text { Nicolás Calatayud, Nicolás Peza, Miguel Benjumea, Sancho } \\
\text { Reinoso, Antonio Ágreda, José Urbiola, José Lucas Anaya, } \\
\text { Santiago Begert, Juan Roset, Gabriel Carabantes, José Ignacio } \\
\text { Vallejo, Vicente Zuazu, José Mariano Vallarta, Andrés } \\
\text { Prudencio Fuente, Francisco Miranda. }\end{array}$ \\
\hline $1721-1730$ & 145 & 28 & $\begin{array}{l}\text { Manuel Colazo, José Estrada, Benno Ducrue, Javier Lozano, José } \\
\text { Restán, Bernardo Middendorf Rodenborg, José Campoy, } \\
\text { Francisco Ganancia, Juan Ignacio González, Antonio Corro, Juan } \\
\text { Ignacio Mota, Ignacio Pfefferkorn Eschenbrender, Joaquín } \\
\text { Truxillo, Juan Antonio Nava, Tomás Pérez Díaz, Salvador } \\
\text { Dávila, Lucas Ventura, Diego José Abad, Agustín Castro, } \\
\text { Antonio Sternkianowski, José Julián Parreño, Manuel Mariano } \\
\text { Iturriaga, Joaquín Leguinazábal, Blas Arriaga, Bartolomé Cañas, } \\
\text { Francisco Javier Alegre, Javier Rivero, Antonio López de Priego. }\end{array}$ \\
\hline $1731-1740$ & 197 & 28 & $\begin{array}{l}\text { José Izquierdo, Francisco Hita (Ita), Francisco Javier Clavigero, } \\
\text { Dionisio Pérez Díaz, Antonio Sternkianowski, Rafael Landívar, } \\
\text { Domingo Esparza, Nicolás Noroña, Francisco Javier Rodríguez, } \\
\text { Juan Sacrameña, Blas Miner, Juan de Dios Noriega, Simón Arce, } \\
\text { Manuel Brito, Antonio Poveda, Pedro Gallardo, Manuel } \\
\text { González Cantabrana, Narciso González, Félix José de Sebastián, } \\
\text { José Gondra, Manuel Fabri, José Liébana, Juan Chaves, Andrés } \\
\text { Cavo, Manuel Cote Muñoz (Muñoz Cote), Hilario Ugarte, } \\
\text { Manuel Arenas, Eligio Fernández, Juan Antonio Doporto } \\
\text { Andrade y José de Lava Ribera. }\end{array}$ \\
\hline $1741-1751$ & 115 & 10 & $\begin{array}{l}\text { Pedro José Márquez, Dámaso Preen, Juan Luis Maneiro, Ramón } \\
\text { Tarroz (Tarrós), José Toledo, José María Castañiza, Pedro } \\
\text { Cantón, Lino José Fábrega, Rafael de Zelis y Andrés Guevara } \\
\text { Basoazábal. }\end{array}$ \\
\hline
\end{tabular}

Una ojeada superficial a esta tabla muestra que la primera y la última década presentan menos expulsos, la primera (1686-1700) por razones de edad, y la última (1741- 
1751) por las persecuciones y deserciones fomentadas por las autoridades borbónicas (recuérdese el caso de los novicios), sin embargo se diferencian en la calidad de los más jóvenes (Márquez, Guevara, Fábregas, Maneiro...), que contrasta con los viejos teologones de principios del siglo XVIII.

Curiosamente las dos décadas centrales (1720-1740) presentan el mismo número de escritores, con una calidad cada vez más elevada en su obra, estimulada por la nostalgia y defensa del hombre y del paisaje americanos, que culmina con los escritos de tipo poético, etnográfico e histórico de los grandes autores nacidos en la década de 1731-1740 (Clavigero, Landívar, Andrés Cavo...).

En todo caso, no creemos que el investigador que indague en los archivos de México, Roma, Bolonia y Ferrara, donde residieron la mayoría, o en los de otras ciudades de los Estados Pontificios, donde se refugiaron algunos jesuitas mexicanos, pueda enriquecer significativamente el panorama intelectual que hasta el presente ofrece su historia literaria, reseñada en las tablas que aquí adjuntamos, en las que no hemos incluido algunos autores a los que sólo se le conocen algunas poesías de circunstancias, como por ejemplo, Juan Antonio Doporto Andrade (*Laguna de Término (Mérida de Yucatán; según Zelis en Isla del Carmen), 2-III-1733-†Bolonia, 26-IV-1801) y José de Lava Ribera (*Guadalajara, 1-X-1738-†Bolonia, 9-IX-1806), quienes compusieron unas insulsas décimas, incluidas al final del manuscrito, en elogio de la Historia del arresto, expatriación, viaje a Italia y extinción de la Provincia Mexicana de la Sagrada Compañía de Jesús, de Antonio López de Priego.

\section{Observaciones para comprender las tablas-resumen}

\subsection{La estructura de las dos tablas-resumen}

Las dos tablas-resumen tienen cuatro columnas (en la primera, que recoge los 63 autores de la $B J E$, se añade una quinta con la extensión en letra 10 de ordenador que le atribuye Hervás a cada escritor), estructura que viene a coincidir con la que tiene cada uno de los artículos de la $B J E$, los cuales están organizados en dos partes, además del encabezamiento. Una biográfica aporta los datos sobre la vida (nacimiento, muerte, familia, fuentes, [en especial Maneiro]...), sobre su relación con la Compañía (ingreso, profesión solemne, estudios, cargos...) y sobre su exilio (residencias en Córcega, Italia, anécdotas...). La segunda parte es bibliográfica, subdividida en impresos (suele empezar con la palabra "imprimió" y aporta datos sobre ciudad, editor, tamaño, reseñas bibliográficas...) y manuscritos (parte única en los escritores del Catálogo II, dedicado a los que carecen de obra publicada, y empieza con los vocablos "manuscritos" o "escribió") con bastantes títulos imprecisos y algunas observaciones sobre sus avatares editoriales.

\subsection{Hacia una periodización de la literatura del exilio de los jesuitas mexicanos expulsos (1767-1814)}

A la hora de clasificar y aquilatar la valoración del centenar de autores mexicanos expulsos, podemos seguir tres criterios principales: el cronológico, el geográfico y el

64 Antonio Astorgano Abajo y Fuensanta Garrido Domené. Panorama esquemático ... 60-120. 
temático, que es el más utilizado y el que siguieron Miguel Batllori ${ }^{13}$ y Eva María St. Clair Segurado $^{14}$. Para poner un poco de orden en la masa de escritores hemos destacado en columna aparte los datos relativos a las fechas de nacimiento y muerte, como sintomáticos de una ordenación cronológica de la literatura de los expulsos mexicanos, que hemos expuesto ampliamente en otro lugar ${ }^{15}$, y que ahora resumimos muy brevemente.

A pesar de todos los inconvenientes que presentan las periodizaciones, por su simplicidad y por las dificultades de poner límite a algo que está en constante fluctuación como es el tiempo, la vida y la obra de un escritor, vamos a proponer la división de la producción literaria de los jesuitas mexicanos desterrados (1767-1814) en cuatro periodos, dentro de las cuales se podrían subdividir otras subetapas de menor importancia, que desechamos en orden a la claridad y sencillez.

Desde un punto de vista jesuítico más tradicional, a la hora de la reconstrucción histórica de la literatura del exilio de los jesuitas portugueses y españoles, hay que señalar dos tiempos bien definidos por el hecho de la extinción de la Compañía en agosto de 1773. El primero abarca el tramo temporal 1767-1773 en que los desterrados mexicanos son todavía miembros activos de la Compañía de Jesús y por ende su pertenencia a la Asistencia de España traza sus cauces institucionales, cuyas huellas no han sido estudiadas todavía, pero podemos intuir bastante detalladamente a través del Diario del P. Manuel Luengo, residente en Bolonia, como la gran mayoría de los jesuitas mexicanos. Esta etapa histórica (1767-1773) merece un estudio especial, aunque, en el caso de los jesuitas americanos, más que por los escritos literarios, por las mil peripecias y algunas humillaciones a que fueron sometidos por el excesivo celo de algunos comisarios reales (en Guadalajara, por ejemplo) y el comportamiento poco caritativo de los jesuitas italianos de Bolonia (no así los de Ferrara), y las ambiguas órdenes emitidas por el gobierno del Vaticano, narradas por varios cronistas jesuitas.

El segundo tiempo o periodo en que se puede dividir el estudio la literatura de los jesuitas mexicanos expulsos se inicia en 1773 con el Breve exterminador de Clemente XIV Dominus ac Redemptor, por el cual, al hecho histórico del destierro impuesto por Carlos III, hay que añadir el de la extinción de la orden jesuítica por el Papa Ganganelli, la cual obligaba a desintegrar toda la institucionalidad religiosa y a dispersar a todos sus miembros. El hecho de la extinción canónica produjo un profundo abatimiento en los jesuitas mexicanos (dispersos entre Bolonia y Ferrara), según va relatando F. de Sebastián en las distintas necrológicas, aunque quizá menor que en los ignacianos de otras provincias por la mayor libertad respecto a su provincial, traducida en un elevado número de secularizaciones ${ }^{16}$. Cronológicamente, la "literatura de exilio" abarca tanto la literatura del destierro (1767-1773) como la de la extinción (1773-1814).

\footnotetext{
${ }^{13}$ Batllori, 1966.

${ }^{14}$ Saint Clair Segurado, 2005: 407-438.

${ }^{15}$ Astorgano Abajo, 2014a; 2009c.

${ }^{16}$ En 1768 se secularizaron 29 jesuitas, en 1769 otros 20, en 1770 otros 14 y otros 15 en los tres años posteriores (1771-1773). Saint Clair Segurado, 2005: 339.
} 
Por nuestra parte, vamos a concretar los periodos de esta literatura del exilio, siguiendo la división que ya sugerimos al estudiar el conjunto de los jesuitas expulsos españoles $^{17}$, $\operatorname{vascos}^{18}$ y portugueses ${ }^{19}$, reseñados por Hervás en su $B J E$, que ahora aplicaremos a la literatura del exilio de los jesuitas mexicanos expulsos (1767-1814).

Un primer periodo, fuertemente represivo, va desde la expulsión de 1767 hasta la subida al poder de Floridablanca y la defenestración de Pombal en 1777, dentro del cual distinguimos dos subperiodos: Subperiodo $1^{\circ}$. Desde la expulsión de 1767 hasta la supresión de la Compañía (agosto de 1773), en el transcurso del cual fallecen 6 literatos mexicanos reseñados por Hervás. Los diplomáticos regalistas españoles comunican con frecuencia que cada vez aparecen más escritos jesuíticos, algunos claramente subversivos, bastantes redactados, en opinión de José Nicolás de Azara, en Ferrara, donde residirán los expulsos aragoneses y mexicanos.

En un segundo subperiodo (1773-1777), los ahora ex jesuitas utilizan la libertad que les dio la supresión de la Compañía para perder el miedo a escribir más y sobre variados temas, sobre todo en ciudades, como Ferrara, donde el contexto sociopolítico les era más favorable. El 29 de mayo de 1777, el diplomático español denuncia la interceptación de un libelo jesuítico en Ancona contra las regalías pontificias y la autoridad de la curia, y de otro contrario al venerable Juan de Palafox, a quien se le considera hereje jansenista; cree que es obra de los jesuitas residentes en ferrara, "el centro, y el nido de las principales intrigas jesuíticas, y donde se fraguan la mayor parte de estos escritos de tinieblas y cuentan con la protección de autoridades eclesiásticas y políticas", incluido el nuevo arzobispo Alessandro Mattei, "que es el más fanático, terco y zelante jesuita de cuantos prelados había en Roma" $"$.

Periodo $2^{\circ}$. Periodo de esplendor: desde 1778 (aparición de los grandes proyectos literarios de Hervás, Clavigero, Llampillas, Juan Andrés) hasta el inicio de la Revolución Francesa (1789), a lo largo del cual fallecen 20 literatos mexicanos, incluidos Diego José Abad, Francisco Javier Alegre, Rafael de Landívar y Francisco Javier Clavigero, periodo de esplendor de la Literatura mexicana, en la que jugó un papel esencial la Imprenta Biasini ${ }^{21}$. La literatura jesuita novohispana expulsa alcanza su esplendor en esta década en torno a la "generación", nacida hacia 1730 y que emitió su cuarto voto el 2 de febrero de 1765 (Blas Arriaga, Juan Ignacio González Anda, Antonio Sternkianowski, Bartolomé Cañas, Javier Rivero, Francisco Hita Santana, Francisco Javier Clavigero, Rafael Landívar).

Década verdaderamente dorada, en la que también se elaboran las mejores obras de los escritores que fallecerán en la década siguiente, como Miguel del Baco, Rafael Landívar y Juan Luis Maneiro. Los desterrados más inquietos intelectualmente aprovecharon la libertad que supuso la extinción de la compañía (hubo otros, en el extremo opuesto, que se

\footnotetext{
${ }^{17}$ Astorgano Abajo, 2007: 43-51; 2004: 182-190.

${ }^{18}$ Hervás y Panduro, 2007; Hervás y Panduro, 2008.

${ }^{18}$ Astorgano Abajo, 2009g.

${ }^{19}$ Ibíd., 2009c: 315-336.

${ }^{20}$ AGS, Estado, legajo 4999.

${ }^{21}$ Astorgano Abajo, 2014b.
}

66 Antonio Astorgano Abajo y Fuensanta Garrido Domené. Panorama esquemático ... 60-120. 
pasaron el resto de su vida lamentándolo) y las ventajas económicas y "mayor apertura" ideológica facilitadas a los jesuitas expulsos por el nuevo primer ministro, conde de Floridablanca (político práctico que evolucionó del furibundo antijesuitismo a la coexitencia, y hasta colaboración, provechosa para ambas partes) ${ }^{22}$, y por la nueva y "piadosa" reina de Portugal, María I. Realmente se puede decir que la producción literaria de los jesuitas tomó nuevos rumbos y temas después que Floridablanca dejase la embajada ante la Santa $\operatorname{Sede}^{23}$, aunque tuviese la lógica invernación durante los cuatro años anteriores desde que la supresión de la Compañía, en agosto de 1773, dejó a cada ex jesuita dueño de su destino ("ociosos enteramente") y alguno buscó aires de mayor libertad en Venecia, Génova, etc.

A lo largo de esta década dorada de la literatura novohispana fallecen, al menos, 22 escritores novohispanos, entre ellos José Vallejo en 1785, Francisco Javier Clavigero en 1787 y Francisco Javier Alegre en 1788. Poco después a lo largo de 1790 fallecen el excelente humanista y filósofo José Mariano Vallarta, el misionero Miguel del Barco y el humanista Agustín Pablo de Castro, biógrafo de Clavigero. En esta maravillosa década, muchos novohispanos viajan a Roma, y no pocos escritores, los más jóvenes, se domicilian en la Ciudad Eterna, como Andrés de Cavo, siempre al lado de su maestro José Julián Parreño, Lino José Fábrega, Manuel Fabri, Pedro José Márquez o Mariano Antonio Poveda. El jesuitismo va perdiendo peso demográfico y literario en la Romaña y lo va cogiendo en Roma, a donde emigran los intelectuales más inquietos.

El Periodo $3^{\circ}$ es una década de contracción en la producción literaria, que abarca desde el inicio de la Revolución Francesa (1789) hasta la invasión napoleónica de Italia (1796-1798), a lo largo de la cual fallecen trece literatos mexicanos de los reseñados por Hervás, como el humanista y poeta latino Manuel González Cantabrana, el latinista y matemático Narciso González de Anda, el citado pedagogo, filósofo y teólogo José Mariano Vallarta y Palma ${ }^{24}$, el poeta y biógrafo Agustín Pablo de Castro y Tembra ${ }^{25}$, el poeta Rafael de Landívar Ruiz de Bustamante ${ }^{26}$, el historiador Lino Josef Fábrega Bustamante, el importante misionero, antropólogo e historiador extremeño Miguel del Barco González, el

\footnotetext{
${ }^{22}$ Ibíd., 2009f: 325-362. Pombal (Diario, día 2.12.1776).

${ }^{24}$ Sebastián, 1767-1796, vol. II, f. 162.

${ }^{25}$ Ibíd., 1767-1796, vol. II, f. 197.

${ }^{26}$ Ibíd., 1767-1796, vol. II, f. 255.
}

${ }^{23}$ A finales de noviembre de 1776 Luengo analiza la noticia de la promoción de Floridablanca, cuyo único mérito era el haber estado cuatro años (1772-1776) de embajador en Roma oprimiendo a la Compañía hasta conseguir su extinción. Por eso el ascenso de Moñino a primer secretario de Estado no dejaba de ser un alivio para los exjesuitas, pues era sustituido por un veterano político menos fanático, como era el duque de Grimaldi, concluyendo el diarista: “[...] por medios todos injustos, impíos, violentos, tiránicos, logró aterrar al apocado Pontífice Ganganelli y violentarle a que contra su voluntad, su honor y su conciencia extinguiese en todo el mundo la ilustre e inocente Compañía de Jesús. [...] Moñino no sabe más que cuatro párrafos de Leyes ni ha manejado otros negocios que el de la extinción de la Compañía" (Diario, día 26.11.1776). Aunque Luengo menospreciaba el pragmatismo político de Floridablanca, tiene sus dudas: "El tiempo mostrará si nos engañamos y tendremos cuidado de notarlo en este escrito después que le veamos ir a España a tomar posesión de su empleo". A la semana siguiente anota con disimulada alegría la muerte de otro enemigo de los jesuitas, la del cardenal Francisco de Saldanha, Patriarca de la dicha ciudad, y aliado de

67 Antonio Astorgano Abajo y Fuensanta Garrido Domené. Panorama esquemático ... 60-120. 
misionero en Sonora desde 1754 Ignacio Pfefferkorn Eschenbrender, el cronista de la expulsión Rafael de Zelis Moreno, (*Veracruz, 23-X-1747-†Bolonia, 25-VII-1798), etc.

La vida en los Estados Pontificios era cada día más difícil, pues los precios estaban constantemente en aumento. Es un periodo en que la producción literaria de todos los desterrados disminuye en cantidad, pues van muriendo los ex jesuitas, y en originalidad, ya que muchas de las obras publicadas en este periodo son continuación de proyectos más o menos enciclopédicos empezados en el periodo anterior. Además, el temor generalizado a la Revolución, tanto en los mecenas como en los escritores objeto de protección, hace que surjan problemas de todo tipo: en las condiciones de serenidad para el trabajo, en la autocensura de temas (en general, los ex jesuitas atacaron a la Revolución francesa y a sus motores los filósofos y jansenistas), y en las posibilidades de impresión (pérdida de originales en los correos interceptados y menos dinero para mecenazgo...). En resumen, en la década de 1788-1798 la pluma del jesuitismo novohispano va apagándose poco a poco en medio de la tormenta revolucionaria y bélica, que apenas pueden sostener sexagenarios respetables septuagenarios, predominando, como es lógico, las memorias, más apologéticas que nostálgicas, que relatan episodios de la azarosa vida de la proscrita Provincia de México.

El periodo $4^{\circ}$ comprende desde la invasión de Italia (1796) y ocupación de Roma (1798) por Napoleón hasta la restauración universal de la Compañía por Pío VII (agosto de 1814) y libre retorno a sus patrias (1815-1816) de los pocos ignacianos que físicamente podían hacerlo. Periodo de descontrol, porque las circunstancias bélicas y políticas de Europa fraccionaron la comunicación entre los jesuitas ibéricos entre sí y con sus países de origen. Periodo de decadencia de la producción literaria de los ex jesuitas, a lo largo de la cual muere una docena de literatos, más preocupados por su supervivencia que por la producción literaria, aunque algunos supieron capear bastante bien los malos tiempos e incluso publicar lo mejor de sus escritos, como Pedro José Márquez. A lo largo de este periodo pasan a mejor vida conocidos ex jesuitas como el filósofo moderno y ecléctico Andrés [Ladrón] de Guevara y Basoazábal (†Plasencia [Italia], 25-III-1801), el poeta

Francisco Javier Lozano Ruiz, (†Elche [Alicante], 11-VI-1801), el lingüista y corresponsal de Hervás, Manuel Cote Muñoz, el biógrafo y latinista Juan Luis Maneiro Monsabal (†Ciudad de México, 16-XI-1802) ${ }^{27}$, el canonista y teólogo Mariano Antonio Poveda, (*†Roma, 1802), el humanista e historiador secularizado en 1769 Andrés de Cavo Alcaraz, (†Roma, 23-X-1803), el biógrafo Manuel Fabri Domínguez, (†Roma, 17-III1805), el importante cronista y biógrafo de jesuitas mexicanos Félix de Sebastián Pión, (†Bolonia, 29-VI-1815), el cronista Antonio María López de Priego, (†Bolonia, 22-I-1802), etc.

Habría que añadir media docena de supervivientes, que fallecieron entre $1815 \mathrm{y}$ 1830, entre los que se incluyen los restauradores Pedro José Márquez (†México, 1820), José María Castañiza (†México, 1816) y Pedro Cantón (†México, 1833); el teólogo polemista Manuel Mariano de Iturriaga (†Fano, 1819) y el predicador Josef Ángel Toledo Gutiérrez, (†Cremona, 1824), devoto del culto al Sagrado Corazón de Jesús, a la Virgen del Refugio en Guatemala y a la de Guadalupe (BJE, 531).

\footnotetext{
${ }^{27}$ Luengo, Diario, día 19.5.1793.
} 
Para el conocimiento sintético y panorámico de los avatares de la restauración de la Compañía de Jesús en México remitimos a Decorme ${ }^{28}$, quien resume que en 1814 sobrevivían unos 42 jesuitas mexicanos expulsos, de los cuales sólo 14 volvieron a la observancia regular en Roma (donde residían 15) o en México, siendo el menos anciano de todos el P. José Ignacio Amaya (68 años, nacido en Zacatecas en 1747, fue el único mexicano que acompañó a José Pignatelli a Nápoles en 1804) y el de más edad el P. Manuel Mariano Iturriaga ( 86 años $)^{29}$. Recordemos que, restaurada la Compañía por Pío VII (7 de agosto de 1814) y publicada la Real Cédula de Fernando VII (10 de septiembre de 1815) de restablecimiento en sus reinos por el virrey de Nueva España Félix M. Calleja (24 de febrero de 1816), se abrió (12 julio) el noviciado con ocho candidatos en el Colegio de $\mathrm{S}$. Ildefonso de México capital.

La perspectiva cronológica será importante para delimitar lo que pasó antes y después de la década prodigiosa de 1778-1788, y para ir más allá de la quincena de autores jesuitas expulsos mexicanos que se han venido estudiando hasta la fecha, agrupados, siguiendo el criterio temático, en los manidos grupos de los nostálgicos, que se dedicaron a tres materias: la apología de la obra jesuita en América, el estudio y exaltación del paisaje americano en obras científicas y poéticas, y el enaltecimiento del hombre americano con obras históricas, etnográficas y lingüísticas.

No podemos detenernos en narrar las cuatro etapas en las que hemos dividido la producción literaria de los jesuitas expulsos mexicanos ni en seguir la peripecia biográficoliteraria de los principales escritores de las tablas-resumen adjuntas, a las que deseamos dar todo el protagonismo en el presente artículo.

\footnotetext{
${ }^{28}$ Decorme, 1914, vol. I: 71-118.

${ }^{29}$ Ibíd.: 79.
}

69 Antonio Astorgano Abajo y Fuensanta Garrido Domené. Panorama esquemático ... 60-120. 


\section{TABLA-RESUMEN, $\mathbf{N}^{\circ} 1$}

Tabla-resumen de los literatos ex-jesuitas mexicanos que aparecen en la Biblioteca jesuítico-española de Hervás. Total 63 autores.

\begin{tabular}{|c|c|c|c|c|}
\hline $\begin{array}{l}{[-]=N^{\circ} \text { de }} \\
\text { orden } \\
\text { correlativo } \\
\text { del total de } \\
\text { jesuitas de los } \\
\text { cuatro } \\
\text { catálogos. } \\
\text { - Nombre. } \\
\text { - (-)= Tipo de } \\
\text { Catálogo. } \\
\text { - Provincia } \\
\text { jesuítica } \\
(\text { Alemania=A } \\
\text { LE.; } \\
\text { Aragón=AR; } \\
\text { Andalucía=A } \\
\text { ND; } \\
\text { Castilla=CAS } \\
\text {; Toledo=TO; } \\
\text { México=MEX }\end{array}$ & $\begin{array}{l}\text { - Actividad principal. } \\
\text {-Lugar de residencia en México en } \\
1767 \text { y en } 1773 . \\
\text { - Ciudad italiana de mayor } \\
\text { residencia hasta la redacción de la } \\
\text { Biblioteca de Hervás (1793). } \\
\text { - Otras observaciones biográficas. }\end{array}$ & $\begin{array}{l}\text { - Extensión } \\
\text { aprox. } \\
\text { concedida } \\
\text { por Hervás } \\
\text { en la } B J E \\
\text { en líneas de } \\
\text { ordenador. }\end{array}$ & $\begin{array}{l}\text { Col=Colaborador de Hervás o citado en otras } \\
\text { obras por él. } \\
\text { - Corresp=Aludido en la correspondencia de } \\
\text { Hervás. } \\
\text { Detall=Detalles que denotan trato con Hervás y } \\
\text { especial interés de éste. } \\
\text {-Grado y actividades dentro de la Compañía. } \\
\text { - Producción literaria publicada y manuscrita. }\end{array}$ & $\begin{array}{l}\text {-Fechas de nacimiento }(*) \text { y } \\
\text { muerte }(+) \text {. } \\
\text { - Otras observaciones. }\end{array}$ \\
\hline $\begin{array}{l}\text { [2] ABAD } \\
\text { SÁNCHEZ, } \\
\text { Diego Josef } \\
\text { (1). MEX. } \\
\text { Empleó el } \\
\text { seudónimo de } \\
\text { L'abbe } \\
\text { Selenopolitano } \\
\text {. Biografiado } \\
\text { por Manuel }\end{array}$ & $\begin{array}{l}\text { Humanista, filósofo y poeta, } \\
\text { representante en Méjico de la reacción } \\
\text { clásica e imitador de Virgilio. "Su } \\
\text { grande instrucción llamó la atención y } \\
\text { la estimación de los literatos, en que se } \\
\text { distinguieron Francisco Zanotti, } \\
\text { Eustaquio Zanotti, Sebastián } \\
\text { Canterzano y Clementino Vannetti, } \\
\text { doctos escritores. La Academia de } \\
\text { Roveredo lo adoptó entre sus socios". } \\
\text { En } 1767 \text { estaba de rector y profesor de }\end{array}$ & Importante & $\begin{array}{l}\text { Jesuita desde } 24-\mathrm{VII}-1741 \text {. Cuarto voto el } 15 \text {-VIII- } \\
\text { 1763. Desde } 1763 \text { trabajó en Querétaro sobre el } \\
\text { poema De Deo Deoque Homine Heroica, } \\
\text { publicado por vez primera en Venecia en } 1773 \text {. } \\
\text { “[...] Fue después prefecto de estudios del dicho } \\
\text { colegio de S. Ildefonso [que] en el tiempo de su } \\
\text { prefectura llegó a tener casi trescientos colegiales. } \\
\text { El Señor Abad se instruyó fundadamente no sólo en } \\
\text { las ciencias que enseñó, mas también en las } \\
\text { matemáticas y en la literatura, [...] tenía particular } \\
\text { gusto en cultivar la poesía. [...] Imprimió: } 1 . \text { De }\end{array}$ & $\begin{array}{l}\text { Jiquilpan (Michoacán; México), } \\
\text { 1-VI-1727- †Bolonia 1-X-1779 } \\
\text { (52, Santa María de la } \\
\text { Mascarella, IX,78). }\end{array}$ \\
\hline
\end{tabular}

70 Antonio Astorgano Abajo y Fuensanta Garrido Domené. Panorama esquemático ... 60-120. 


\begin{tabular}{|c|c|c|c|c|}
\hline Fabri $\left[n^{\circ} 70\right]$. & $\begin{array}{l}\text { Teología Escolástica en el Seminario } \\
\text { de Querétaro. Residió en Ferrara hasta } \\
\text { 1778, cuando su precaria salud lo forzó } \\
\text { a dirigirse a Bolonia con la esperanza } \\
\text { de encontrar un clima más favorable, } \\
\text { pero no fue así. Su salud empeoró y } \\
\text { falleció al año siguiente en dicha } \\
\text { cudad. En Italia intentó favorecer a los } \\
\text { escritores mejicanos. Así dio una } \\
\text { censura elogiosa del libro Vida de } \\
\text { nuestra Señora, pedida por su autor, } \\
\text { José Ignacio Vallejo (n } \text { n }^{\mathbf{0}} 49 \text { ), fechada } \\
\text { en Bolonia el } 25 \text { de noviembre de } \\
1778 \text {. }\end{array}$ & & $\begin{array}{l}\text { Deo Deoque homine heroica. Editio tertia } \\
\text { posthuma ex authoris mss. auctior, et correctior. } \\
\text { Caesenae, } 1780 \text {. Apud Gregorium Biasinium, vols. } \\
2 \text {, in } 8 .^{\circ} \text {. Esta obra, sin noticia del autor, se había } \\
\text { impreso en Venecia el año 1773, dando al autor el } \\
\text { nombre de Diego Labee Selenopolitano. (El } \\
\text { apellido Labee es el apellido español Abad } \\
\text { afrancesado; y el nombre Selenopolitano quiere } \\
\text { decir de la ciudad de la Luna, lo que según algunos } \\
\text { etimologistas significa el nombre Méjico). La dicha } \\
\text { obra se imprimió primeramente en Méjico con el } \\
\text { nombre de Musa Americana. } 2 \text {. Dissertatio ludrico- } \\
\text { seria de exterorum latinitate. Patavii, 1778. Typis } \\
\text { Seminarii, } 4^{\circ} \text {. Manuscritos: } 1 . \text { Nodus intricatior } \\
\text { matheseos solutus, seu ratio composita expedita et } \\
\text { ad tyronum captum accomodata. Un tomo en } 4^{\circ} .2 \text {. } \\
\text { Livini Meyer anima minusculo corpore conclusa; } \\
\text { seu epitome historiarum controversiarum de } \\
\text { auxiliis, un tomo en } 4^{\circ} .3 \text {. Compendio de áljebra. } 4 . \\
\text { Tratado del conocimiento de Dios. } 5 . \text { Geographia } \\
\text { hydrographica, seu de orbis terrarum fluminibus } \\
\text { precipuis. } 6 . \text { Dejó también manuscritos algunos } \\
\text { breves opúsculos, en prosa, y en verso latino y } \\
\text { español. Entre ellos se halla la octava égloga de } \\
\text { Virgilio, traducida en verso, y buena parte del } \\
\text { principio de los libros de la Eneida de Virgilio. } \\
\text { Parte de estas traducciones de Virgilio se imprimió } \\
\text { en Méjico con el título de Musa Americana" (BJE, } \\
\text { pp. } 95-98]^{30} \text {. }\end{array}$ & \\
\hline $\begin{array}{l}\text { [480] ALAÑA } \\
\text { [ALAGNA], } \\
\text { Josef (4). } \\
\text { SICILIA y } \\
\text { MEX. No fue } \\
\text { expulso. }\end{array}$ & $\begin{array}{l}\text { Explorador, cartógrafo, filólogo, } \\
\text { misionero y escriturista. Murió en La } \\
\text { Habana en } 1767 .\end{array}$ & 10. & $\begin{array}{l}\text { Jesuita desde } 11-\mathrm{III}-1722 \text {. "Imprimió, con su } \\
\text { nombre en España, una obra sobre la identidad de la } \\
\text { santa casa de Loreto y sobre sus diversas } \\
\text { traslaciones. Un tomo en octavo. Dejó manuscritos } \\
\text { algunos tomos de lecciones de Sagrada Escritura y } \\
\text { la exposición de los cantares sagrados" (BJE, p. }\end{array}$ & $\begin{array}{l}\text { * Palermo, 11-I-1702 (otros, } \\
\text { 1707)-†La Habana, 17-II-1767 }\end{array}$ \\
\hline
\end{tabular}

$\overline{{ }^{30} \text { Quiñones Melgoza, 2005: 374-376. }}$

71 Antonio Astorgano Abajo y Fuensanta Garrido Domené. Panorama esquemático ... 60-120. 


\begin{tabular}{|c|c|c|c|c|}
\hline & & & 742). & \\
\hline $\begin{array}{l}{[8]} \\
\text { ARAMBURU } \\
\text { ARANGUTI, } \\
\text { Ignacio (1). } \\
\text { MEX. }\end{array}$ & $\begin{array}{l}\text { Autor de catecismos. En } 1767 \text { estaba } \\
\text { en el Colegio de San Ildefonso de } \\
\text { Puebla de los Ángeles (prefecto de } \\
\text { Dolores y confesor). Residente en } \\
\text { Bolonia en } 1773 \text {. En } 1785 \text { residía en } \\
\text { Masa de Carrara, muy debilitado de } \\
\text { salud. }\end{array}$ & 5. & $\begin{array}{l}\text { Jesuita desde 23-XI-1729. Cuarto voto, el 15-VIII- } \\
\text { 1747. En Ferrara imprimió unas pláticas de } \\
\text { doctrina cristiana que se había traído de México } \\
\text { (Thesoro manual de la salvación, Ferrara, 1775). } \\
\text { Según F. Sebastián, "no aprobaban los mexicanos } \\
\text { esta determinación", por contener expresiones y } \\
\text { pensamientos "traídos con mucha fuerza y poca } \\
\text { solidez", y demasiados términos y frases propias de } \\
\text { aquellas partes (por su calidad de prédicas } \\
\text { populares) con poca conexión con el castellano }{ }^{31} \text {. } \\
\text { "Dejó manuscrita una obra intitulada: Catecismo } \\
\text { de doctrina cristiana, en la que se explica el } \\
\text { Catecismo del jesuita Jerónimo Ripalda" (BJE, pp. } \\
\text { 108-109). }\end{array}$ & $\begin{array}{l}\text { *Puebla de los Ángeles, 15-VII- } \\
\text { 1710- †Masa Carrara, 1-III } \\
\text { (29-II, según Zelis)-1788. }\end{array}$ \\
\hline $\begin{array}{l}\text { [9] ARCE Y } \\
\text { ARROYO } \\
\text { ECHEGARAY, } \\
\text { Simón (1). } \\
\text { MEX. (Simón } \\
\text { Arroyo en } \\
\text { Zelis) }\end{array}$ & $\begin{array}{l}\text { Matemático y científico. En } 1767 \text { era } \\
\text { sacerdote escolar en el Colegio de San } \\
\text { Ildefonso de Puebla de los Ángeles } \\
\text { (maestro previniente de Filosofía). } \\
\text { Reside en Roma (enterrado en la } \\
\text { parroquia de San Juan in Aino). }\end{array}$ & 15. & $\begin{array}{l}\text { Jesuita desde 10-VIII-1753. Secularizado. } \\
\text { "Imprimió: 1. Saggio teorico - aritmetico - } \\
\text { geometrico-astronomico - cronológico curioso; } 2 \text {. } \\
\text { Saggio matematico-critico-geometrico. Dejó } \\
\text { manuscritos: Sobre la educación y el modo fácil de } \\
\text { aprender la lengua latina, que envió a Madrid. } \\
\text { Asimismo dejó otros manuscritos sobre las } \\
\text { imposturas de médicos, abogados y curiales, y la } \\
\text { reforma de las leyes; y otro intitulado: El filosofo } \\
\text { dormido, que despierta algunas veces" (BJE, pp. } \\
\text { 109-110). }\end{array}$ & $\begin{array}{l}\text { *Jalapa, Puebla de los Ángeles, } \\
\text { 4-XI- 1734-†Roma, 12-VII- } \\
1787 .\end{array}$ \\
\hline $\begin{array}{l}{[276]} \\
\text { ARRIAGA } \\
\text { AGUILAR, } \\
\text { Blas Isidoro } \\
\text { de (2). MEX. }\end{array}$ & $\begin{array}{l}\text { Filólogo. En } 1767 \text { estaba en el Colegio } \\
\text { de San Javier de Puebla. Residió en el } \\
\text { antiguo colegio jesuítico de Tívoli. } \\
\text { Regresó a España entre } 1798 \text { y } 1801 \text {. }\end{array}$ & 5. & $\begin{array}{l}\text { Jesuita desde el 29-III-1753. Cuarto voto, el 2-II- } \\
\text { 1765. Su hermano José también fue jesuita } \\
\text { (coadjutor). "Cultivó con esmero el estudio de la } \\
\text { lengua mexicana". Misionero circular en Puebla. } \\
\text { Publicó en dos tomos, Biblioteca para misioneros } \\
\text { de naciones jentiles (BJE, p. 573). }\end{array}$ & $\begin{array}{l}\text { * Tlaxcala, 3-II-1729- } \\
\text { †Valencia, 12-II-1801. }\end{array}$ \\
\hline
\end{tabular}

\footnotetext{
${ }^{31}$ Sebastián, 1767-1796, vol. II: 93-95.
}

72 Antonio Astorgano Abajo y Fuensanta Garrido Domené. Panorama esquemático ... 60-120. 


\begin{tabular}{|c|c|c|c|c|}
\hline $\begin{array}{l}{[277]} \\
\text { ARRIOLA, } \\
\text { Juan (2). } \\
\text { MEX. }\end{array}$ & $\begin{array}{l}\text { Poeta y biógrafo. "Vivió por mucho } \\
\text { tiempo en el Colegio de San Luis de } \\
\text { Potosí". En } 1767 \text { era confesor en el } \\
\text { Colegio del Espíritu Santo en Puebla } \\
\text { de los Ángeles, donde falleció al año } \\
\text { siguiente. }\end{array}$ & 5. & $\begin{array}{l}\text { Jesuita desde 12-XI-1715. Cuarto voto 2-II-1733. } \\
\text { Escribió en verso español una Vida de Santa } \\
\text { Rosalía (BJE, p. 574), "en dulcísimas décimas, que } \\
\text { no se dieron a la estampa, mas las conservaban las } \\
\text { personas doctas en manuscritos, reconociéndola por } \\
\text { obra singular en su esfera, donde se leían juntas la } \\
\text { devoción y dulzura", según Félix de Sebastián }{ }^{32} \text {. }\end{array}$ & $\begin{array}{l}\text { *Santa Fe y Real de Minas de } \\
\text { Guanajato, 22-X-1698-†Puebla } \\
\text { de los Ángeles, 28-VIII-1768. }\end{array}$ \\
\hline $\begin{array}{l}\text { BAEGERT } \\
\text { [BEGERT] } \\
\text { SCHEIDECK, } \\
\text { Jaime (Juan } \\
\text { Jacobo, } \\
\text { Santiago) (4). } \\
\text { ALEMANIA } \\
\text { y MEX. }\end{array}$ & $\begin{array}{l}\text { Misionero en California y antropólogo, } \\
\text { historiador y naturalista de California. } \\
\text { "El año } 1767 \text { se hallaba misionero de } \\
\text { San Luis Gonzaga en la California". La } \\
\text { obra de Baegert, Noticias de la } \\
\text { península americana de California, ya } \\
\text { había sido publicada en Alemania y } \\
\text { había recibido buenas críticas, cuando } \\
\text { Clavigero redactó la suya (antes de } \\
\text { 1787), pero no pudo obtener un } \\
\text { ejemplar de la misma. En opinión de } \\
\text { Ronan, la obra de Clavigero superaba a } \\
\text { sus fuentes en exactitud, espíritu crítico } \\
\text { y acceso a materiales de primera } \\
\text { mano }\end{array}$ & 15. & $\begin{array}{l}\text { Hervás llega a la obra de Baegert a través de su } \\
\text { amigo Clavigero (BJE, p. 744). Jesuita desde } 27- \\
\text { IX-1736. Cuarto voto el 15-VIII-1754. "Escribió } \\
\text { en latín una Descripción de la California, la cual, } \\
\text { obra póstuma, en el } 1773 \text { se imprimió por Cristóbal } \\
\text { Murr en su obra: Journal zur Kunstgeschichte, \&c. } \\
\text { Núremberg (sic). } 12^{\circ} \text {. [...] De esta Historia de la } \\
\text { California, publicada por Berget, habla así } \\
\text { Clavigero, en la página } 15 \text { del primer volumen de } \\
\text { su Historia de la California, notada en el artículo } \\
\text { en esta Biblioteca [n } 50 \text { ]: "Jaime Bergert, alemán } \\
\text { que estuvo } 17 \text { años en California misionero, vuelto } \\
\text { a su patria, escribió en alemán una nueva Historia } \\
\text { de la California y la publicó en el 1772. Sabemos } \\
\text { que ha tenido grande aceptación" (BJE, pp. 743- } \\
744) \text {. }\end{array}$ & $\begin{array}{l}\text { *Sélestat (Bas-Rhin; Alsacia, } \\
\text { Francia, 22-XII- 1717- } \\
\text { †Neoburg, Neustadt (Hesse; } \\
\text { Alemania), 22-IX-1772. }\end{array}$ \\
\hline $\begin{array}{l}\text { [21] BELLIDO } \\
\text { SÁNCHEZ, } \\
\text { Josef (1). } \\
\text { ANDALUCÍA } \\
\text { y MEX. } \\
\text { Biografiado } \\
\text { por Maneiro. }\end{array}$ & $\begin{array}{l}\text { Teólogo. Reside en Bolonia. En } 1767 \\
\text { era admonitor, prefecto de estudios } \\
\text { mayores, consultor de casa y confesor } \\
\text { en el Colegio de San Ildefonso de } \\
\text { Puebla. (“Está sepultado en la } \\
\text { parroquia de S. Donato de Bolonia”). }\end{array}$ & 15. & $\begin{array}{l}\text { Jesuita desde 26-IV-1718. Sacerdote de cuarto voto } \\
\text { el 2-II-1735. Pasó a Nueva España en } 1723 \text {. } \\
\text { Desempeñó diversos cargos en Puebla, Oaxaca, } \\
\text { Guadalajara, Tepotzotlán y Zacatecas. Procurador a } \\
\text { las Cortes de Madrid y Roma. "Imprimió en } \\
\text { Méjico, por los años de 1756, la Vida de sor } \\
\text { Mariana Ágreda de San Ignacio, fundadora del } \\
\text { convento de S. Rosa en la Puebla de los Ángeles. }\end{array}$ & $\begin{array}{l}\text { *Granada (España), 22-VI- } \\
\text { 1700- †Bolonia, 17-XII-1783. }\end{array}$ \\
\hline
\end{tabular}

\footnotetext{
${ }^{32}$ Ibíd, 1767-1796, vol. I: 91-92.
}

${ }^{33}$ Ronan, 1977: 347. 


\begin{tabular}{|c|c|c|c|c|}
\hline & & & $\begin{array}{l}\text { En } 4^{\circ} \text { " }(B J E, \text { p. 132). Bellido había sido su director } \\
\text { espiritual }^{34} \text {. }\end{array}$ & \\
\hline $\begin{array}{l}{[29]} \\
\text { BORROTE, } \\
\text { Pedro (1). } \\
\text { MEX. } \\
\text { Biografiado } \\
\text { por el jesuita } \\
\text { Dionisio Pérez } \\
\left(\mathrm{n}^{\circ} 186\right) \text {. No } \\
\text { fue expulso. }\end{array}$ & $\begin{array}{l}\text { Operario y poeta. Enseñó retórica en el } \\
\text { Colegio de S. Pedro y S. Pablo de } \\
\text { México. Se dedicó enseguida a la } \\
\text { conversión de los indios y estuvo de } \\
\text { misionero en la mina de Mellado del } \\
\text { Real de Guanajuato. Murió durante una } \\
\text { epidemia, a causa de su dedicación } \\
\text { evangélica en el cuidado de los } \\
\text { enfermos. }\end{array}$ & 5. & $\begin{array}{l}\text { Jesuita desde } 1747 \text {. Cuarto voto. "Murió en } \\
\text { Juanajato el 1762, dejando ilustres ejemplos de } \\
\text { virtudes religiosas" (BJE, 139). Aunque Hervás no } \\
\text { cita ningún escrito suyo, está justificada su } \\
\text { inclusión dentro de la BJE, porque en la Biblioteca } \\
\text { Nacional de México se conserva un manuscrito } \\
\text { suyo intitulado Panegírico de la gloriosa muerte de } \\
\text { S. Ignacio de Loyola, compuesto de } 33 \text { octavas } \\
\text { reales, } 8 \text { liras y } 15 \text { décimas castellanas, de mucho } \\
\text { numen y gracia (ms. según Beristáin). }\end{array}$ & $\begin{array}{l}\text { *Guanajato (Mechoacán, } \\
\text { México) 1731-†Guanajuato, } \\
1762 .\end{array}$ \\
\hline $\begin{array}{l}\text { [32] BRITO, } \\
\text { Manuel (1). } \\
\text { MEX. }\end{array}$ & $\begin{array}{l}\text { Humanista y filósofo. En } 1767 \text { era } \\
\text { confesor en la residencia de Puerto } \\
\text { Príncipe. Residió en Bolonia. }\end{array}$ & 5. & $\begin{array}{l}\text { Jesuita desde } 13 \text {-VIII-1755. Cuarto voto, el 13-XI- } \\
\text { 1768. Publicó en Ferrara en } 1786 \text { el elogio fúnebre } \\
\text { de su paisano, también jesuita, José Vicente Anguas } \\
\text { y Alcocer (BJE, p. 140). }\end{array}$ & $\begin{array}{l}\text { *Mérida (Valladolid, según } \\
\text { Hervás) de Yucatán, 13-IX- } \\
\text { 1734-†Medecina (Italia), 29-V- } \\
1797 .\end{array}$ \\
\hline $\begin{array}{l}{[35]} \\
\text { CALATAYUD, } \\
\text { Nicolás (1). } \\
\text { MEX. No } \\
\text { llegó al } \\
\text { destierro }^{35} \text {. }\end{array}$ & $\begin{array}{l}\text { Orador. En } 1767 \text { era rector del Colegio } \\
\text { de Oaxaca. }\end{array}$ & 15. & $\begin{array}{l}\text { Jesuita desde 1-VII-1734. Cuarto voto, el 15-VIII- } \\
\text { 1747. "Imprimió: Oración fúnebre en las exequias } \\
\text { del Ilmo. señor D. Francisco Josef de Figueredo, } \\
\text { segundo Arzobispo de Guatemala. Manuscritos: } 1 . \\
\text { Arte poética española. } 2 \text {. Vida del jesuita Francisco } \\
\text { Javier Molina (BJE, p. 157-158). También } \\
\text { elogiaron al arzobispo Figueredo los jesuitas Rafael } \\
\text { Landívar y Juan Roset. }\end{array}$ & $\begin{array}{l}\text { *Minas de San Sebastián } \\
\text { (Guadalajara; México), 18-VI- } \\
\text { 1711-†Veracruz, 15-XI-1767. }\end{array}$ \\
\hline $\begin{array}{l}\text { [39] CAÑAS, } \\
\text { Bartolomé } \\
\text { José de (1). } \\
\text { MEX. }\end{array}$ & $\begin{array}{l}\text { Teólogo. En } 1767 \text { enseñaba Teología } \\
\text { Moral en el Colegio de San José de La } \\
\text { Habana. Residió en Bolonia. Falleció } \\
\text { en la parroquia de San Barbaciano de } \\
\text { Bolonia, pero "está sepultado en la } \\
\text { iglesia de la Virgen Santísima de la } \\
\text { Nieve, en la cual había colocado la }\end{array}$ & 15. & $\begin{array}{l}\text { Jesuita desde 1-III-1749. Cuarto voto el 2-II-1765. } \\
\text { "Imprimió: 1. Novena di ossequi in apparecchio } \\
\text { alla festa di Maria V. Madre Santíssima del Lume. } \\
\text { Bologna, 1777. 2. Breve noticia della sacra } \\
\text { imagine della Madre Santissima del Lume, e del } \\
\text { suo glorioso titolo, \&c. Bologna, 1781. E1 autor } \\
\text { dejó manuscritas algunas obras de devoción" (BJE, }\end{array}$ & $\begin{array}{l}* \text { San Vicente (Guatemala), } 24- \\
\text { VIII-1729- †Bolonia, 4-XII- } \\
1787 .\end{array}$ \\
\hline
\end{tabular}

\footnotetext{
${ }^{34}$ Sebastián, 1767-1796, vol. I: 465-466.
}

${ }^{35}$ Ibíd., 1767-1796, vol. I: 40-42. 


\begin{tabular}{|c|c|c|c|c|}
\hline & $\begin{array}{l}\text { imagen de la Virgen Santísima con el } \\
\text { título de la Luz, fabricándole altar y } \\
\text { dándole fiesta anual” (BJE, p. 167). }\end{array}$ & & $\begin{array}{l}\text { p. 167). Ciertamente dedicó todas sus fuerzas a } \\
\text { difundir la devoción a esta Virgen, como destacan } \\
\text { el P. Luengo }{ }^{36} \text { y Félix de Sebastián en su amplia } \\
\text { reseña mortuoria }{ }^{37} \text {. }\end{array}$ & \\
\hline $\begin{array}{l}{[291]} \\
\text { CARRILLO } \\
\text { MALDONADO, } \\
\text { Josef (2). } \\
\text { MEX. }\end{array}$ & $\begin{array}{l}\text { Moralista. En } 1767 \text { era consultor de } \\
\text { casa y confesor en el Colegio de San } \\
\text { Andrés de México. Residió en Bolonia. } \\
\text { "Al pasar el señor Carrillo, cuando era } \\
\text { jesuita, por Parma, por orden de su } \\
\text { ministerio dejó depositado el baúl de } \\
\text { sus libros, escritos, \&c., y le quitaron el } \\
\text { dicho tomo" (BJE, p. 584). Está } \\
\text { enterrado en la parroquia de San Juan } \\
\text { del Monte de Bolonia (C. 174) })^{38} \text {. }\end{array}$ & 10 . & $\begin{array}{l}\text { Jesuita desde } 25 \text {-III-1720. Cuarto voto el 2-II-1735. } \\
\text { "Escribió obras espirituales y, entre ellas, un tomo } \\
\text { grande sobre los Ejercicios espirituales de San } \\
\text { Ignacio para uso y utilidad de los que los hacian en } \\
\text { la dicha casa de Méjico" (BJE, p. 584). }\end{array}$ & $\begin{array}{l}\text { * Maravatío de Michoacán, 1- } \\
\text { XI-1700- †Bolonia, 6-XII-1774. }\end{array}$ \\
\hline $\begin{array}{l}\text { [295] [PÉREZ } \\
\text { DE] CASTRO Y } \\
\text { TEMBRA, } \\
\text { Agustín Pablo } \\
\text { de (2). MEX. } \\
\text { Biografiado } \\
\text { por Maneiro. }\end{array}$ & $\begin{array}{l}\text { Poeta y biógrafo. Reside en Bolonia. } \\
\text { En } 1767 \text { se hallaba sin destino } \\
\text { (operario) en la Casa Profesa de } \\
\text { México. Residió en Ferrara y Bolonia, } \\
\text { donde fue superior de casas jesuitas. } \\
\text { Hermano de los jesuitas Joaquín y } \\
\text { Miguel Ignacio. Enseñó también } \\
\text { tipografía. Conocedor del alemán, el } \\
\text { francés, el inglés, el italiano, el latín y } \\
\text { el griego, enseñó humanidades en } \\
\text { Italia. Llegó a ser rector de los jesuitas } \\
\text { en Ferrara, donde vivió } 23 \text { años. Fue el } \\
\text { consultor y censor privado de los } \\
\text { jesuitas americanos que escribieron } \\
\text { o publicaron. "Está sepultado en la } \\
\text { parroquial de San Juan in Monte de }\end{array}$ & 10 . & $\begin{array}{l}\text { Suscriptor a la enciclopedia de Idea dell'Universo. } \\
\text { Jesuita desde 15-I-1746. Cuarto voto el 15-V-1763. } \\
\text { Escribió sobre Campoy, Clavigero y Alegre. } \\
\text { Operario en Veracruz y Casa Profesa; maestro de } \\
\text { latín en Oaxaca, de Filosofía en Querétaro; } \\
\text { vicerrector en la ciudad de México. Según F. } \\
\text { Sebastián, fue llamado por el obispo de Valladolid } \\
\text { "para un negocio importante"39. Prefecto de } \\
\text { congregación en Guadalajara; operario en } \\
\text { Tepotzotlán. Fue el primer maestro de la cátedra de } \\
\text { Derecho Canónico en Mérida de Yucatán. } \\
\text { "Escribió: 1. Fábulas de Fedro. En verso español } \\
\text { con notas. 2. La Hernandia o conquista de Méjico } \\
\text { por Hernán Cortés. En verso heroico español. } 3 . \\
\text { Traducción de algunas trajedias de Séneca, en } \\
\text { verso español. } 4 \text {. Diez opúsculos de materias } \\
\text { sagradas eruditas, escritos en Ferrara desde el } 1769\end{array}$ & $\begin{array}{l}\text { * Córdoba de México } \\
\text { (Veracruz), 24-I-1728- } \\
\text { †Bolonia, 23-XI-1790. }\end{array}$ \\
\hline
\end{tabular}

\footnotetext{
${ }^{36}$ Luengo, Diario, día 5.7.1779.

${ }^{37}$ Sebastián, 1767-1796, vol. II: 92.

${ }^{38}$ Ibíd., 1767-1796, vol. I: 245-248.

${ }^{39}$ Ibíd., 1767-1796, vol. II: 175-179.
} 


\begin{tabular}{|c|c|c|c|c|}
\hline & Bolonia" (Libro, D. 100). & & $\begin{array}{l}\text { hasta el } 1773 \text { sobre los problemas que se proponían } \\
\text { y premiaban en la que fue provincia jesuítica de } \\
\text { Aragón, establecida en Ferrara" (BJE, p. 587). }\end{array}$ & \\
\hline $\begin{array}{l}\text { [45] CAVO } \\
\text { ALCARAZ, } \\
\text { Andrés de (1). } \\
\text { MEX. }\end{array}$ & $\begin{array}{l}\text { Humanista e historiador. En } 1767 \text { era } \\
\text { misionero en Nayarit (Santísima } \\
\text { Trinidad). Secularizado en } 1769 \text { en el } \\
\text { Puerto de Santa María. Residió en } \\
\text { Roma. Regresó a España entre } 1798 \text { y } \\
1801 .\end{array}$ & 5. & $\begin{array}{l}\text { Jesuita desde 14-I-1758. Su hermano Lorenzo } \\
\text { también fue jesuita (fallecido en México el 3-III- } \\
\text { 1803). Maestro de gramática y de aposentos en } \\
\text { Guanajuato y Puebla. Escribió la vida de su } \\
\text { maestro José Julián Parreño, en latín (Roma, 1792) } \\
\text { (BJE, p. 177). Más patriota que seguidor de San } \\
\text { Ignacio, escribirá posteriormente unos Anales de la } \\
\text { ciudad de México desde la conquista española } \\
\text { hasta el año de 1766, donde arremete contra "el } \\
\text { yugo de los españoles"40. }\end{array}$ & $\begin{array}{l}\text { * Guadalajara (México) 13-II- } \\
1739-\dagger \text { Roma, 23-X-1803. }\end{array}$ \\
\hline $\begin{array}{l}{[50]} \\
\text { CLAVIGERO } \\
\text { ECHEGARAY, } \\
\text { Francisco } \\
\text { Javier (1). } \\
\text { MEX. Íntimo } \\
\text { amigo de } \\
\text { Hervás. } \\
\text { Elogio fúnebre } \\
\text { por Agustín } \\
\text { Pablo de } \\
\text { Castro (n } \\
\text { 295) y } \\
\text { biografiado } \\
\text { por Maneiro } \\
\text { (nº. 133), que } \\
\text { sigue siendo la } \\
\text { fuente más } \\
\text { completa, a la }\end{array}$ & $\begin{array}{l}\text { Historiador y pedagogo. En } 1767 \text { era } \\
\text { profesor de filosofía y prefecto de } \\
\text { congregación en Guadalajara. Residió } \\
\text { en Ferrara y en Bolonia, ya en } 1773 \text {. } \\
\text { "Le traté personalmente diez y ocho } \\
\text { meses continuos, y ocho años por } \\
\text { carteo amigable, y siempre le encontré } \\
\text { igual en la honradez, rectitud, agudeza } \\
\text { y universidad de su pensar religioso y } \\
\text { docto }{ }^{41} \text {. Luego que en Italia se dio a } \\
\text { conocer con sus públicas producciones, } \\
\text { llamó la atención y la estimación de los } \\
\text { literatos europeos, entre los que se } \\
\text { distinguió el erudito conde Rinaldo } \\
\text { Carli en honrarle de todos modos; y los } \\
\text { doctores de la esclarecida universidad } \\
\text { de Méjico le escribieron dándole } \\
\text { sinceras pruebas que, justísimamente, } \\
\text { hacían de las raras prendas de un sabio }\end{array}$ & $\begin{array}{l}\text { Muy } \\
\text { Importante }\end{array}$ & $\begin{array}{l}\text { Suscriptor (¿también su hermano?) a la } \\
\text { enciclopedia de Idea dell'Universo. Jesuita desde } \\
\text { 13-II-1748. Cuarto voto el 2-II-1765. Fue } \\
\text { presidente de las academias teológicas en el San } \\
\text { Ildefonso de México. Aprendió la lengua mexicana. } \\
\text { Maestro de Filosofía en Valladolid y Guadalajara. } \\
\text { "Habiéndose aprovechado de la educación } \\
\text { científica que en su niñez le procuraron sus nobles } \\
\text { padres. [...] Habiendo concluido sus estudios } \\
\text { filosóficos y teológicos en los que cultivó el de las } \\
\text { lenguas eruditas y de las ciencias físicas [...] Poseía } \\
\text { eminentemente las lenguas española, mejicana, } \\
\text { latina e italiana y más que medianamente la } \\
\text { francesa y la griega. Vivió siempre en retiro } \\
\text { aprendiendo a ser virtuoso y docto, lo que con } \\
\text { excelencia consiguió: Su trato era civil, honrado, } \\
\text { nobilísimo, docto y santo [...] Imprimió: } 1 . \text { Storia } \\
\text { antica del Messico cavata da'migliori storici } \\
\text { spagnuoli, e da'manoscritti, e dalle pitture antiche }\end{array}$ & $\begin{array}{l}\text { * Veracruz, 9-IX-1731- } \\
\text { †Bolonia, 2-IV-1787 (56 años, } \\
\text { Santos Cosme y Damián, pero } \\
\text { sepultado en Santa Lucía, I. a. } \\
\text { d.). }\end{array}$ \\
\hline
\end{tabular}

${ }^{40}$ Saint Clair Segurado, 2005: 341.

${ }^{41}$ Se conserva abundante correspondencia enviada por Clavigero desde Bolonia a Hervás, residente en Cesena entre los años 1780 y 1786 , reseñada por Batllori, 1966: 256-258.

76 Antonio Astorgano Abajo y Fuensanta Garrido Domené. Panorama esquemático ... 60-120. 


\begin{tabular}{|c|c|c|c|c|}
\hline $\begin{array}{l}\text { que recurre } \\
\text { casi toda la } \\
\text { bibliografía. }\end{array}$ & $\begin{array}{l}\text { tan insigne. }[\ldots] \text { Habiendo padecido } \\
\text { una larga y penosísima enfermedad, en } \\
\text { que dio continuos y heroicos ejemplos } \\
\text { de virtud, abreviada su vida por sus } \\
\text { tareas literarias, pasó a los eternos } \\
\text { reposos. Yace en la iglesia de Santa } \\
\text { Lucía" (BJE, p. 187). Restos } \\
\text { trasladados a México en agosto de } \\
1970 .\end{array}$ & & $\begin{array}{l}\text { degl' indiani. Cesena. Per Gregorio Biasini, } 1780.4 \\
\text { tomos. } 2 \text {. Breve ragguaglio della prodigiosa et } \\
\text { rinomata imagine della Madonna di Guadalupe del } \\
\text { Messico. Cesena, 1782. Per Gregorio Biasini, } 8 .{ }^{\circ} \text {. } \\
\text { Obra anónima. 3. Storia della California: opera } \\
\text { postuma del nobile signor abate D. Francesco } \\
\text { Saverio Clavigero. Venezia, 1789, volúms. } 2 . \\
\text { Dejó manuscritas las obras siguientes: } 1 . \text { La } \\
\text { historia eclesiástica y geográfica del reino de } \\
\text { Méjico. Esta obra quedó imperfecta }{ }^{42} .3 \text {. } \\
\text { Conversación entre Filaleto y Paleófilo sobre el } \\
\text { estudio de la física. } 4 \text {. El sacerdote instruido en los } \\
\text { ministerios de confesar y predicar. Sé que, además } \\
\text { de estas obras, el señor Clavigero había escrito } \\
\text { algunas en latín y otras había traducido del griego, } \\
\text { del latín y del francés. Del señor Clavigero hacen } \\
\text { varios autores honorífica mención, y yo varias } \\
\text { veces la he hecho en mis obras en que registré el } \\
\text { día triste de su muerte" (BJE, pp. 185-189) }{ }^{43} \text {. }\end{array}$ & \\
\hline $\begin{array}{l}\text { [302] CoTE } \\
\text { MuÑOZ (otros, } \\
\text { Muñoz Cote), } \\
\text { Manuel (2). } \\
\text { MEX. }\end{array}$ & $\begin{array}{l}\text { Lingüista. En } 1767 \text { era teólogo de } \\
\text { cuarto año en el Colegio Máximo de } \\
\text { México. Residió en Bolonia. Regresó a } \\
\text { España entre } 1798 \text { y } 1801 \text {. }\end{array}$ & 5. & $\begin{array}{l}\text { Corresponsal de Hervás. Jesuita desde 27-II-1757. } \\
\text { Cuarto voto el 2-II-1773. "Escribió: Istituzioni } \\
\text { gramaticali della lingua latina" (BJE, p. 590). }\end{array}$ & $\begin{array}{l}\text { *Appa (México), 21-VIII-1739- } \\
\dagger \text { Roma, 8-II-1811. }\end{array}$ \\
\hline $\begin{array}{l}\text { [486] DUCRUE } \\
\text { LUDWIG, } \\
\text { Franz Benno } \\
\text { (4). } \\
\text { ALEMANIA } \\
\text { y MEX. }\end{array}$ & $\begin{array}{l}\text { Misionero en California (Guadalupe) y } \\
\text { cronista de la expulsión. En } 1767 \text { era } \\
\text { Visitador de las misiones de California. }\end{array}$ & 10 & $\begin{array}{l}\text { Jesuita desde 28-IX-1738. Cuarto voto el 2-II-1756. } \\
\text { "Escribió la expulsión de los jesuitas de California, } \\
\text { que se publicó por Cristóbal Murr con este título: } \\
\text { Relatio expulsionis Societatis Jesu ex provincia } \\
\text { mexicana, et maxime e California. Anno 1767, cum } \\
\text { aliis scitu dignis notiatis scripta a P. Bennone } \\
\text { Francisco Ducrue ejusdem provinciae per viginti }\end{array}$ & $\begin{array}{l}\text { * Mannheim (Munich, Baviera), } \\
\text { 10-VI-1721- †Múnich, 30-III- } \\
\text { 1779. }\end{array}$ \\
\hline
\end{tabular}

${ }_{42}^{42}$ Hervás tuvo cierta participación en este manuscrito, a juzgar por la noticia que da sobre el mismo en 1789 en el volumen II de la Historia de la vida del hombre (p. 243, nota 2): "El autor [Clavigero] un año antes de morir [1787] me avisó que tenía casi concluida la Historia geográfica y eclesiástica de México, que a instancias mías había escrito".

${ }^{43}$ Sebastián, 1767-1796, vol. II: 61-68; Quiñones Melgoza, 2005: 378-379.

77 Antonio Astorgano Abajo y Fuensanta Garrido Domené. Panorama esquemático ... 60-120. 


\begin{tabular}{|c|c|c|c|c|}
\hline & & & $\begin{array}{l}\text { annos missionario. Véase: Christoph. Gottlieb von } \\
\text { Murr journal zur Kunstgeschichte, und zur } \\
\text { allgemeinen litteratur. Nurnberg. } 1784.12^{\circ} \text {. En el } \\
\text { volumen } 12 \text {, desde la página } 217 \text { hasta la página } \\
\text { 275. En la página } 268 \text {, Murr pone algunas noticias } \\
\text { de Ducrue sobre la lengua california y dice: } \\
\text { "Muchas más daré en mi Biblioteca glótica } \\
\text { universal" (BJE, pp. } 750-751)^{44} \text {. }\end{array}$ & \\
\hline $\begin{array}{l}{[306]} \\
\text { FÁBREGA } \\
\text { BUSTAMANTE, } \\
\text { Lino Josef (2). } \\
\text { MEX. }\end{array}$ & $\begin{array}{l}\text { Historiador. Reside en Roma. En } 1767 \\
\text { estaba en Tepotzotlán haciendo el } \\
\text { noviciado, siendo de los pocos novicios } \\
\text { que llegó a Italia e hizo los votos, si } \\
\text { bien se secularizó el 11-XI-1771. Tras } \\
\text { la extinción se retiró a Roma, donde } \\
\text { contó con la protección del cardenal } \\
\text { Stefano Borgia, Prefecto de la } \\
\text { Propaganda Fidei, para dedicarse al } \\
\text { estudio de las antigüedades mexicanas. } \\
\text { La BJE no recoge su obra más } \\
\text { importante y relevante para el estudio } \\
\text { de la cultura náhuatl, Esposizione del } \\
\text { codice borgiano, premessa una breve } \\
\text { notizia degli originali esistenti in } \\
\text { Europa di altri codici citati dagli } \\
\text { autori e delle copie pubblicate o } \\
\text { inedite come ancora alcune } \\
\text { osservazioni su i sogetti essenziali del } \\
\text { calendario messicano per la di lui } \\
\text { migliore intelligenza (México, } \\
\text { 1891-1900), y un Mapa de las misiones } \\
\text { que tenia la provincia de la Compañia } \\
\text { de Jesús de México, con sus } \\
\text { correspondientes notas y } \\
\text { declaraciones, manuscrito perdido en }\end{array}$ & 10 & $\begin{array}{l}\text { Jesuita desde } 12 \text { (Hervás, 12)-IV-1766. } \\
\text { Colaborador de Hervás y suscriptor a la } \\
\text { enciclopedia Idea dell'Universo. En la BJE (p. 592) } \\
\text { se anotan dos manuscritos: "l. Vocabolario } \\
\text { geografico, storico, naturale, civile, ed } \\
\text { ecclesiastico de'domini spagnuoli nell'América } \\
\text { settentrionale. El autor, desistiendo de imprimir } \\
\text { esta obra en italiano, la traduce en español. } 2 . \\
\text { Disertaciones sobre la antigua historia mejicana. } \\
\text { Anuncié esta obra en la página } 243 \text { de mi segundo } \\
\text { tomo de la Historia del Hombre, impresa en Madrid } \\
\text { en } 1789 \text {. El autor, hasta ahora, no ha podido } \\
\text { publicar ninguna producción suya, porque } \\
\text { continuadas desgracias le han impedido conseguir } \\
\text { el dinero propio que tenía destinado para la } \\
\text { impresión". En la citada página } 243 \text { del tomo } \\
\text { segundo de La historia del hombre, se lee: "El } \\
\text { señor abate Joseph Fábrega escribe actualmente } \\
\text { disertaciones excelentes sobre la historia antigua de } \\
\text { los mexicanos". Más adelante alaba al historiador } \\
\text { Fábrega, informante personal ("me ha dicho"), al } \\
\text { estudiar la afinidad de las lenguas pima y } \\
\text { sobaipuri }{ }^{45} \text {. }\end{array}$ & $\begin{array}{l}\text { *Tegucigalpa, } 22 \text { (Hervás, } \\
\text { 23)-IX-1746- †Vitorchiano } \\
\text { (Viterbo; otros Roma), } \\
20-\mathrm{V}-1797 .\end{array}$ \\
\hline
\end{tabular}

\footnotetext{
${ }^{44}$ Ducrue había embarcado para México el 16 de junio de 1750. Sacerdote en Munich desde 1769, envió el manuscrito a Murr el 27 de agosto de 1778. ${ }^{45}$ Hervás, 1800: 341.
} 


\begin{tabular}{|c|c|c|c|c|}
\hline & la actualidad. & & & \\
\hline $\begin{array}{l}{[70] \text { FABRI }} \\
\text { DOMÍNGUEZ, } \\
\text { Manuel (1). } \\
\text { MEX. }\end{array}$ & $\begin{array}{l}\text { Biógrafo. Reside en Bolonia. En } 1767 \\
\text { estudiaba humanidades en Tepotzotlán, } \\
\text { donde, ya sacerdote, era "maestro de } \\
\text { nuestros escolares en letras humanas y } \\
\text { consultor de la casa". Residente en } \\
\text { Bolonia en } 1773 \text {. Regresó a España } \\
\text { entre } 1798 \text { y } 1801 .\end{array}$ & 10. & $\begin{array}{l}\text { Jesuita desde 31-I-1754. Cuarto voto en Bolonia, 2- } \\
\text { II-1771. Amigo del helenista catalán Bartolomé } \\
\text { Pou (n. }{ }^{\circ} 198 \text { de la BJE). "Imprimió: 1. La vida del } \\
\text { señor Abad la cual con el título Specimen vitae } \\
\text { auctoris se halla en la edición del poema de [Diego } \\
\text { Josef] Abad, intitulado De Deo, e impreso en } \\
\text { Cesena, 1780, y cuidó recoger las obras del dicho } \\
\text { [Diego Josef] Abad que al dicho poema se } \\
\text { añadieron en su tercera edición, que es la citada, en } \\
\text { Cesena. 2. La vida del señor Alegre, que con el } \\
\text { título De auctoris vita commentarius se halla en el } \\
\text { primer tomo de las Instituciones teológicas de } \\
\text { Alegre, impresas en Venecia, 1789" (BJE, pp. 223- } \\
\text { 224). }\end{array}$ & $\begin{array}{l}\text { *México, 18-XI-1737- } † \text { Roma, } \\
\text { 17-III-1805. }\end{array}$ \\
\hline $\begin{array}{l}\text { [76] FUENTE } \\
\text { BOCANEGRA, } \\
\text { Andrés Diego } \\
\text { de la (1). } \\
\text { MEX. }\end{array}$ & $\begin{array}{l}\text { Humanista. Capellán de una hacienda } \\
\text { en Querétaro en } 1767 \text {. Residió en } \\
\text { Bolonia, donde falleció, a los } 78 \text { años y } \\
\text { está enterrado en la Parroquia de San } \\
\text { Donato (Libro VII, } 7)^{46} \text {. }\end{array}$ & 5. & $\begin{array}{l}\text { Jesuita desde 30-VI-1723. Sacerdote de cuarto voto, } \\
\text { el 8-XII-1740. "Imprimió: Andreas Didacus } \\
\text { Fontanus: Guadalupana B. Virginis imago, quae } \\
\text { Mexici colitur carmine descripta. Faventiae, } 1773 . \\
\text { Ex typographia Jos. Antonii Archii", es decir } \\
\text { Descripción poética de la Virgen Guadalupana" } \\
\text { (BJE, pp. 232-233). }\end{array}$ & $\begin{array}{l}\text { * San Luis de Potosí (México), } \\
\text { 9-XII-1705- †Bolonia, 26-III- } \\
\text { 1783. }\end{array}$ \\
\hline $\begin{array}{l}{[78]} \\
\text { GALLARDO, } \\
\text { Pedro María } \\
\text { (otros Pedro } \\
\text { Antonio) (1) } \\
\text { MEX. }\end{array}$ & $\begin{array}{l}\text { Poeta latino, himnógrafo y biógrafo. En } \\
1767 \text { estaba "inválido" en el Colegio } \\
\text { del Espíritu Santo de Puebla. Residió } \\
\text { en Ferrara. "Sus costumbres eran } \\
\text { evangélicas y su estudio era siempre de } \\
\text { ciencias sagradas, que formaban las } \\
\text { delicias de su espíritu y de su genio" } \\
(B J E, \text { p. } 234)^{47} \text {. }\end{array}$ & 15. & $\begin{array}{l}\text { Jesuita desde 19-II-1750. “Cultivó con particular } \\
\text { esmero la ciencia de ritos sagrados y la poesía } \\
\text { latina, de la que hizo gran uso en himnos sagrados. } \\
\text { Imprimió: 1. En la ciudad de Faenza [1773], } \\
\text { Himnos y odas latinas en honor de la Beatísima } \\
\text { Virgen María de Guadalupe de Méjico, de S. Felipe } \\
\text { de Jesús, \&c. De sus obras impresas he visto la } \\
\text { siguiente: } 2 \text {. Conspicui sanctitatis fama mexicani }\end{array}$ & $\begin{array}{l}\text { *Aguascalientes (México), 17- } \\
\text { VII-1736 - †Ferrara, 15-III- } \\
1786 \text { (Hervás, 15-VIII-1785). }\end{array}$ \\
\hline
\end{tabular}

${ }^{46}$ Sebastián, 1767-1796, vol. I: 444-446.

${ }^{47}$ F. de Sebastián añade que ya en México "le flaqueaba la cabeza, y prorrumpía en algunos despropósitos no coordinados". Con la fantasía descompuesta, en el destierro se ocupó en escribir cosas santas, ya en verso latino ya en prosa, "y particularmente los elogios de la Santísima Virgen en su prodigiosa imagen de Guadalupe, de que dio varias cosas a la imprenta; como del Santo mártir mexicano Felipe de Jesús, ya dando a la luz varios oficios y rezos de 


\begin{tabular}{|c|c|c|c|c|}
\hline & & & $\begin{array}{l}\text { compendio nominantur a Pedro María Gallardo, } \\
\text { mexicano. Faventiae, ex typographia Josephi } \\
\text { Antonii Archii, } 1777,4^{\circ} .3 \text {. Asimismo imprimió: } \\
\text { De imagine Guadalupensi mexicana yambico- } \\
\text { archilochii, \&c, Josephi Adriani Mondregón. } \\
\text { Ibídem, } 1774.4^{\circ} \text {. Quizá el señor Gallardo se } \\
\text { llamaba Mondregón de segundo apellido. } \\
\text { Manuscritos: } 1 \text {. Decretos selectos de sagrados } \\
\text { ritos. Un tomo. } 2 \text {. De vita Ven. P. Petri Fabri, Soc. } \\
\text { Iesu. } 3 . \text { Hymni Sacri CC. in honorem B. V. Mariae } \\
\text { et Sanctorum, \&c." (BJE, p. 234). }\end{array}$ & \\
\hline $\begin{array}{l}{[80]} \\
\text { GANANCIA DE } \\
\text { LEÓN, } \\
\text { Francisco (1). } \\
\text { MEX. }\end{array}$ & $\begin{array}{l}\text { Orador y poeta, émulo de Calderón de } \\
\text { la Barca. Residió en Roma. En octubre } \\
\text { de } 1747 \text { organizó en Guadalajara las } \\
\text { honras fúnebres de Felipe } \mathrm{V}^{48} \text {. En } 1767 \\
\text { estaba en el Colegio de Querétaro, } \\
\text { donde era "prefecto del catecismo". } \\
\text { "En Italia vivió siempre con salud } \\
\text { achacosa en el mayor retiro, dando } \\
\text { diariamente algunas horas a la santa } \\
\text { meditación; y su escrupulosa } \\
\text { religiosidad le ocasionó la última } \\
\text { enfermedad de pulmonía [...] y está } \\
\text { sepultado en la iglesia de S. Salvador } \\
\text { in campo de Roma" (BJE, p. 238). }\end{array}$ & 15. & $\begin{array}{l}\text { Amigo de José Julián Parreño. Jesuita desde 26-VI- } \\
1742 \text {. Cuarto voto el 2-II-1757. Secularizado en el } \\
\text { Puerto de Santa María. "Cultivó la poesía española } \\
\text { y latina, en que era eminente. Y de sus } \\
\text { producciones poéticas se imprimieron algunas, } \\
\text { como las elegantes que, por encargo de la ciudad de } \\
\text { Méjico, publicó en las Exequias de María Bárbara, } \\
\text { reina de España. Imprimió las poesías antes } \\
\text { citadas. Manuscritos: 1. Algunos tomos de } \\
\text { panejíricos y sermones morales. 2. Diversas obras } \\
\text { poéticas. Estos manuscritos dejó el autor en } \\
\text { América" (BJE, p. 238). }\end{array}$ & $\begin{array}{l}\text { *Ciudad de México, 5-XI-1723- } \\
\dagger \text { Roma, 7-I-1775. }\end{array}$ \\
\hline $\begin{array}{l}\text { [94] GONDRA, } \\
\text { Josef Mariano } \\
\text { de (1). MEX. } \\
\text { Usó el } \\
\text { seudónimo de } \\
\text { "José Adrián }\end{array}$ & $\begin{array}{l}\text { Poeta latino e italiano. Residió en } \\
\text { Ferrara. Operario en la Casa Profesa en } \\
\text { 1767. "Se aplicó con particular esmero } \\
\text { a la poesía latina e italiana, en la que ha } \\
\text { hecho muchas composiciones, que se } \\
\text { hallan impresas en diversas colecciones }\end{array}$ & 15. & $\begin{array}{l}\text { Suscriptor a la enciclopedia de Idea dell'Universo. } \\
\text { Jesuita desde 25-II-1752. Cuarto voto en Ferrara el } \\
\text { 2-II-1772 (Hervás, 1773). Imprimió: En la ciudad } \\
\text { de Faenza en versos latinos yámbicos la } \\
\text { Descripción de la imagen de la Virgen Santísima de } \\
\text { Guadalupe de Méjico [Faenza, 1774]. Y, en Ferrara }\end{array}$ & $\begin{array}{l}\text { *México, 8-IX-1737- †Ferrara, } \\
\text { 17-IV-1784. }\end{array}$ \\
\hline
\end{tabular}

nuestros santos españoles, para que en todos se conservara la memoria y veneración de aquellos santos, bajo cuyo patrocinio había nacido". Sebastián, 1767-1796, vol. II: 3-6.

${ }^{48}$ Zambrano, 1966, tomo xv: 645-646.

80 Antonio Astorgano Abajo y Fuensanta Garrido Domené. Panorama esquemático ... 60-120. 


\begin{tabular}{|c|c|c|c|c|}
\hline Madregón". & $\begin{array}{l}\text { poéticas" ( } B J E, \text { p. } 252) \text {, cualidades } \\
\text { reseñadas por Sebastián }{ }^{49} \text {. }\end{array}$ & & $\begin{array}{l}\text { [1773], imprimió en latín epigramas, un poema, y } \\
\text { una elegía en honor de 1a fiesta de la Virgen } \\
\text { Santísima de los Dolores. Cuando murió tenía } \\
\text { escritos, preparados para la impresión, una égloga } \\
\text { latina, un poema heroico de Santa Margarita de } \\
\text { Cortona y un Horacio cristiano. Asimismo, dejó } \\
\text { manuscritas las dos obras siguiente: 1. Poesías } \\
\text { latinas en honor de la Virjen Santísima de } \\
\text { Guadalupe de Méjico. 2. Traducción italiana del } \\
\text { libro que, sobre la imagen de la Virjen Santísima } \\
\text { de Guadalupe, escribió el famoso pintor Miguel } \\
\text { Cabrera" (BJE, p. 252). }\end{array}$ & \\
\hline $\begin{array}{l}{[320]} \\
\text { GONZÁLEZ } \\
\text { CANTABRANA, } \\
\text { Manuel (2). } \\
\text { MEX. }\end{array}$ & $\begin{array}{l}\text { Humanista y poeta latino. En } 1767 \\
\text { estaba en el Seminario de Guatemala } \\
\text { (el rector era Rafael Landívar), donde } \\
\text { era maestro de Filosofía y de } \\
\text { aposentos. Reside en Roma. }\end{array}$ & 5. & $\begin{array}{l}\text { Jesuita desde 5-X-1754. Secularizado en Ajaccio en } \\
1768 \text {. Fue otro de los jesuitas que publicó un elogio } \\
\text { fúnebre en honor del arzobispo de Guatemala } \\
\text { Francisco José Figueredo. "Escribió: } 1 . \\
\text { Humaniorum litterarum rudimenta. I. Rhetorices. } \\
\text { II. Poeseos. III. Lapidariae. 2. De promisso } \\
\text { hominibus Mesia per VI mundi aetates, patribus } \\
\text { expectatum. Carmen" (BJE, p. 602). }\end{array}$ & $\begin{array}{l}\text { * Guanajuato, 3-X-1736- } \\
\dagger \text { Poggio Mirteto, 10-XII-1797. }\end{array}$ \\
\hline $\begin{array}{l}{[322]} \\
\text { GONZÁLEZ DE } \\
\text { ANDA, Juan } \\
\text { Ignacio (2). } \\
\text { MEX. } \\
\text { Hermano del } \\
\text { también } \\
\text { jesuita y } \\
\text { escritor } \\
\text { Narciso } \\
\text { González. }\end{array}$ & $\begin{array}{l}\text { Biógrafo. Devoto de la Virgen de } \\
\text { Guadalupe. Reside en Bolonia. En } \\
1767 \text { era prefecto de Iglesia y cárceles } \\
\text { en la Casa Profesa de México. } \\
\text { Residente en Bolonia en 1773, } \\
\text { acompañado de su hermano Andrés. } \\
\text { Félix de Sebastián confirma } \\
\text { plenamente su devoción guadalupana }{ }^{50} .\end{array}$ & 10. & $\begin{array}{l}\text { Jesuita desde 23-VIII-1753. Cuarto voto, el 2-II- } \\
\text { 1765. Tras estudiar Filosofía y Teología quiso } \\
\text { entrar en la Orden, pero sus padres eran ancianos y } \\
\text { tenía muchos hermanos de poca edad. "En Bolonia } \\
\text { promovió celosamente la devoción a la Virgen } \\
\text { Santísima con el título de Guadalupe de Méjico; le } \\
\text { fabricó un altar dotando la fiesta anual en la } \\
\text { parroquia de Santa Catalina mártir, en la que fue } \\
\text { sepultado. Escribió las vidas del religiosísimo } \\
\text { jesuita Francisco Zevallos [provincial reformista, no } \\
\text { 438], y de otros ex jesuitas mejicanos" (BJE, p. } \\
603) \text {. }\end{array}$ & $\begin{array}{l}\text { *Teocaltiche (Guadalajara), } \\
6-\mathrm{I}-1724)-\dagger \text { Bolonia, } \\
\text { 28-IX-1792. }\end{array}$ \\
\hline
\end{tabular}

\footnotetext{
${ }^{49}$ Sebastián, 1767-1796, vol. I: 483-485.

${ }^{50}$ Ibíd., 1767-1796, vol. II: 227.
} 


\begin{tabular}{|c|c|c|c|c|}
\hline $\begin{array}{l}{[323]} \\
\text { GONZÁLEZ DE } \\
\text { ANDA, } \\
\text { Narciso (2). } \\
\text { MEX. } \\
\text { Hermano de } \\
\text { Juan Ignacio. }\end{array}$ & $\begin{array}{l}\text { Latinista y matemático. Residió en } \\
\text { Bolonia. En } 1767 \text { estaba en el Colegio } \\
\text { del Espíritu Santo de Puebla, } \\
\text { realizando la tercera probación. "Se } \\
\text { aplicó con particular esmero a la } \\
\text { latinidad y a las matemáticas, y se } \\
\text { ejercitó con aplauso en la poesía latina } \\
\text { y española". }\end{array}$ & 10. & $\begin{array}{l}\text { Jesuita desde 31-I-1756. Cuarto voto, el 2-II-1771. } \\
\text { "Dejó manuscritos: } 1 \text {. Dos tomos de la obra del ex } \\
\text { jesuita Lacunza sobre el Reino temporal de } \\
\text { Jesucristo, traducidos en latín. Véase el artículo } \\
\left.\text { Lacunza en el presente Catálogo [n }{ }^{\circ} 338\right] .2 \text {. } \\
\text { Composiciones latinas y poesías latinas y } \\
\text { españolas. 3. Algunos tratados matemáticos" (BJE, } \\
\text { pp. 603-604). Según Luengo era peor latinista que } \\
\text { Juan Luis Maneiro }{ }^{51} \text {, si bien lo hacía por } \\
\text { diversión }{ }^{52} \text {. }\end{array}$ & $\begin{array}{l}\text { *Teocaltiche, } 29 \text { (Hervás, 20)- } \\
\text { X-1736- †Bolonia, 17-III-1791. }\end{array}$ \\
\hline $\begin{array}{l}{[325]} \\
\text { GUEVARA Y } \\
\text { BASOAZÁBAL } \\
\text { (otros, } \\
\text { Basoazábal } \\
\text { Ladrón de } \\
\text { Guevara), } \\
\text { Andrés de (2). } \\
\text { MEX. }\end{array}$ & $\begin{array}{l}\text { Filósofo moderno y eclético. Residió } \\
\text { en Bolonia, Roma y Plasencia (Italia), } \\
\text { donde acompañaba al protorrestaurador } \\
\text { de la Compañía, José Pignatelli. En } \\
1767 \text { estudiaba en Tepotzotlán letras } \\
\text { humanas. Residente en Bolonia en } \\
\text { 1773. Puesto que su obra Prodromus } \\
\text { ad Institutiones philosophiae y sus } \\
\text { adaptaciones para uso de estudiantes } \\
\text { fue libro de texto durante el primer } \\
\text { tercio del siglo XIX, se conservan } \\
\text { numerosos ejemplares. }\end{array}$ & 10. & $\begin{array}{l}\text { Jesuita desde } 18 \text {-V-1764. Estudió filosofía, teología } \\
\text { y matemáticas. "Imprimió: 1. Prodromus ad } \\
\text { Institutiones philosophiae, sive elementa matheseos } \\
\text { institutionibus philosophicis, certe physicis } \\
\text { praemittenda, opus ad usum mexicanae juventutis } \\
\text { legali Guatimalensium academiae dicatum ab } \\
\text { Andraea de Guevara et Basoazabal Guanaxuatensi } \\
\text { presbyter. Romae, 1796. 2. Institutionum } \\
\text { elementarium Philosophiae ad usum Maexicanae } \\
\text { juventutis. Romae, 1796-1798, volúms. 4" (BJE, p. } \\
605 \text { ). Obra dentro de la línea filosófica del P. } \\
\text { Francisco Jacquier (1711- 1788). La obra, moderna } \\
\text { e ilustrada, de Basoazábal, ecléctico convencido, } \\
\text { tuvo gran aceptación durante la primera mitad del } \\
\text { siglo XIX. Da cabida a autores luteranos, } \\
\text { jansenistas, calvinistas, anglicanos, junto a jesuitas } \\
\text { como Rudjer, Lorenzo Hervás o Francisco Javier } \\
\text { Clavigero. No es, pues, extraño que Hervás le } \\
\text { siguiese su producción literaria, con cierta } \\
\text { precisión. }\end{array}$ & $\begin{array}{l}\text { *Guanajuato, 30-XI-1748- } \\
\text { †Plasencia (Italia), 25-III-1801. }\end{array}$ \\
\hline $\begin{array}{l}{[334] \text { ITA }} \\
\text { (HITA) } \\
\text { SANTANA, }\end{array}$ & $\begin{array}{l}\text { Misionero y cronista de viajes. } \\
\text { Misionero en Sinaloa (Batacosa) en } \\
\text { 1767. Permaneció varios años rehén de }\end{array}$ & 15. & $\begin{array}{l}\text { Jesuita desde } 20 \text {-VIII-1746. Cuarto voto, el 2-II- } \\
1765 \text {. Según Hervás, "estando en su prisión, } \\
\text { escribió el año } 1771 \text { una relación y largo diario del }\end{array}$ & $\begin{array}{l}\text { *Puebla de los Ángeles, 6-IX- } \\
\text { 1731-†Córdoba, España, 10-II- }\end{array}$ \\
\hline
\end{tabular}

\footnotetext{
${ }^{51}$ Luengo, Diario, día 19.5.1793.

${ }^{52}$ Sebastián, 1767-1796, vol. II: 187-190.
} 


\begin{tabular}{|c|c|c|c|c|}
\hline $\begin{array}{l}\text { Francisco (2). } \\
\text { MEX. } \\
\text { Fuente para } \\
\text { Maneiro. }\end{array}$ & $\begin{array}{l}\text { Carlos III en el Puerto de Santa María. } \\
\text { Después fue trasladado a Córdoba, } \\
\text { donde murió. Informó a } \\
\text { Sternkianowski (Diario sobre el } \\
\text { destierro de Sonora })^{53} \text {. }\end{array}$ & & $\begin{array}{l}\text { viaje y de los trabajos de los jesuitas misioneros de } \\
\text { Cinaloa, notando particulares virtudes de los que, } \\
\text { entre éstos, habían muerto. De esta relación curiosa } \\
\text { y exacta se han aprovechado algunos escritores de } \\
\text { cosas americanas y, principalmente, el señor } \\
\text { Maneiro, cuyo artículo [n }{ }^{\circ} 133 \text { ] se pone en el } \\
\text { antecedente catálogo de autores de obras impresas" } \\
(B J E, \text { p. 612). }\end{array}$ & 1782. \\
\hline $\begin{array}{l}{[109]} \\
\text { ITURRIAGA } \\
\text { TORIJA, } \\
\text { Manuel } \\
\text { Mariano de } \\
\text { (1). MEX. }\end{array}$ & $\begin{array}{l}\text { Canonista, teólogo y polemista } \\
\text { conservador (íntimo amigo del diarista } \\
\text { Manuel Luengo). Residió en Fano. "El } \\
\text { señor Iturriaga, con el título alegórico: } \\
\text { El dolor rei, escribió en el } 1759 \\
\text { poesías latinas y españolas, con } \\
\text { ocasión de las exequias que la ciudad } \\
\text { de Guatemala hizo a la reina española } \\
\text { María Bárbara, las cuales poesías, } \\
\text { como también la oración fúnebre que } \\
\text { en las dichas exequias dijo el señor } \\
\text { Iturriaga, se imprimieron en Guatemala } \\
\text { por el impresor Joaquín Arévalo, } \\
\text { 1760". Maestro de Teología en el San } \\
\text { Ildefonso de Puebla en 1767. "En su } \\
\text { navegación, desde España hasta Italia, } \\
\text { convirtió un ilustre y noble joven } \\
\text { sueco, llamado Lorenzo Thiulen [1746- } \\
\text { 1833], al cual, porque sus padres } \\
\text { abandonaron totalmente luego que } \\
\text { supieron su conversión, asistió y } \\
\text { socorrió haciéndole igualmente } \\
\text { participante de lo poco que tenía para } \\
\text { su subsistencia" (BJE, p. 302). } \\
\text { Residente en Bolonia en 1773. A partir } \\
\text { de } 1788 \text { se publicó la edición de sus } \\
\text { obras completas: "Algunas de estas } \\
\text { obras se han reimpreso en Italia, como }\end{array}$ & $\begin{array}{l}\text { Muy } \\
\text { importante. } \\
\text { Pensión } \\
\text { doble. }\end{array}$ & $\begin{array}{l}\text { Detalle de la fecha de redacción del artículo: "según } \\
\text { noticia que recibo hoy, } 13 \text { de nov. de } 1793 \text { ". } \\
\text { Teólogo del obispo de Fano. Jesuita desde el } \\
\text { 7-III-1744. Sacerdote de cuarto voto (Puebla de los } \\
\text { Ángeles, 15-VIII-1763). Maestro de Gramática en } \\
\text { Valladolid y de Filosofia en Guatemala; prefecto de } \\
\text { doctrinas en Puebla. Hervás le reseña } 12 \text { impresos, } \\
\text { el primero en la imprenta Biasini de Cesena y el } \\
\text { resto disperso en diversas ciudades italianas (Asís y } \\
\text { Venecia, sobre todo), huyendo de la censura de los } \\
\text { inquisidores dominicos". Imprimió: } 1 . \text { Dominicus } \\
\text { Lanzerinus, [...] super attritione venialium ex metu } \\
\text { purgatorii concepta. Cesenae, 1778. Typis Gregorii } \\
\text { Biasinii. 2. Esame critico teologico che servira per } \\
\text { fare un "errata corrige" ad un certo libro stampato } \\
\text { in Bologna da un certo Lelio della Volpe l'anno } \\
\text { 1778, intitulato "Raccolta di varii esercizii di } \\
\text { pietà..." vi si spiega tutto quello, che e necessario di } \\
\text { sapere ed operare per vivere da vero cristiano, etc. } \\
\text { In Venezia, 1779. } 3 \text {. Dissertazione teologico- } \\
\text { morale intorno alla santificazione delle feste. } \\
\text { Modena, 1780. 4. Dissertazione intorno al dolore } \\
\text { necesario per il valore, e per il frutto del } \\
\text { Sagramento della Penitenza. Assisi, 1780. } 5 . \\
\text { Saggio di risposta all'autore degl'Annali detti } \\
\text { "Ecclesiastici" in difesa della "Dissertazione } \\
\text { intorno al dolore necessario per il valore, e per il } \\
\text { frutto del sagramento della Penitenza", Assisi, }\end{array}$ & $\begin{array}{l}\text { *Puebla de los Ángeles } \\
\text { (México), 24-XII-1728- †Fano, } \\
\text { 31-VIII-1819. }\end{array}$ \\
\hline
\end{tabular}

\footnotetext{
${ }^{53}$ Ibíd., 1767-1796, vol. I: 413-415.
}

83 Antonio Astorgano Abajo y Fuensanta Garrido Domené. Panorama esquemático ... 60-120. 


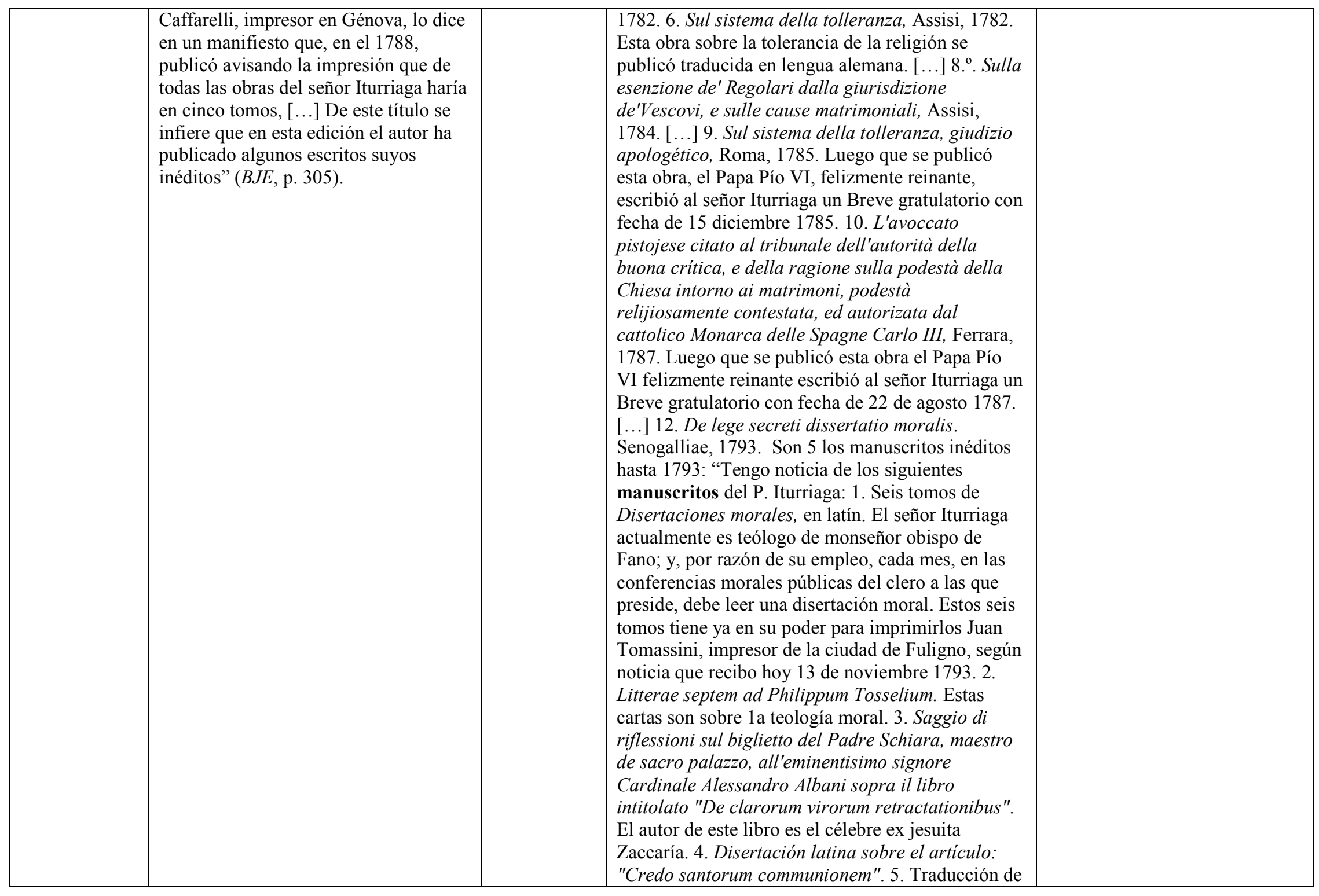

84 Antonio Astorgano Abajo y Fuensanta Garrido Domené. Panorama esquemático ... 60-120. 


\begin{tabular}{|c|c|c|c|c|}
\hline & & & $\begin{array}{l}\text { algunos dramas de Metastasio y de algunas } \\
\text { comedias morales francesas en verso español" } \\
(B J E, \text { pp. 301-306). }\end{array}$ & \\
\hline $\begin{array}{l}{[110]} \\
\text { IZQUIERDO } \\
\text { GUTIÉRREZ, } \\
\text { Josef Joaquín } \\
\text { (1). MEX. }\end{array}$ & $\begin{array}{l}\text { Poeta y traductor. En } 1767 \text { estaba en el } \\
\text { colegio de Valladolid de Mechoacán } \\
\text { (prefecto de catequismo). Residió en } \\
\text { Bolonia, donde falleció (está enterrado } \\
\text { en la parroquia de San Próculo, XIII, } \\
\text { a. d. })^{54} \text {. }\end{array}$ & 10 . & $\begin{array}{l}\text { Jesuita desde 21-VIII-1747. Cuarto voto, el 15- } \\
\text { VIII-1766. Traductor de Metastasio. "Imprimió en } \\
\text { Méjico: Oración sagrada pronunciada en la } \\
\text { dedicación de la iglesia del colegio jesuitico de } \\
\text { Guanajato. Manuscritos: } 1 \text {. Un tomo de obras } \\
\text { poéticas. } 2 \text {. Traducción de parte de las obras } \\
\text { poéticas de Metastasio en lengua española" (BJE, p. } \\
\text { 306). }\end{array}$ & $\begin{array}{l}\text { * Zacatecas, 25-III-1731- } \\
\text { †Bolonia, 22-XI-1785. }\end{array}$ \\
\hline $\begin{array}{l}{[117]} \\
\text { LANDÍVAR } \\
\text { RUIZ DE } \\
\text { BUSTAMANTE, } \\
\text { Rafael de (1). } \\
\text { MEX. }\end{array}$ & $\begin{array}{l}\text { Poeta. Residió en Bolonia. En } 1767 \text { era } \\
\text { rector y catedrático de Moral del } \\
\text { Seminario de Guatemala. En Bolonia } \\
\text { fue superior de una de las casas de } \\
\text { jesuitas. Residente en Bolonia en } 1773 \text {. } \\
\text { Tras la extinción vivió en Fano y } \\
\text { Bolonia. Redactó el prólogo a la Vida } \\
\text { de la Madre de Dios de José Ignacio } \\
\text { Vallejo (Cesena, 1779). F. Sebastián } \\
\text { subraya sus dotes como pedagogo, por } \\
\text { encima de las poéticas: "siempre se } \\
\text { mostraba alegre y placentero con todos, } \\
\text { siendo muy meloso en sus palabras, } \\
\text { muy apacible en su trato y muy } \\
\text { divertido en su conversación [...]. Pasó } \\
\text { muchos años en el penoso trabajo de } \\
\text { enseñar [...]. De aquí provenía aquel su } \\
\text { continuado estudio, para no proponer } \\
\text { ni enseñar sino aquello que más } \\
\text { conveniente juzgaba para el } \\
\text { aprovechamiento de sus discípulos",55. }\end{array}$ & 15. & $\begin{array}{l}\text { Jesuita desde } 17-\text {-II-1750. Cuarto voto, el 2-II-1765. } \\
\text { De débil complexión, fue maestro de Gramática en } \\
\text { Puebla y de Retórica en la ciudad de México; de } \\
\text { Retórica y Filosofía y rector en Guatemala. Hervás } \\
\text { le reseña las dos primeras ediciones de su virgiliano } \\
\text { poema Raphaelis Landivar rusticatio mexicana, } \\
\text { seu rariora quaedam ex agris mexicanis decerpta, } \\
\text { atque in libros decem distributa. La primera de } \\
\text { Módena (1781) y la segunda corregida y aumentada } \\
\text { (Bolonia, 1782). También la "Oración fúnebre } \\
\text { latina en las honras funerales que el cabildo de la } \\
\text { catedral de Guatemala hizo al señor don Francisco } \\
\text { Josef de Figueredo y Victoria, segundo Arzobispo } \\
\text { de dicha catedral; impresa en la imprenta del } \\
\left.\text { colegio de San Ignacio de Puebla (1765. } 4^{\circ}\right) \text {. Tiene } \\
\text { algunas obras manuscritas en idioma español y } \\
\text { algunas poesías latinas" (BJE, p. } 323)^{56} . \text { F. } \\
\text { Sebastián dice que "por divertir algún tanto el } \\
\text { ánimo, escribió en verso latino, [...] Rusticatio } \\
\text { Mexicana, por evagar el ánimo"s7. }\end{array}$ & $\begin{array}{l}\text { Guatemala, 27-X-1731- } \\
\text { †Bolonia, 27-IX-1793 (Santa } \\
\text { María de las Muratelle, C, 347). }\end{array}$ \\
\hline
\end{tabular}

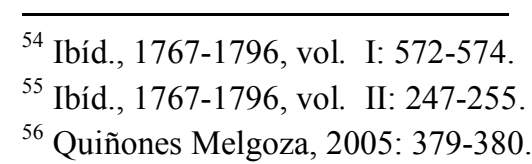

85 Antonio Astorgano Abajo y Fuensanta Garrido Domené. Panorama esquemático ... 60-120. 


\begin{tabular}{|c|c|c|c|c|}
\hline $\begin{array}{l}{[122]} \\
\text { LAZCANO, } \\
\text { Francisco } \\
\text { Javier (1). } \\
\text { MEX. No fue } \\
\text { expulso. }\end{array}$ & $\begin{array}{l}\text { Teólogo. Doctor en teología, el padre } \\
\text { Lazcano fue un publicista, autor de } \\
\text { innumerables folletos, discursos y } \\
\text { biografías. }\end{array}$ & 10. & $\begin{array}{l}\text { Jesuita desde 22-X-1717. "Fue catedrático, teólogo } \\
\text { eminente, de la universidad de Méjico, en donde, el } \\
\text { 1762, murió con opinión de santidad; por lo que, } \\
\text { justamente, escribió y publicó su vida, en Méjico, el } \\
\left.\text { jesuita Josef Vallarta [n }{ }^{\circ} 248\right] \text {. Imprimió: 1. Índice } \\
\text { práctico moral para los sacerdotes que auxilian } \\
\text { moribundos (1750). 2. Opusculum } \\
\text { theophilosophicum de Principatu, seu antelatione } \\
\text { Marianae gratiae. (Venecia, 1755. Esta edición es } \\
\text { segunda, la primera se hizo el } 1750 \text { en Méjico). } 3 . \\
\text { Vida del doctor Juan Antonio Oviedo [1670-1757], } \\
\text { de la Compañía de Jesús, impresa en Méjico" (BJE, } \\
\text { p. 337). }\end{array}$ & $\begin{array}{l}\text { *Puebla de los Ángeles, } 24-X- \\
1702-\dagger \text { México, 1762. Fama de } \\
\text { santo. }\end{array}$ \\
\hline $\begin{array}{l}\text { [344] LÓPEZ, } \\
\text { Vicente (2). } \\
\text { MEX. } \\
\text { Biografía con } \\
\text { pocos datos. } \\
\text { No fue } \\
\text { expulso. }\end{array}$ & $\begin{array}{l}\text { Humanista. Sommervogel, siguiendo a } \\
\text { Beristáin, dice que nació en Lucena el } \\
15 \text { de noviembre de } 1691 \text {. Enseñó } \\
\text { retórica, filosofía y teología en } \\
\text { diferentes colegios. Fue calificador del } \\
\text { Santo Oficio. Según Hervás, "Murió en } \\
\text { México hacia el año 1758" (BJE, p. } \\
621 \text { ). }\end{array}$ & 10. & $\begin{array}{l}\text { Fue admitido en Tepozotlán el } 2 \text { de febrero de } \\
1709 . \text { Cuarto voto. "Nació en Córdoba y se ignora } \\
\text { si entró en la Compañía de Jesús en Sevilla o en } \\
\text { Méjico, para donde salió el año } 1715 \text {. Estudió y } \\
\text { enseñó con aplauso las bellas letras, la filosofía y } \\
\text { teología, y profesó solemnemente. Escribió } \\
\text { algunos tratados de varia erudición y algunos } \\
\text { himnos a Nuestra Señora de Guadalupe de Méjico, } \\
\text { que se imprimieron anónimamente. Al principio de } \\
\text { la obra Bibliotheca americana auctore D. Joanne } \\
\text { de Eguiarra et Eguren [1696-1763] (México, } \\
\text { 1755), se lee: "De bibliotheca doct. Joannis } \\
\text { Eguiarae et mexicanorum ingenio dialogus authore } \\
\text { Vicentio López corduvensi". Este diálogo contiene } \\
24 \text { páginas en folio. Al fin del diálogo el autor, } \\
\text { escribiendo en el 1755, dice que había ya casi } 40 \\
\text { años que estaba en América" (BJE, pp. 621-622). }\end{array}$ & $\begin{array}{l}\text { *Lucena (Córdoba, España), 5- } \\
\text { XI-1691- †México, } 1757 .\end{array}$ \\
\hline $\begin{array}{l}\text { [123] LÓPEZ } \\
\text { ADÁN, Juan } \\
\text { Francisco (1). } \\
\text { MEX. }\end{array}$ & $\begin{array}{l}\text { Superior y teólogo. Su padre era } \\
\text { administrador general de las rentas } \\
\text { reales. Huérfano de madre, se mudó a } \\
\text { Veracruz. Residió en Ferrara. Maestro }\end{array}$ & Importante & $\begin{array}{l}\text { Jesuita desde 12-XI-1715. Sacerdote de cuarto voto } \\
\text { desde 2-II-1733. "Imprimió: } 1 \text {. El 1754, en Roma, } \\
\text { un librito sobre la Santísima Virgen de Guadalupe } \\
\text { con súplica al Papa Benedicto XIV, para lograr la }\end{array}$ & $\begin{array}{l}\text { *Guarenas (Caracas), } \\
\text { 5-IV-1699-†Ferrara, 6-I-1783 } \\
\text { ("Está sepultado en la Iglesia de }\end{array}$ \\
\hline
\end{tabular}

\footnotetext{
${ }^{57}$ Sebastián, 1767-1796, vol. II: 255.
} 


\begin{tabular}{|c|c|c|c|c|}
\hline $\begin{array}{l}\text { Biografiado } \\
\text { por Maneiro, } \\
\text { fuente esencial } \\
\text { de Hervás. }\end{array}$ & $\begin{array}{l}\text { de Teología y rector en México. } \\
\text { Director de la Casa de Ejercicios de } \\
\text { Puebla en } 1767 \text {."López, desterrado a } \\
\text { Italia, por algunos años, se ocupó } \\
\text { mucho en escribir, mas no se ha } \\
\text { publicado noticia de la calidad y } \\
\text { cantidad de sus manuscritos, que serán } \\
\text { estimables" (BJE, p. 340). Su legado } \\
\text { más importante en la historia de la } \\
\text { Orden fue conseguir de su amigo } \\
\text { Benedicto XIV, con ocasión de su viaje } \\
\text { a Roma como procurador a las Cortes, } \\
\text { el patronato de la Virgen de Guadalupe } \\
\text { sobre la nación mexicana el } 14-I V- \\
\text { 1754. Félix de Sebastián se complace } \\
\text { en relatar sus éxitos en Roma }{ }^{58} \text {. }\end{array}$ & & $\begin{array}{l}\text { gracia de su oficio [Officium B. Mariae Virginis de } \\
\text { Guadalupe]. Este libro se reimprimió en Ferrara, } \\
\text { 1784. 2. En Barcelona imprimió el devocionario } \\
\text { Oraciones devotas a San Ignacio para todo el mes } \\
\text { de agosto, traducidas de la lengua italiana. } 3 \text {. } \\
\text { Imprimió en Puebla de los Ángeles un tomo en } \\
\text { cuarto sobre los ritos sagrados [Manual de } \\
\text { Párrocos ajustado al Ritual Romano]. } 4 \text {. Los } \\
\text { preciosos volúmenes de Theologia dogmatica } \\
\text { tribus tomis, Roma, 1757, que López había escrito } \\
\text { y se conservaban aún inéditos el 1755, fueron } \\
\text { elogiados por el general de los jesuitas [Ignacio } \\
\text { Visconti] al provincial jesuita de Méjico, } \\
\text { encomiando la sabiduría y el mérito de López, entre } \\
\text { los jesuitas, lo cual era fenómeno rarísimo, por lo } \\
\text { que ella descubre bien el gran mérito de López por } \\
\text { su virtud y ciencia. [...] Es común opinión en esta } \\
\text { ciudad de Roma que, por orden pontificio, se haya } \\
\text { impreso la mayor parte de las disertaciones } \\
\text { teológico dogmáticas de López, en } 4 \text { tomos en } \\
\text { folio" (BJE, p. 339). }\end{array}$ & Santa Romana" (BJE, p. 338). \\
\hline $\begin{array}{l}{[126] \text { LOZANO }} \\
\text { RUIZ, } \\
\text { Francisco } \\
\text { Javier (1). } \\
\text { TOLEDO y } \\
\text { MEX. }\end{array}$ & $\begin{array}{l}\text { Poeta. Residió en Imola. Prefecto de } \\
\text { congregación en Zacatecas y en la } \\
\text { Residencia de Parras (confesor), donde } \\
\text { se hallaba en 1767. Residente en } \\
\text { Bolonia en 1773. Retornó a España en } \\
1798 .\end{array}$ & $\begin{array}{l}15 . \\
\text { Pensión } \\
\text { doble. }\end{array}$ & $\begin{array}{l}\text { Suscriptor a la enciclopedia de Idea dell'Universo. } \\
\text { Jesuita desde } 14 \text { (Hervás, 15)-IV-1737. Cuarto } \\
\text { voto, el 2-II-1755. Pasó a México en 1744. Maestro } \\
\text { de gramática en Oaxaca y de filosofía en Durango. } \\
\text { "Imprimió: 1. Recuerdos de las eternas verdades } \\
\text { confirmados con la Sagrada Escritura, y expuestos } \\
\text { en décimas castellanas por el presbitero Dn. } \\
\text { Francisco Javier Lozano, natural de Valdepeñas. } \\
\text { Cesena, 1788. En la imprenta de Gregorio Biasini, } \\
2 \text { volúmenes. 2. Atributo de Dios y misterios de } \\
\text { Dios-hombre, que compuso en verso heroico latino } \\
\text { Don Diego Josef Abad, mejicano, y traduce en } \\
\text { décimas castellanas Don Francisco Javier Lozano. } \\
\text { Barcelona, 1788. Manuscritos: Tiene dispuestas } \\
\text { para la prensa las siguientes obras en décimas }\end{array}$ & $\begin{array}{l}\text { *Valdepeñas, 9-IX (Hervás, 30- } \\
\text { VIII) 1721-†Elche (Alicante), } \\
\text { 11-VI-1801. }\end{array}$ \\
\hline
\end{tabular}

\footnotetext{
${ }^{58}$ Ibíd., 1767-1796, vol. I: 428-436.
} 


\begin{tabular}{|c|c|c|c|c|}
\hline & & & $\begin{array}{l}\text { españolas: 1. Séneca cristiano o consuelos en todas } \\
\text { las adversidades. } 2 \text {. El Petrarca filosófico o } \\
\text { desconsuelos en las felicidades de esta vida" (BJE, } \\
\text { p. 343). }\end{array}$ & \\
\hline $\begin{array}{l}{[133]} \\
\text { MANEIRO } \\
\text { MONSABAL, } \\
\text { Juan Luis (1). } \\
\text { MEX. Fuente } \\
\text { fundamental } \\
\text { para conocer } \\
\text { la parte } \\
\text { mexicana de la } \\
\text { BJE. }\end{array}$ & $\begin{array}{l}\text { Biógrafo y latinista. Residió en } \\
\text { Bolonia. En } 1767 \text { estudiaba Teología } \\
\text { en el Colegio Máximo de San Pedro y } \\
\text { San Pablo. Residente en Bolonia en } \\
\text { 1773. Regresó a México en } 1799 . \\
\text { Enterrado en la Iglesia de los } \\
\text { Carmelitas Descalzos. }\end{array}$ & 20. & 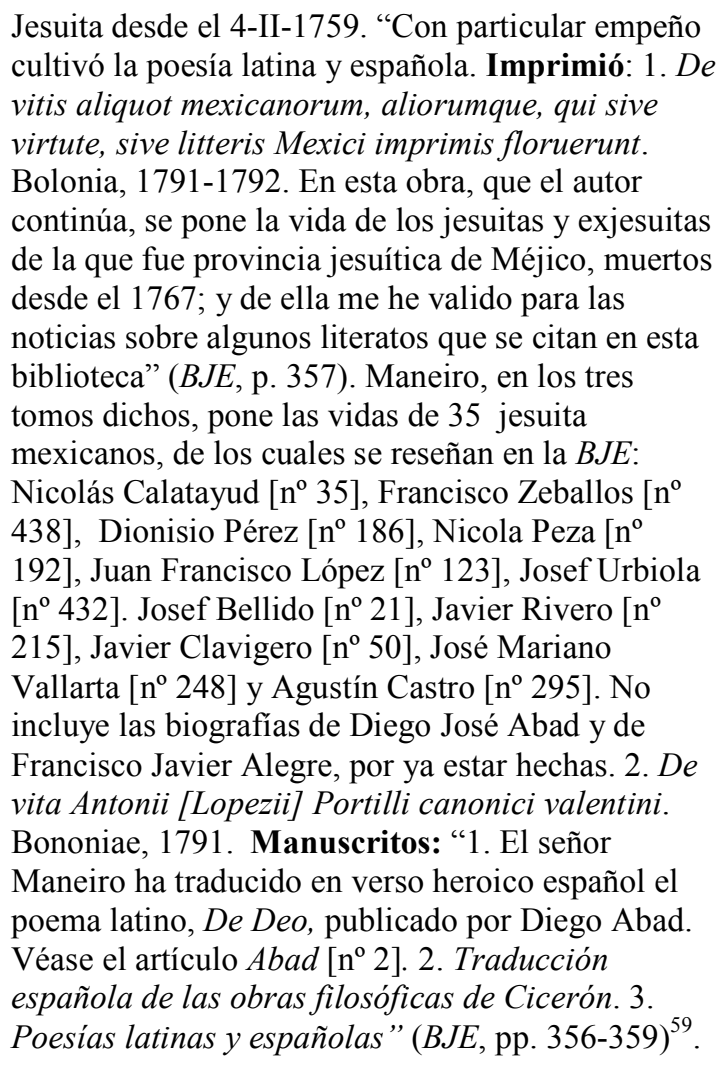 & $\begin{array}{l}\text { *Veracruz (Puebla de los } \\
\text { Ángeles, según Hervás), 2-II- } \\
\text { 1744-†Ciudad de México, } \\
\text { 16-XI-1802. }\end{array}$ \\
\hline $\begin{array}{l}{[351]} \\
\text { MÁRQUEZ } \\
\text { OCHOA, Pedro }\end{array}$ & $\begin{array}{l}\text { Arquitectólogo, erudito y polígrafo. } \\
\text { Reside en Roma desde antes de febrero } \\
\text { de } 1780 \text { y coincidirá con Hervás en } I l\end{array}$ & $\begin{array}{l}5 . \\
\text { Pensión }\end{array}$ & $\begin{array}{l}\text { Jesuita desde 4-III-1761. Con la tardía publicación } \\
\text { de Delle case di Città degli antichi romani ( } 1795 \text {, } \\
\text { cuando hacía un año que se había cerrado la BJE), }\end{array}$ & $\begin{array}{l}\text { *Rincón de León (Mechoacán), } \\
\text { 22-II-1741- †Ciudad de México, } \\
\text { 2-IX-1820. }\end{array}$ \\
\hline
\end{tabular}

$\overline{{ }^{59} \text { Quiñones Melgoza, 2005: 380-381. }}$

88 Antonio Astorgano Abajo y Fuensanta Garrido Domené. Panorama esquemático ... 60-120. 


\begin{tabular}{|c|c|c|c|c|}
\hline $\begin{array}{l}\text { José (2). } \\
\text { MEX. Regresó } \\
\text { a Valencia } \\
(1798-1801) \text { y } \\
\text { volvió a } \\
\text { México el 12- } \\
\text { X-1816. }\end{array}$ & $\begin{array}{l}\text { Gesú. Restaurador de la Compañía. } \\
\text { Estudiaba Teología en el Colegio } \\
\text { Máximo San Pedro y San Pablo en } \\
\text { 1767. En } 1773 \text { residía en Bolonia, pero } \\
\text { pronto se trasladó a Roma. Tenía una } \\
\text { actitud cosmopolita, fruto de su } \\
\text { apertura y amplia erudición. Fue } \\
\text { protegido del influyente embajador } \\
\text { español ante la Santa Sede, Nicolás de } \\
\text { Azara, quien le facilitó participar en las } \\
\text { excavaciones que el diplomático dirigía } \\
\text { en Tívoli. Asimiló la corriente } \\
\text { internacional neoclásica, que le llevó a } \\
\text { estudiar la antigüedad romana que, a su } \\
\text { vez, despertó su interés en la } \\
\text { arqueología mexicana. }\end{array}$ & triple. & $\begin{array}{l}\text { inició Márquez su carrera de polígrafo, con } \\
\text { marcada preferencia por la arqueología y la } \\
\text { arquitectura romana antigua. Quedan sin publicar } \\
\text { varios opúsculos dedicados a la geometría, y } \\
\text { especialmente el que se puede considerar su libro } \\
\text { más importante, los "Apuntamientos } \\
\text { arquitectónicos por orden alfabético según las } \\
\text { doctrinas de Marco Vitrubio Polión". "Escribió: } 1 . \\
\text { Descripción del circo de Caracalla, publicado en } \\
\text { italiano por Carlos Fea y traducido al español. } 2 \text {. } \\
\text { Introducción a la arquitectura civil. 3. Le case de' } \\
\text { nobili romani in città secondo Vitruvio. Esta obra } \\
\text { se imprime en Roma [salió en 1795]" (BJE, pp. } \\
\text { 627-629). No se recogen importantes obras } \\
\text { posteriores, como Sobre lo bello en general (1801) } \\
\text { e Illustrazioni della Villa di Mecenate a Tivoli } \\
\text { (1812). Para Márquez, las placas y textos hallados } \\
\text { en sus exploraciones arqueológicas probaban la } \\
\text { habilidad de los indios en astronomía, escultura y } \\
\text { arquitectura, es decir, que los habitantes naturales } \\
\text { de América eran una nación civilizada antes de la } \\
\text { llegada de los europeos. Al igual que Clavigero, } \\
\text { Márquez justificaba, en cierto modo, los sacrificios } \\
\text { humanos aztecas, alegando que los romanos } \\
\text { practicaban ritos de crueldad semejante. }\end{array}$ & \\
\hline $\begin{array}{l}\text { [359] MINER } \\
\text { LEGARRA, } \\
\text { Blas José } \\
\text { Manuel (2). } \\
\text { CAS y MEX. } \\
\text { Escribió } \\
\text { mucho, pero } \\
\text { se ha perdido } \\
\text { toda su obra, } \\
\text { elogiada por }\end{array}$ & $\begin{array}{l}\text { Historiador, naturalista y lingüista. En } \\
1767 \text { era misionero en Chinipas. } \\
\text { Residió en Roma: "En Italia, el señor } \\
\text { Miner vivió con sumo retiro, ocupado } \\
\text { en sus ejercicios privados de } \\
\text { eclesiástico y en la literatura. En el } \\
1780 \text { se dedicó a asistir en el hospital } \\
\text { lateranense en Roma y en el siguiente, } \\
\text { por junio, murió de enfermedad } \\
\text { contraída con la asistencia a los }\end{array}$ & 30. & $\begin{array}{l}\text { Jesuita desde 20-VI-1755. Secularizado en Ferrara, } \\
\text { antes de la extinción (1773). "El señor Miner, que } \\
\text { pasaba gran parte del día en las bibliotecas } \\
\text { públicas, y en escribir empleaba lo demás del } \\
\text { tiempo útil para el estudio, dejó muchos volúmenes } \\
\text { manuscritos. Visitando yo, casualmente, al } \\
\text { doctísimo y célebre exjesuita Pedro Lazzeri [1710- } \\
\text { 1789], bibliotecario del eminentísimo señor } \\
\text { cardenal Zelada, encontré sobre su bufete más de } \\
\text { seis volúmenes manuscritos, que a la dicha }\end{array}$ & $\begin{array}{l}\text { *Tolosa (Guipúzcoa), 3-II- } \\
\text { 1734- †Roma, 28-V-1788. (Hijo } \\
\text { de Juan Nicolás y Josefa. } \\
\text { Partida de Bautismo en } \\
\text { Parroquia de Santa María de } \\
\text { Tolosa, VIII, f. 100v.). }\end{array}$ \\
\hline
\end{tabular}




\begin{tabular}{|c|c|c|c|c|}
\hline $\begin{array}{l}\text { Faustino } \\
\text { Arévalo }^{60} \text {. }\end{array}$ & enfermos" (BJE, p. 635). & & 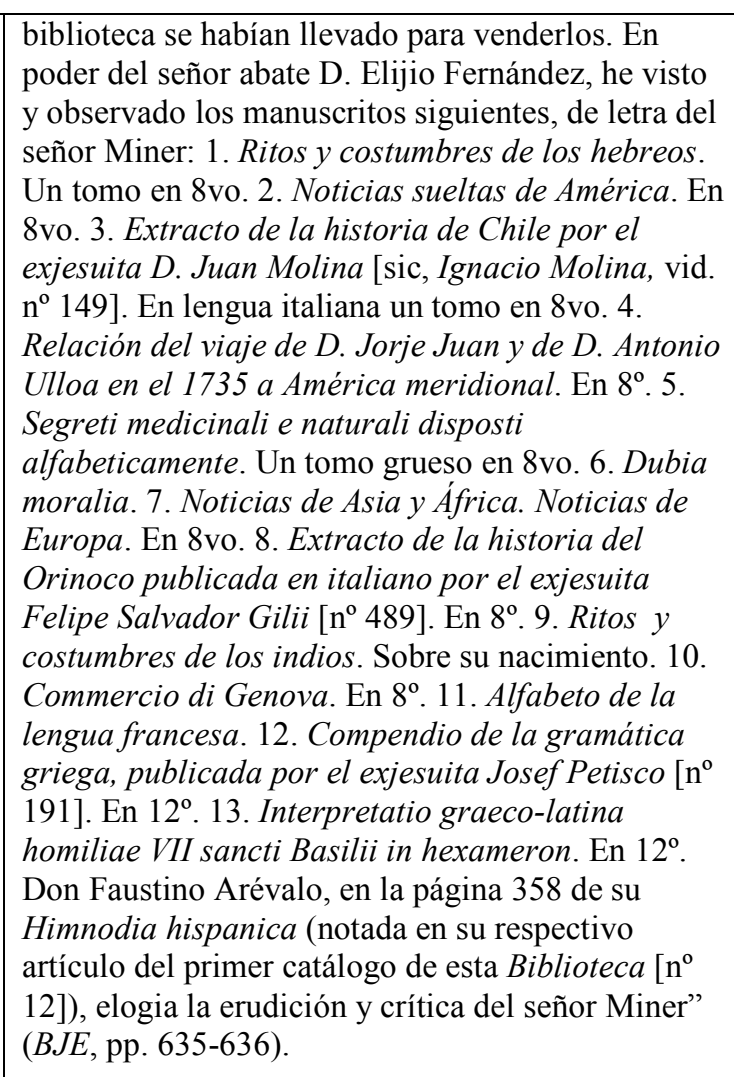 & \\
\hline $\begin{array}{l}{[366] \text { [RUIZ }} \\
\text { DE LA] MOTA } \\
\text { ZuGAZA, Juan } \\
\text { Ignacio (2). } \\
\text { MEX. }\end{array}$ & $\begin{array}{l}\text { Poeta latino. Residió en Roma desde } \\
\text { antes de } 1774 \text {. Rector y maestro de } \\
\text { Teología en Pátzcuaro, Puebla y } \\
\text { México. En } 1767 \text { era rector y prefecto } \\
\text { de estudios mayores del Colegio de } \\
\text { Guadalajara. }\end{array}$ & 5. & $\begin{array}{l}\text { Jesuita desde el } 18-\mathrm{IV}-1740 \text {. Cuarto voto, } 15-\mathrm{VIII} \\
\text { 1757. Secularizado el } 27-\mathrm{V}-1769 \text { en el Puerto de } \\
\text { Santa María. "Escribió: Poema latino sobre la } \\
\text { Jararagua, país en el obispado de Valladolid, de } \\
\text { Nueva España" (BJE, p. } 639 \text { ). }\end{array}$ & $\begin{array}{l}\text { *Ciudad de México, } \\
\text { 24-VI-1724-†Roma, 10-X-1797. }\end{array}$ \\
\hline [165] NOROÑA & Misionero. Reside en Roma. Misionero & 10. & Jesuita desde $20-\mathrm{XI}-1753$. Cuarto voto, el $15-\mathrm{VIII}-$ & *Antequera, Oaxaca, \\
\hline
\end{tabular}

$\overline{{ }^{60} \text { Astorgano Abajo, 2009g: 388-390. }}$.

90 Antonio Astorgano Abajo y Fuensanta Garrido Domené. Panorama esquemático ... 60-120. 


\begin{tabular}{|c|c|c|c|c|}
\hline $\begin{array}{l}\text { CHIRINO, } \\
\text { Nicolás (1). } \\
\text { MEX. }\end{array}$ & $\begin{array}{l}\text { circular en Guanajuato en } 1767 . \\
\text { Residente en Bolonia en } 1773 \text {. "Está } \\
\text { sepultado en la iglesia de S. Salvador } \\
\text { in unda de Roma" (BJE, p. } 411 \text { ). Félix } \\
\text { de Sebastián pone una breve reseña } \\
\text { biográfica, pero sin aludir para nada a } \\
\text { sus escritos }{ }^{61} \text {. }\end{array}$ & & $\begin{array}{l}\text { 1769. Protegido de Manuel Rojo, arzobispo de } \\
\text { Manila. Amigo de Clavigero, pues en su única } \\
\text { obra publicada, Rasgo breve de la grandeza } \\
\text { guanajuateña en la dedicación de la iglesia de la } \\
\text { Compañia de Jesús en la ciudad de Guanajuato } \\
\text { (1767), "hay poesías españolas del erudito D. } \\
\text { Francisco Javier Clavigero" (BJE, p. 411). }\end{array}$ & 1-IV-1732-†Roma, 4-IX- 1791. \\
\hline $\begin{array}{l}{[169] \text { ORRIO, }} \\
\text { Francisco } \\
\text { Javier Alejo } \\
\text { de (1). CAS y } \\
\text { MEX. No fue } \\
\text { expulso. }\end{array}$ & $\begin{array}{l}\text { Naturalista y poeta. "En julio de } 1764 \\
\text { murió en Veracruz, al embarcarse para } \\
\text { visitar las misiones y los colegios } \\
\text { ultramarinos de la provincia jesuítica } \\
\text { de Méjico". Fue un gran propagandista } \\
\text { del culto a la Virgen de Guadalupe en } \\
\text { Zacatecas: 1. Descripción en prosa y } \\
\text { verso de las fiestas con que la Ciudad } \\
\text { de Zacatecas celebró la confirmación } \\
\text { del Patronato de Nuestra Señora de } \\
\text { Guadalupe en toda la América } \\
\text { (México, 1759). } 2 \text {. Sermón } \\
\text { panegyrico predicado en la iglesia } \\
\text { parroquial de Zacatecas con la } \\
\text { ocasión de haberse dedicado un nuevo } \\
\text { altar, y colocado en él a la Señora de } \\
\text { Guadalupe, a quien habia jurado por } \\
\text { su Patrona Universal dicha Ciudad, } \\
\text { por el mes de septiembre de } 1758 \\
\text { (México, 1762). }\end{array}$ & 10. & $\begin{array}{l}\text { Jesuita desde 18-VII-1735. Cuarto voto. Fue rector } \\
\text { del colegio de Zacatecas. Según Hervás: } \\
\text { "Imprimió en Méjico una obra contra los adamitas } \\
\text { sobre la población de América. } 4 \text {. }^{\circ} \text { [Solución del } \\
\text { gran Problema acerca de la población de las } \\
\text { Américas en que, sobre el fundamento de los Libros } \\
\text { Santos, se descubre fácil camino a la } \\
\text { transmigración de los hombres del uno al otro } \\
\text { Continente; y cómo pudieron pasar al Nuevo } \\
\text { Mundo, no solamente las bestias de servicio, sino } \\
\text { también las fieras nocivas. Y con esta ocasión se } \\
\text { satisface plenamente al delirio de los Pre- } \\
\text { Adamitas, apoyado con esta dificil objeción hasta } \\
\text { ahora no bien desatada, México, 1763]. } \\
\text { Manuscritos: Mineralojía. Obra en verso español, } \\
\text { la cual el autor después aumentó y puso en verso } \\
\text { latino. Esta obra, que constaba de dos tomos, estaba } \\
\text { en poder de D. Manuel Lasaga, empleado en las } \\
\text { minas de Nueva España" (BJE, pp. } 415-416 \text { ). No } \\
\text { aparecen los dos tomos manuscritos del curso } \\
\text { filosófico, Novum Philosophiae Semen scientias } \\
\text { omnes virtute completens. Zacatecas, 1750. }\end{array}$ & $\begin{array}{l}\text { *Reino de Navarra, 23-IV- } \\
1717-\dagger \text { Veracruz, VII-1764. }\end{array}$ \\
\hline $\begin{array}{l}\text { [170] ORTEGA } \\
\text { MOTA, Josef } \\
\text { Antonio de } \\
\text { (1). MEX. }\end{array}$ & $\begin{array}{l}\text { Misionero y lingüista. Según las listas, } \\
\text { en } 1767 \text { estaba en el Colegio del } \\
\text { Espíritu Santo de Puebla (capellán), } \\
\text { pero según Hervás, "Se empleó } \\
\text { muchos años en la misión de la }\end{array}$ & 15. & $\begin{array}{l}\text { Jesuita desde 23-IV-1717. Cuarto voto, el 2-II- } \\
\text { 1735. Según Hervás: "Imprimió: 1. Vocabulario y } \\
\text { reglas gramaticales de la lengua Cora (Méjico, } \\
\text { 1732). La lengua Cora se habla en el Nayarit. } 2 . \\
\text { Apostólicos afanes de la Compañia de Jesús, }\end{array}$ & $\begin{array}{l}\text { *Traxcala, 15-IV-1700-†Puerto } \\
\text { de Santa María (Cádiz), 2-VII- } \\
1768 .\end{array}$ \\
\hline
\end{tabular}

\footnotetext{
${ }^{61}$ Sebastián, 1767-1796, vol. II: 197.
}

91 Antonio Astorgano Abajo y Fuensanta Garrido Domené. Panorama esquemático ... 60-120. 


\begin{tabular}{|c|c|c|c|c|}
\hline & $\begin{array}{l}\text { provincia del Nayarit, desde donde, en } \\
\text { la expulsión de los jesuitas españoles, } \\
\text { fue traído en arresto al Puerto de Santa } \\
\text { María, y en esta prisión voló a los } \\
\text { eternos reposos para gozar el premio } \\
\text { eterno de su apostolado en las misiones } \\
\text { del Nayarit" (BJE, p. 416). Según Félix } \\
\text { de Sebastián: "Volvió después a la } \\
\text { Provincia, donde sirvió siempre } \\
\text { utilísimamente en el confesionario y } \\
\text { púlpito", describiendo después la tierra } \\
\text { y conquista del Nayarit }{ }^{62} \text {. }\end{array}$ & & $\begin{array}{l}\text { (Barcelona, 1754)". Hervás lo considera } \\
\text { coordinador de la obra publicada en Barcelona en } \\
1754 \text { Apostólicos afanes de la Compañía de Jesús, } \\
\text { en la que intervinieron varios jesuitas: "La primera } \\
\text { parte de esta obra se escribió por D. Josef Ortega y, } \\
\text { a instancias del exjesuita mejicano D. [Juan] } \\
\text { Francisco López, se compiló por el jesuita } \\
\text { [aragonés] Francisco Fluviá. La segunda parte de } \\
\text { dicha obra se compiló por el jesuita mejicano Juan } \\
\text { Antonio Baltasar según las relaciones del misionero } \\
\text { jesuita Eusebio Francisco Kino" (BJE, pp. 416- } \\
\text { 417). En esta obra también se aprovecharon los } \\
\text { informes de Sedelmayer (n } 493 \text { ). }\end{array}$ & \\
\hline $\begin{array}{l}{[179]} \\
\text { PAREDES, } \\
\text { Ignacio José } \\
\text { de (1). MEX. } \\
\text { No fue } \\
\text { expulso. }\end{array}$ & $\begin{array}{l}\text { Operario y lingüista, especializado en } \\
\text { náhuatl, materia muy interesante para } \\
\text { Hervás: "se aplicó con singular empeño } \\
\text { al estudio de la lengua mejicana } \\
\text { [náhuatl], en que fue eminente y } \\
\text { utilísimo a los indios con celo } \\
\text { apostólico" (BJE, p. 427). Tuvo otros } \\
\text { tres hermanos jesuitas. }\end{array}$ & 25. & $\begin{array}{l}\text { Jesuita desde 20-XII-1720 (otros, 3-XII-1722). } \\
\text { Cuarto voto desde 2-II-1738. "Imprimió: } 1 . \\
\text { Oraciones devotas y hojas volantes de doctrina } \\
\text { cristiana en lengua mejicana para uso de los indios } \\
\text { pobres. } 2 \text {. Catecismo de doctrina cristiana del } \\
\text { jesuita Jerónimo de Ripalda, traducido en lengua } \\
\text { mejicana [México, 1758, dedicatoria al arzobispo } \\
\text { Manuel Rubio Salinas]. 3. Pláticas y sermones en } \\
\text { lengua mejicana para todo el año. } 4 \text {. Compendio } \\
\text { del arte de la lengua mejicana, del jesuita Horacio } \\
\text { Carochi [c.1579-1662], dispuesto con brevedad, } \\
\text { claridad y propiedad por Ignacio de Paredes, } \\
\text { jesuita, morador del colegio destinado solamente } \\
\text { para indios de S. Gregorio de la Compañía de } \\
\text { Jesús en Méjico (Méjico, } 1759 \text { [sic, } 1750 \text { ]. En la } \\
\text { imprenta de la Biblioteca Mejicana. En } 4^{\circ} \text {. Don } \\
\text { Domingo Josef de la Mota en la aprobación de } \\
\text { dicho compendio, dice, que Paredes había impreso } \\
\text { "la del todo necesaria obra del catecismo y la } \\
\text { incomparable del tomo de pláticas y sermones para } \\
\text { todo el año". [...] Después del prologo del dicho } \\
\text { Compendio, el autor pone la siguiente advertencia: } \\
\text { "Estoy disponiendo el tomo castellano de Pláticas y }\end{array}$ & $\begin{array}{l}\text { *Huamantla (Tlaxcala) (Según } \\
\text { Hervás, Gumantla, Puebla de } \\
\text { los Ángeles), 20-II- 1703- } \\
\text { †Ciudad de México, } 1762 \text {. }\end{array}$ \\
\hline
\end{tabular}

\footnotetext{
${ }^{62}$ Ibíd., 1767-1796, vol. I: 81-82.
}

92 Antonio Astorgano Abajo y Fuensanta Garrido Domené. Panorama esquemático ... 60-120. 


\begin{tabular}{|c|c|c|c|c|}
\hline & & & $\begin{array}{l}\text { sermones, que podrá mucho servir universalmente a } \\
\text { todos y, especialmente, a los que tuvieren e1 tomo } \\
\text { mejicano, y se dará a la pública luz. Ignoro si } \\
\text { Paredes llegó a publicar este tomo" (BJE, pp. } 428- \\
429 \text { ). }\end{array}$ & \\
\hline $\begin{array}{l}{[180]} \\
\text { PARREÑO } \\
\text { ESPINOSA, } \\
\text { Josef Julián } \\
\text { (1). MEX. } \\
\text { Biografiado } \\
\text { por Andrés } \\
\text { Cavo [n } 45] \text {, } \\
\text { “su } \\
\text { compañero } \\
\text { inseparable } \\
\text { por 18 años } \\
\text { hasta su } \\
\text { muerte, De } \\
\text { vita Josephi } \\
\text { Juliani } \\
\text { Parreño } \\
\text { (Roma, } \\
\text { 1792)”. }\end{array}$ & $\begin{array}{l}\text { Pedagogo, teólogo y canonista. Rector } \\
\text { del Seminario de San Ildefonso de } \\
\text { México en } 1767 \text {. Secularizado el } \\
27-V-1769 \text { en El Puerto de Santa } \\
\text { María. Residió en Roma, donde } \\
\text { publicó diversas obras de elocuencia, } \\
\text { filosofía y teología. "Habiendo salido } \\
\text { [de Roma] para recobrar su salud } \\
\text { quebrantada, murió en el monasterio } \\
\text { llamado de Galoro de Monjes } \\
\text { Valumbrosanos o de San Juan } \\
\text { Gualberto, que está en las cercanías de } \\
\text { la villa de Ariccia, distante cinco } \\
\text { leguas de Roma. Fue sepultado en la } \\
\text { iglesia de dicho monasterio" (BJE, p. } \\
\text { 429). No es reseñado por Félix de } \\
\text { Sebastián, por haberse secularizado. }\end{array}$ & Importante & $\begin{array}{l}\text { Jesuita desde el 14-VIII-1743. Cuarto voto, el 15- } \\
\text { VIII-1763. Maestro de Retórica y Filosofía en } \\
\text { ciudad de México. En su infancia "aprendió las } \\
\text { habilidades caballerescas que correspondían a la } \\
\text { educación de su nacimiento ilustre, e hizo } \\
\text { particulares progresos en la latinidad y en la } \\
\text { historia". En la biografía hecha por Andrés Cavo, } \\
\text { "en que su autor, testigo ocular de cuanto refiere, da } \\
\text { noticias individuales de las virtudes y de la doctrina } \\
\text { grande de D. Josef Parreño, se hace mención de la } \\
\text { obra que éste escribió en la ciudad de Méjico y se } \\
\text { publicó con el título de Exequias de María Amalia, } \\
\text { reina de España, (1761). En esta obra hay } \\
\text { excelentes poesías de D. Francisco Ganancia [no } \\
\text { 80]". En la citada biografía hecha por Andrés Cavo } \\
\text { se da noticia de las siguientes obras manuscritas } \\
\text { de Parreño, "el cual, luego que llegó a Italia, país de } \\
\text { su destierro, escribió a su familia larga y } \\
\text { elegantísima carta sobre el trato que se debía dar a } \\
\text { los esclavos [negros]. Asimismo escribió en lengua } \\
\text { latina las obras siguientes: } 1 . \text { Preceptos retóricos y } \\
\text { observaciones sobre obras oratorias (Roma, 1778). } \\
2 . \text { Observaciones sobre la obra de Melchor Cano, } \\
\text { intitulada "De locis theologicis". Hizo estas } \\
\text { observaciones en el espacio de } 12 \text { años. } 3 \text {. Tratados } \\
\text { diversos sobre los concilios en general, sobre el } \\
\text { concilio de Constancia, sobre las tradiciones; } \\
\text { sobre el matrimonio y la corrección fraterna y } \\
\text { sobre el cisma general. Manuscrito en fol. } 4 \text {. Del } \\
\text { cuarto y quinto concilios generales. } 5 \text {. De las } \\
\text { versiones de la Sagrada Biblia en lengua vulgar. } 6 \text {. } \\
\text { Notas a la historia del Concilio Tridentino. } 7 . \\
\text { Notas a las Instituciones canónicas de [Claude] }\end{array}$ & $\begin{array}{l}\text { *La Habana, } 8 \text { (11, según } \\
\text { Hervás)-XII-1728- †Ariccia (en } \\
\text { Galloro, Roma, según Zelis), 1- } \\
\text { XI-1785. Epitafio, redactado por } \\
\text { el mismo Parreño, en la } B J E, \text { p. } \\
430 .\end{array}$ \\
\hline
\end{tabular}

93 Antonio Astorgano Abajo y Fuensanta Garrido Domené. Panorama esquemático ... 60-120. 


\begin{tabular}{|c|c|c|c|c|}
\hline & & & $\begin{array}{l}\text { Fleury. 8. Anales desde el principio del año } 1782 \\
\text { hasta octubre del año } 1785 \text { " (BJE, p. } 431) \text {. }\end{array}$ & \\
\hline $\begin{array}{l}\text { [186] PÉREZ } \\
\text { DÍAZ, Dionisio } \\
\text { (1). MEX. } \\
\text { Biografiado } \\
\text { por Maneiro. }\end{array}$ & $\begin{array}{l}\text { Misionero y biógrafo. Residió en } \\
\text { Ravena. "Siempre, en América y en su } \\
\text { destierro en Italia, vivió con } \\
\text { ejemplaridad religiosa y fama de } \\
\text { santidad" (BJE, p. } 440) \text {. En } 1767 \text { era } \\
\text { ministro, consultor de casa y confesor } \\
\text { en el Colegio Máximo de México. } \\
\text { "Está sepultado en la iglesia del } \\
\text { colegio que fue de jesuitas en Ravena" } \\
(B J E, \text { p. } 440) \text {. }\end{array}$ & 10 . & $\begin{array}{l}\text { Jesuita desde 14-V-1749. Cuarto voto en } \\
\text { Guanajuato el 2-II-1765. "Nació de nobilísima } \\
\text { familia. Imprimió en la imprenta del colegio } \\
\text { jesuítico de S. Ildefonso de México, el 1763, la } \\
\left.\text { Vida del jesuita Pedro Borrote [n }{ }^{\circ} 29\right]^{\prime} \text {. Dávila y } \\
\text { Arrillaga habla de sus "hermossíssimos versos". } \\
\text { Según Félix de Sebastián fue un caritativo } \\
\text { pedagogo, venerado por los jóvenes de su } \\
\text { provincia }{ }^{63} \text {. }\end{array}$ & $\begin{array}{l}\text { *Veracruz, 9-X-1731- } † \text { Ravena, } \\
2-X I I-1772 .\end{array}$ \\
\hline $\begin{array}{l}\text { [384] PÉREZ } \\
\text { DÍAZ, Tomás } \\
\text { de (2). MEX. } \\
\text { Hermano de } \\
\text { Dionisio (n } \\
\text { 186). }\end{array}$ & $\begin{array}{l}\text { Teólogo. Residía en Roma en } 1794 \text {. En } \\
1767 \text { era prefecto de Iglesia y cárceles } \\
\text { en el Colegio de Veracruz. Félix de } \\
\text { Sebastián subraya su buena situación } \\
\text { económica: "No padecía necesidades, } \\
\text { pues un su caritativo hermano tuvo } \\
\text { siempre el cuidado de que estuviera } \\
\text { muy bien proveído, mandándole } \\
\text { continuos socorros desde la } \\
\text { América"64. }\end{array}$ & 5. & $\begin{array}{l}\text { Jesuita desde } 15-\mathrm{VIII}-1744 \text {. Cuarto voto en } \\
\text { Veracruz, el 2-II-1760. "Escribió: } 1 \text {. Tratado sobre } \\
\text { el misterio de la Concepción Inmaculada de María } \\
\text { Santísima. 2. Observaciones sobre el martirolojio } \\
\text { romano" (BJE, p. 652). }\end{array}$ & $\begin{array}{l}\text { *Veracruz, 5-X-1726- } \uparrow \text { Roma, } \\
\text { 10-I-1796. }\end{array}$ \\
\hline $\begin{array}{l}\text { [192] PEZA, } \\
\text { Nicolás (1). } \\
\text { MEX. } \\
\text { "Insigne en } \\
\text { piedad", fue } \\
\text { biografiado } \\
\text { por Maneiro. }\end{array}$ & $\begin{array}{l}\text { Filósofo. Residió en Bolonia. En } 1767 \\
\text { estaba en el Colegio de Valladolid de } \\
\text { Mechoacán, donde era admonitor, } \\
\text { prefecto de cárceles, director de } \\
\text { ejercicios y consultor de casa. Está } \\
\text { sepultado en la Iglesia Parroquial de } \\
\text { Santa María Magdalena de Bolonia } \\
\text { (Libro, VIII, 66). }\end{array}$ & 10 . & $\begin{array}{l}\text { Jesuita desde 17-I-1733. Cuarto voto, el 15-VIII- } \\
\text { 1748. "Enseñó la filosofía en México y en Puebla } \\
\text { de los Ángeles y la teología en Guadalajara, de } \\
\text { cuyo colegio fue rector. Imprimió: Homagium } \\
\text { quotidianum (México, 1755, Faenza, 1770" (BJE, } \\
\text { p. 447). Es uno de los muchos opúsculos ascéticos } \\
\text { que escribió y consiste en la homagia o fórmula de } \\
\text { afectos piadosos } 65 \text {. }\end{array}$ & $\begin{array}{l}\text { * México, 27-IX-1712- } \\
\text { †Bolonia, 17-IV-1777. }\end{array}$ \\
\hline
\end{tabular}

$\overline{{ }^{63} \text { Ibíd., 1767-1796, vol. I: 206-208. }}$

${ }^{64}$ Ibíd., 1767-1796, vol. II: 349.

${ }^{65}$ Ibíd., 1767-1796, vol. I: 296-301.

94 Antonio Astorgano Abajo y Fuensanta Garrido Domené. Panorama esquemático ... 60-120. 


\begin{tabular}{|c|c|c|c|c|}
\hline $\begin{array}{l}{[387]} \\
\text { POVEDA, } \\
\text { Mariano } \\
\text { Antonio (2). } \\
\text { MEX. } \\
\text { Parece que } \\
\text { retornó a } \\
\text { España entre } \\
1798 \text { y } 1801 .\end{array}$ & $\begin{array}{l}\text { Canonista y teólogo contrario el } \\
\text { emperador José II de Austria. En } 1767 \\
\text { estaba en el Seminario de Mérida de } \\
\text { Yucatán (maestro de aposentos y } \\
\text { retórica). Residente en Bolonia en } 1773 \\
\text { y después Tívoli y Roma ("Enseñó la } \\
\text { teología en los estudios públicos de la } \\
\text { ciudad de Tívoli y reside en la casa, } \\
\text { antes jesuítica, llamada Jesús en } \\
\text { Roma" (BJE, p. 654). }\end{array}$ & 10 . & $\begin{array}{l}\text { Jesuita desde el 1-VII-1750. Cuarto voto, el 13-XI- } \\
\text { 1768. "Escribió: } 1 \text {. De matrimoniis haereticorum } \\
\text { in Germania contractis, vel contrahendis sub } \\
\text { conditione solvendi matrimonium sub eventu } \\
\text { adulterii, vigentibus praesertim novissimis legibus } \\
\text { s. imperatoris Josep II. Libri duo. 2. Theologico- } \\
\text { canonica impugnatio cujusdam libri, cui titulus: } \\
\text { "Ecclesiastica, et civilis reformatio imperii } \\
\text { germanici catholici auspiciis, sanctissimisque } \\
\text { legibus aug. imperat. Josephi II" (BJE, p. 654). }\end{array}$ & $\begin{array}{l}\text { *La Habana, 3-XI-1734 (1731, } \\
\text { según Hervás)- †Roma, 7-II- } \\
1802 .\end{array}$ \\
\hline $\begin{array}{l}{[388] \text { PREEN, }} \\
\text { Dámaso (2). } \\
\text { ANDALUCÍA } \\
\text { y MEX. }\end{array}$ & $\begin{array}{l}\text { Confesor, matemático e historiador. } \\
\text { Reside en Roma. En } 1767 \text { era escolar } \\
\text { humanista en el noviciado de } \\
\text { Tepotzotlán. "Murió en Roma a } 19 \text { de } \\
\text { agosto de 1793. Está sepultado en la } \\
\text { iglesia llamada Jesús" (BJE, p. 655). } \\
\text { Félix de Sebastián destaca "su } \\
\text { aplicación a los libros morales, } \\
\text { ascéticos y teológicos"66. }\end{array}$ & 10 . & $\begin{array}{l}\text { Jesuita desde el 27-IV-1765. Se ordenó el 21-IX- } \\
1772 \text {."Estudió retórica, filosofía, matemáticas y } \\
\text { teología, y recibió el orden sacerdotal. Vivió en } \\
\text { sumo retiro de meditación santa y de estudio con } \\
\text { vida ejemplar, por lo que el cardenal vicario de esta } \\
\text { ciudad de Roma le nombró confesor perpetuo de un } \\
\text { convento de religiosas capuchinas. Escribió: } 1 . \\
\text { Obra cronolójica. Un tomo grueso en folio. } 2 \text {. } \\
\text { Instituciones de jeografia histórica. 3. Elementos de } \\
\text { jeometría y áljebra" (BJE, pp. 654-655). }\end{array}$ & $\begin{array}{l}\text { *Cádiz, 11-XII-1743 (según } \\
\text { Hervás, 1744)- †Roma, 19-VIII- } \\
1793 .\end{array}$ \\
\hline $\begin{array}{l}\text { [215] RIVERO } \\
\text { (RIBERO) } \\
\text { MARÍN, } \\
\text { Francisco } \\
\text { Javier (1). } \\
\text { MEX. } \\
\text { Biografiado } \\
\text { por Maneiro. }\end{array}$ & $\begin{array}{l}\text { Misionero y teólogo. Residió en } \\
\text { Bolonia. En } 1767 \text { estaba de capellán en } \\
\text { el Colegio Máximo San Pedro y San } \\
\text { Pablo de México. "Está sepultado en la } \\
\text { iglesia parroquial de Santa María } \\
\text { Magdalena de Bolonia" (BJE, p. } 485) \text {. } \\
\text { Fue ampliamente reseñado por Félix de } \\
\text { Sebastián, señalando su estricta } \\
\text { disciplina horaria, aunque con limitada } \\
\text { producción literaria }{ }^{67} \text {. }\end{array}$ & 10. & $\begin{array}{l}\text { Jesuita desde } 15 \text {-III-1749. Cuarto voto, el 2-II- } \\
\text { 1765. Maestro de gramática en Puebla. Operario y } \\
\text { maestro de aposentos en México. Sus superiores no } \\
\text { le consideraron apto para tareas de gobierno, por lo } \\
\text { que pasó varios años como capellán en haciendas. } \\
\text { "Nació de noble familia. Enseñó la latinidad en } \\
\text { Puebla de los Ángeles; y en los colegios de Méjico } \\
\text { se empleó con celo apostólico en prefecturas } \\
\text { espirituales y en instrucción de los indios. De vida } \\
\text { inocente y religiosamente ejemplar, vivió siempre } \\
\text { en retiro, meditación y práctica de virtudes. } \\
\text { Imprimió: En italiano, un Devocionario a los } \\
\text { nueve coros de Ángeles (Ravena, 1775). Dejó }\end{array}$ & $\begin{array}{l}\text { *Valladolid de Michoacán, } \\
\text { 3-XII-1729-†Bolonia, 17-II- } \\
\text { 1787. }\end{array}$ \\
\hline
\end{tabular}

${ }^{66}$ Ibíd., 1767-1796, vol. II: 245.

${ }^{67}$ Ibíd., 1767-1796, vol. II: 59.

95 Antonio Astorgano Abajo y Fuensanta Garrido Domené. Panorama esquemático ... 60-120. 


\begin{tabular}{|c|c|c|c|c|}
\hline & & & $\begin{array}{l}\text { manuscrito y concluido un tomo sobre la } \\
\text { Inmaculada Concepción de María Santísima" (BJE, } \\
\text { p. } 485) \text {. }\end{array}$ & \\
\hline $\begin{array}{l}\text { [395] ROSET, } \\
\text { Juan (2). } \\
\text { ARAGÓN, } \\
\text { QUITO y } \\
\text { MEX. }\end{array}$ & $\begin{array}{l}\text { Historiador y traductor de otros jesuitas } \\
\text { (Andrés Marcos Burriel, Scaramelli, } \\
\text { Roberto Belarmino...) y de Feijoo. En } \\
1767 \text { estaba en el Colegio San José de } \\
\text { La Habana, siendo prefecto de Dolores } \\
\text { y Buena Muerte. Residió en Roma, } \\
\text { según Hervás. Protegido del arzobispo } \\
\text { de Guatemala, Francisco de Figueredo, } \\
\text { al que acompañó en diversos destinos y } \\
\text { provincias jesuíticas. En } 1766 \text { publicó } \\
\text { su Sermón fúnebre, por lo que Roset } \\
\text { debería ir en el Catálogo I de la } B J E .\end{array}$ & 20. & $\begin{array}{l}\text { Jesuita desde 24-XI-1741. Cuarto voto, el 2-II- } \\
\text { 1756. Habiendo traducido al italiano la Historia de } \\
\text { la California del P. Burriel, "y habiendo estampado } \\
\text { ya el mapa de California y algunas láminas, en que } \\
\text { se representaban los californios, los animales de su } \\
\text { península, \&c., D. Josef de Gálvez, secretario de } \\
\text { Indias en Madrid, ordenó al duque de Grimaldi, } \\
\text { ministro español en Roma [1777-1784], que al } \\
\text { autor intimase la suspensión de la edición de su } \\
\text { Historia, de que envió a Madrid un ejemplar } \\
\text { manuscrito. Escribió: 1. Historia de la California } \\
\text { en idioma italiano. Traducción de las obras } \\
\text { siguientes en español: 2. Guía de los hombres a la } \\
\text { salud eterna. Obra de jesuita Roberto Personio } \\
\text { [Parsons o Persons]. 3. Discernimiento del espiritu. } \\
\text { Obra del jesuita Scramelli [Scaramelli]. } 4 \text {. } \\
\text { Traducción al español y al italiano de la obra del } \\
\text { cardenal Roberto Belarmino, intitulada: "De } \\
\text { ascensione mentis in Deum". 5. Traducción al } \\
\text { italiano de los mejores discursos de Benito Feijoo, } \\
\text { del orden de San Benito. 6. Della maniera, con cui i } \\
\text { saraceni s'impadronirono della Spagna e ne furono } \\
\text { scacciati" (BJE, pp. 660-662). }\end{array}$ & $\begin{array}{l}\text { * Gimerá (España), 16-III-1718- } \\
\text { †Bolonia, 20-IX-1794 (76 años, } \\
\text { San Mamolo, IX,12). }\end{array}$ \\
\hline $\begin{array}{l}{[400]} \\
\text { SEBASTIÁN } \\
\text { PIÓN, Félix } \\
\text { José de (2). } \\
\text { AN y MEX. }\end{array}$ & $\begin{array}{l}\text { Importante cronista y biógrafo de } \\
\text { jesuitas mexicanos. Residió en } \\
\text { Bolonia. Misionero en Chinipas } \\
\text { (Tubares) en junio de } 1767 \text {. Está } \\
\text { enterrado en el cementerio de la } \\
\text { Cartuja de Bolonia. }\end{array}$ & 5. & $\begin{array}{l}\text { Suscriptor de Idea dell 'Universo. Jesuita desde 5- } \\
\text { IX-1754. El prudente Hervás sólo enumera el } \\
\text { manuscrito, Menolojio de los jesuitas y exjesuitas } \\
\text { de la provincia mejicana muertos fuera de los } \\
\text { dominios españoles, sin ningún comentario (BJE, p. } \\
\text { 666). No parece que Hervás tomase dicho } \\
\text { manuscrito como fuente de su } B J E^{68} \text {. }\end{array}$ & $\begin{array}{l}\text { *San Lúcar de Barrameda, } \\
27-X I I-1736-\uparrow \text { Bolonia, 29-VI- } \\
1815 .\end{array}$ \\
\hline
\end{tabular}

${ }^{68}$ Ibíd., 1767-1796.

96 Antonio Astorgano Abajo y Fuensanta Garrido Domené. Panorama esquemático ... 60-120. 


\begin{tabular}{|c|c|c|c|c|}
\hline $\begin{array}{l}{[493]} \\
\text { SEDELMAYER } \\
\text { SOTOMAYOR, } \\
\text { Santiago } \\
\text { [Jaime, } \\
\text { Jacobo] (4). } \\
\text { ALEMANIA } \\
\text { y MEX. }\end{array}$ & $\begin{array}{l}\text { Misionero y explorador. En } 1767 \\
\text { estaba en la misión de Matapé } \\
\text { (Sonora). Fue uno de los jesuitas } \\
\text { rehenes de Carlos III, prisionero en el } \\
\text { Puerto de Santa María y después (julio } \\
\text { de } 1775 \text { ) en Salamanca. Según Hervás, } \\
\text { "murió después de } 1788^{\prime} \text { "). Félix de } \\
\text { Sebastián no pudo conocerlo, por lo } \\
\text { que nos ha dejado una vaga } \\
\text { necrológica de Sedelmayer, resaltando } \\
\text { sus cualidades de misionero y el arresto } \\
\text { en Cádiz }{ }^{69} \text {. }\end{array}$ & 5. & $\begin{array}{l}\text { Jesuita desde } 7-\mathrm{X}-1722 \text {, embarcó para México en } \\
1735 \text {. Cuarto voto, el } 1^{\circ} \text {-V-1740. Además de un } \\
\text { diccionario sobre la lengua pima, "escribió } \\
\text { relaciones de la Pimería y Sobaipuris, que quedaron } \\
\text { en América con los mapas que había formado de la } \\
\text { provincia de sus misiones" (BJE, p. } 760 \text { ), } \\
\text { publicadas la mayor parte por J. M. Andrade en } \\
\text { Documentos para la Historia de México. Tercera } \\
\text { serie (México, 1856). }\end{array}$ & $\begin{array}{l}\text { *Inhausen (Baviera), } 6 \text { (otros, } \\
\text { 12)-I-1703- †Aldea Dávila } \\
\text { (Salamanca), 9-II-1778 (Zelis, } \\
\text { 12-II-1779). }\end{array}$ \\
\hline $\begin{array}{l}{[494]} \\
\text { TARAVAL } \\
\text { ANDRADE, } \\
\text { Segismundo } \\
\text { (4). TOLEDO } \\
\text { y MEX. No } \\
\text { fue expulso. }\end{array}$ & $\begin{array}{l}\text { Misionero e historiador de California. } \\
\text { Hombre original, simpático, celoso y } \\
\text { eficaz. "Hijo del teniente general, D. } \\
\text { Miguel Taraval, [...] se empleó con } \\
\text { celo apostólico en las misiones de } \\
\text { California. [...] El 1751, por } \\
\text { obediencia, dejó las misiones de } \\
\text { California y fue a Guadalajara, en } \\
\text { donde permaneció hasta el año de su } \\
\text { muerte. Taraval fue varón insigne en } \\
\text { virtud y sabiduría" (BJE, pp. 760-762). } \\
\text { A Hervás se le escapa la apología } \\
\text { dedicada a la Santa Cruz de Zacate, } \\
\text { titulada, "El milagro más visible...."70. }\end{array}$ & 10 . & $\begin{array}{l}\text { Estuvo a punto de ser martirizado en la rebelión } \\
\text { india de 1734. Jesuita desde 31-X-1718. Cuarto } \\
\text { voto el 16-VIII-1737 en San José del Cabo (Baja } \\
\text { California Sur, México). "Escribió doctrinas } \\
\text { morales para instrucción de los californios" (BJE, } \\
\text { pp. 760-762). Escribió obras de carácter pastoral, } \\
\text { catequético y geográfico. Destaca su Historia de las } \\
\text { misiones de la California Baja, que además de } \\
\text { proporcionar otras informaciones importantes, } \\
\text { constituye un material indispensable para historiar } \\
\text { la insurrección de 1734-1737 y que ha sido } \\
\text { inteligentemente aprovechado por historiadores } \\
\text { jesuitas, como Miguel del Barco (1706-1790), } \\
\text { Francisco J. Clavigero (n }{ }^{\circ} \text { 50) y Miguel Venegas } \\
\text { (1680-1764). }\end{array}$ & $\begin{array}{l}\text { *Lodi (Milán), 27-X-1700- } \\
\text { †Guadalajara (México), } 11 \\
1763 .\end{array}$ \\
\hline $\begin{array}{l}\text { [239] TOLEDO } \\
\text { GuTIÉRREZ, } \\
\text { Josef Ángel }\end{array}$ & $\begin{array}{l}\text { Predicador. Reside en Roma. } \\
\text { Repasante de Filosofía en } 1767 \text { en el } \\
\text { Colegio de San Ildefonso de Puebla de } \\
\text { los Ángeles. Escribió sobre el culto al }\end{array}$ & 10 . & $\begin{array}{l}\text { Suscriptor a la enciclopedia de Idea dell'Universo. } \\
\text { Jesuita desde } 18 \text {-II-1763. Ordenado el 22-IX-1770. } \\
\text { "Imprimió: 1. Por encargo de las religiosas } \\
\text { capuchinas de Guatemala, escribió un devocionario }\end{array}$ & $\begin{array}{l}\text { *Guatemala, 10-II-1744- } \\
\text { †Cremona, 1824. }\end{array}$ \\
\hline
\end{tabular}

${ }^{69}$ Ibíd., 1767-1796, vol. I: 338; Dunne, 1937: 19-37; Montané Martí, 1999; Pradeau, 1959.

${ }^{70}$ Biblioteca Nacional de Madrid, mss. 20360. "El milagro más visible o el milagro de los milagros más patente. La Santísima Cruz de Tepique. Descripción histórica de su situación, materia, forma, medidas y demás circunstancias que la forman". Dedicada a D. Francisco López Portillo, del Consejo de S. M. Oidor en la Audiencia de Guadalaxara.

97 Antonio Astorgano Abajo y Fuensanta Garrido Domené. Panorama esquemático ... 60-120. 


\begin{tabular}{|c|c|c|c|c|}
\hline (1). MEX. & $\begin{array}{l}\text { Sagrado Corazón de Jesús, a la Virgen } \\
\text { del Refugio en Guatemala y a la de } \\
\text { Guadalupe. }\end{array}$ & & $\begin{array}{l}\text { a la Virgen María con el título del Refujio; y en } \\
\text { Guatemala se publicó el 1787. 2. Triduo in ossequio } \\
\text { di María Santissima di Guadalupe del Messico } \\
\text { colla storia della sua apparizione (Roma, 1787). } \\
\text { Manuscritos: Día feliz en honra del Sagrado } \\
\text { Corazón de Jesús [publicado en Bolonia en 1790, } \\
\text { con numerosas ediciones posteriores]" (BJE, p. } \\
\text { 531). }\end{array}$ & \\
\hline $\begin{array}{l}{[418]} \\
\text { TRUXILLO, } \\
\text { Joaquín (2). } \\
\text { MEX. }\end{array}$ & $\begin{array}{l}\text { Humanista. En } 1767 \text { estaba en el } \\
\text { Colegio del Espíritu Santo de Puebla } \\
\text { (prefecto de catequismo). Residió en } \\
\text { Faenza }^{71} \text {. }\end{array}$ & 5. & $\begin{array}{l}\text { Jesuita desde } 30 \text {-VIII-1745. Cuarto voto, el 4-X- } \\
\text { 1761. "Escribió: Método para hallar la lonjitud. El } \\
\text { autor presentó en Roma esta obra manuscrita al } \\
\text { conde de Floridablanca" (BJE, pp. 679-680). }\end{array}$ & $\begin{array}{l}\text { *Fresnillo (Guadalaxara), 29- } \\
\text { IV-1726-†Faenza, } 21 \text { (Hervás, } \\
\text { 22)-II-1775. }\end{array}$ \\
\hline $\begin{array}{l}{[432]} \\
\text { URBIOLA } \\
\text { EZPELETA, } \\
\text { Josef (2). } \\
\text { TOLEDO y } \\
\text { MEX. } \\
\text { Biografiado } \\
\text { por Maneiro. }\end{array}$ & $\begin{array}{l}\text { Moralista. Residió en Bolonia. En } \\
1746, \text { ya sacerdote, embarcó para } \\
\text { México. Residió muchos años en Cuba, } \\
\text { como profesor, operario y rector del } \\
\text { Colegio de La Habana (1761), siendo } \\
\text { felicitado por su defensa de la ciudad } \\
\text { contra los ataques de Inglaterra. Figura } \\
\text { central en la expulsión de los jesuitas } \\
\text { de Tepotzotlán, pues era rector y } \\
\text { maestro de novicios en 1767. "Varón } \\
\text { de virtud heroica y de singular } \\
\text { inocencia". Está enterrado en la iglesia } \\
\text { de Santa María Magdalena de Bolonia } \\
\text { (Libro VIII, 188). }\end{array}$ & 10. & $\begin{array}{l}\text { El } 14 \text { de mayo de } 1735 \text { se incorporó al noviciado en } \\
\text { Madrid. El } 15 \text { de Agosto de } 1752 \text { hizo su } \\
\text { profesión solemne y tres años más tarde lo } \\
\text { nombraron Superior en la residencia de Puerto } \\
\text { Príncipe. Dejó manuscritos: "l. Doctrina cristiana. } \\
\text { Un tomo en folio. 2. Diversos opúsculos de } \\
\text { devoción" (BJE, p. 691). Félix de Sebastián } \\
\text { especifica: "En Bolonia su ocupación continua era } \\
\text { orar, meditar, rezar y escribir en su aposento sobre } \\
\text { el Amor Divino, de que nos dejó excelentes } \\
\text { manuscritos, que todos respiran piedad”. En las } \\
\text { notas que se hacen de su personalidad, se señala } \\
\text { que es “...de ingenio, juicio, prudencia y letras, } \\
\text { bueno; de suficiente experiencia; de complexión } \\
\text { temperada; de talento para todo"72. }\end{array}$ & $\begin{array}{l}\text { * Peralta (Navarra, España), 8- } \\
\text { V-1714 (Hervás, 1713)- } \\
\text { †Bolonia, 29-VII-1783. Está } \\
\text { enterrado en la iglesia de Santa } \\
\text { María Magdalena de Bolonia } \\
\text { (Libro VIII, 188). }\end{array}$ \\
\hline $\begin{array}{l}{[248]} \\
\text { VALLARTA Y } \\
\text { PALMA, José } \\
\text { Mariano (1). } \\
\text { MEX. Usó los }\end{array}$ & $\begin{array}{l}\text { Pedagogo, filósofo y teólogo. En } 1767 \\
\text { estaba en el Colegio Máximo San } \\
\text { Pedro y San Pablo de México. Reside } \\
\text { en Bolonia. "Nació de nobilísima } \\
\text { familia [...], con singular aplicación }\end{array}$ & 20 . & $\begin{array}{l}\text { Jesuita desde } 27 \text { (Hervás, 26)-X-1734. Cuarto voto, } \\
\text { el } 15 \text {-VIII-1752. En México escribió sobre retórica } \\
\text { y poesía. En el exilio defendió la infalibilidad de la } \\
\text { Iglesia Romana y la Bula Unigenitus. "Imprimió: } \\
\text { 1. Compendium rethoricae et poesiae. Mexici, }\end{array}$ & $\begin{array}{l}\text { * Puebla de los Ángeles, 18- } \\
\text { VII-1719-†Bolonia, 31-VII- } \\
1790 .\end{array}$ \\
\hline
\end{tabular}

\footnotetext{
${ }^{71}$ Según Félix de Sebastián, «ocupaba siempre su descompuesta fantasía en escribir». Sebastián, 1767-1796, vol. I: 251.

${ }^{72}$ Astorgano Abajo, 2009g:147-149. Sebastián, 1767-1796, vol. I: 449-457.
}

98 Antonio Astorgano Abajo y Fuensanta Garrido Domené. Panorama esquemático ... 60-120. 


\begin{tabular}{|c|c|c|c|c|}
\hline $\begin{array}{l}\text { seudónimos de } \\
\text { "José Luis, } \\
\text { sacerdote", } \\
\text { "Julián Poncio } \\
\text { [Ponce], } \\
\text { Sacerdote", } \\
\text { "José } \\
\text { Travallae" y } \\
\text { "Ennodius } \\
\text { Faventinus". } \\
\text { Biografiado } \\
\text { por Maneiro. }\end{array}$ & $\begin{array}{l}\text { estudió filosofía, teología y sagrados } \\
\text { cánones. [...] En Méjico, interpretó la } \\
\text { Sagrada Escritura, sucediendo al } \\
\text { ejemplar y sabio jesuita doctor Javier } \\
\text { Lazcano [nº 122], su maestro, a quien } \\
\text { después, en el 1762, sucedió también } \\
\text { en la cátedra teológica [la de Suárez, } \\
\text { hasta la expulsión a Italia] de la } \\
\text { universidad de Méjico". Enseñó a sus } \\
\text { compañeros de destierro el italiano, } \\
\text { que había aprendido con su profesor de } \\
\text { humanidades, el P. Quingles. En Italia } \\
\text { enseñó teología hasta que la Compañía } \\
\text { fue extinguida. Pasó a Roma en 1775 } \\
\text { para saludar al Padre Santo y murió } \\
\text { ciego. Está sepultado en la iglesia } \\
\text { parroquial de Santa María Magdalena } \\
\text { (Libro IX, 62). }\end{array}$ & & $\begin{array}{l}\text { Patre Petro Maria La-Torre e Societate Jesu, olim } \\
\text { elaboratae: nunc vero a P...]. Esta obra se ha } \\
\text { reimpreso en Bolonia [1784] para uso de las } \\
\text { escuelas públicas, que en dicha ciudad se llaman } \\
\text { Scuole-Pie. 2. Ecclesia romana infallibilis in } \\
\text { factorum definitionibus. Roma, 1777. 3. Juliani } \\
\text { Poncii ad Christianum Philadelphum de cuniculis } \\
\text { philosophorum epistolae. Lucae, 1779. Quizá el } \\
\text { señor Vallarta se llamaba Julián de segundo } \\
\text { nombre y Ponce de segundo apellido; y por esto, } \\
\text { queriendo ocultarse, se llamó Julián Ponce. } 4 . \\
\text { Confutazione del paralello tra le proposizioni } \\
\text { condannate nella Bolla "Unigenitus", ed alcune } \\
\text { della sagra scrittura, e de' santi padri, che leggesi } \\
\text { in un libro anatematizzato. 5. Opúsculo sobre el } \\
\text { célebre abad Joaquín, impreso en Imola" (BJE, pp. } \\
\text { 539-540). Beristáin hace cabal elogio del excelente } \\
\text { humanista y filósofo cuya sutil inteligencia y vida } \\
\text { austera eran un ejemplo. Reseña las obras } \\
\text { publicadas en México, omitidas en Hervás, como } \\
\text { Instrucción para hacer una buena confesión, } \\
\text { México, 1758; Carta de consuelo, que a D. Antonio } \\
\text { Zabala escribió el P..., México, 1762. Por su parte } \\
\text { Félix de Sebastián concluye: "todo el tiempo que } \\
\text { vivió en la Italia lo pasó con los libros y la puma en } \\
\text { la mano, defendiendo siempre en sus escritos la fe } \\
\text { católica contra los herejes y libertinos"73. }\end{array}$ & \\
\hline $\begin{array}{l}{[249]} \\
\text { VALLEJO, } \\
\text { Josef Ignacio } \\
\text { (1). MEX. }\end{array}$ & $\begin{array}{l}\text { Biógrafo y poeta. Residió en Bolonia. } \\
\text { En } 1767 \text { era catedrático de Prima de } \\
\text { Teología en Guatemala. "La ciudad de } \\
\text { Guatemala fue teatro, casi perpetuo, de } \\
\text { la enseñanza literaria y de los } \\
\text { ministerios apostólicos del señor } \\
\text { Vallejo, que siempre vivió en el mayor } \\
\text { retiro, procurando adelantar en la } \\
\text { escuela de la virtud y de las ciencias, }\end{array}$ & 20. & $\begin{array}{l}\text { Amigo de Hervás, quien colaboró en su Vida de } \\
\text { San Josef, insertando una carta. Esteban Terreros y } \\
\text { Pando (n }{ }^{\circ} \text { 238) califica al P. Vallejo de "sabio". } \\
\text { Jesuita desde 3-V-1741. Cuarto voto, el 27-IV- } \\
\text { 1755. Maestro de Retórica en México, Chiapa y } \\
\text { Guatemala. En Bolonia redactó tratados espirituales } \\
\text { y de devoción, algunos traducidos del italiano sobre } \\
\text { la vida de San José, La Virgen, San Joaquín y Santa } \\
\text { Ana, casi todos publicados en la imprenta de }\end{array}$ & $\begin{array}{l}\text { *Jalostotitlan (Jalisco), } 9 \text { (según } \\
\text { Hervás, 29) -IX-1718) - } \\
\text { †Bolonia, 30-V-1785 (67 años, } \\
\text { Santa María de la Piedad, Un. } \\
\text { A.d.). }\end{array}$ \\
\hline
\end{tabular}

\footnotetext{
$\overline{{ }^{73} \text { Sebastián, 1767-1796, vol. II: } 162 .}$
}

99 Antonio Astorgano Abajo y Fuensanta Garrido Domené. Panorama esquemático ... 60-120. 


\begin{tabular}{|c|c|c|c|c|}
\hline & $\begin{array}{l}\text { principalmente sagradas. [...] La } \\
\text { sinceridad, honradez y humildad le } \\
\text { eran características. En Italia vivió } \\
\text { como podría estar en el mayor desierto } \\
\text { de América. Su casa eran las iglesias y } \\
\text { el retrete de su habitación" (BJE, p. } \\
\text { 541). Félix de Sebastián nos especifica } \\
\text { la vocación literaria de Vallejo en el } \\
\text { destierro: "No pudiendo su genio } \\
\text { laborioso contenerse en los pocos } \\
\text { quehaceres de la Italia, lo llevó su } \\
\text { devoción a emplearse en escribir varios } \\
\text { tratados espirituales y santos. [...]. } \\
\text { Déjanse conocer en estos partos de su } \\
\text { devoción lo tierno de su espíritu, lo } \\
\text { cándido de su ánimo, lo docto de su } \\
\text { pluma y lo extendido de su } \\
\text { erudición» }{ }^{74} \text {. }\end{array}$ & & $\begin{array}{l}\text { Gregorio Bisini de Cesena, de la que Hervás era } \\
\text { asesor literario. "Imprimió: 1. Vida de San Josef. } \\
\text { Cesena, 1774. Por Gregorio Biasini. 2. Vida de San } \\
\text { Josef (segunda edición [corregida y aumentada, } \\
\text { Cesena, Biasini, 1779]) y Vida de San Joaquín y } \\
\text { Santa Ana. Cesena, 1779. Por Gregorio Biasini. } 4^{\circ} \text {. } \\
\text { 3. Vida de la Madre de Dios, la Virgen Santísima. } \\
\text { Cesena, } 1779 . \text { Por Gregorio Biasini. } 4^{\circ} \text {. } 4 \text {. Un } \\
\text { devocionario de San Josef. } 8^{\circ} \text {. 5. Retrato fiel de la } \\
\text { noble ciudad de Santiago de Guatemala en } 37 \\
\text { décimas y } 9 \text { octavas. En Cesena. Por Gregorio } \\
\text { Biasini, 1772. } 8^{\circ} \text {. Dejó manuscrito: Un compendio } \\
\text { de las célebres obras canónicas de González" (BJE, } \\
\text { pp. 541-542). Beristaín añade el Elogio fúnebre del } \\
\text { Ilmo. Sr. Dr. D. Francisco Figueredo, arzobispo de } \\
\text { Guatemala, México, } 1766 .\end{array}$ & \\
\hline $\begin{array}{l}\text { [256] } \\
\text { VILLAFAÑE, } \\
\text { Cristóbal (1). } \\
\text { MEX. No fue } \\
\text { expulso. } \\
\text { Biografiado } \\
\text { por el jesuita } \\
\text { chileno } \\
\text { Joaquín } \\
\text { Lacunza. }\end{array}$ & $\begin{array}{l}\text { Poeta, periodista y operario. Murió en } \\
\text { Guatemala asesinado por unos } \\
\text { condenados a los que confesaba en } \\
1766 .\end{array}$ & 10 . & $\begin{array}{l}\text { Jesuita desde 13-XI-1749. "Imprimió en } \\
\text { Guatemala, en la imprenta de Joaquín de Arévalo, } \\
\text { diversas poesías en honor de la Inmaculada } \\
\text { Concepción de María Santísima. Asimismo } \\
\text { imprimió varios folios periódicos con las noticias } \\
\text { más importantes que ofrecían los actuales sucesos } \\
\text { en Guatemala” (BJE, p. 552). }\end{array}$ & $\begin{array}{l}* \text { Ciudad de México, 25-VII- } \\
\text { 1731-†Guatemala, 28-VIII- } \\
1766 .\end{array}$ \\
\hline $\begin{array}{l}{[438]} \\
\text { ZEVALLOS } \\
\text { (CEBALLOS) } \\
\text { MARTÍNEZ, } \\
\text { Francisco } \\
\text { Javier de (2). }\end{array}$ & $\begin{array}{l}\text { Provincial. Teólogo. Residió en } \\
\text { Bolonia. En } 1767 \text { era rector en el } \\
\text { colegio de San Andrés de México. Está } \\
\text { sepultado en la Iglesia de San Ignacio } \\
\text { de Bolonia. }\end{array}$ & 10 . & $\begin{array}{l}\text { Jesuita desde 1-VI-1720. Cuarto voto, el 15-VIII- } \\
1739 \text {. Fue el antepenúltimo Provincial de México, } \\
\text { impulsando la modernización de los estudios. } \\
\text { Hervás se limita decir que escribió "un curso casi } \\
\text { entero de teolojía. Esta obra quedó en Méjico" } \\
\text { (BJE, pp. 695-696). Es calificado por Félix de }\end{array}$ & $\begin{array}{l}\text { * Antequera (Oaxaca, México), } \\
7 \text { (13 según Hervás)-X-1704- } \\
\text { †Bolonia, 27-II-1770. }\end{array}$ \\
\hline
\end{tabular}

\footnotetext{
${ }^{74}$ Ibíd., 1767-1796, vol. I: 532.
}

100 Antonio Astorgano Abajo y Fuensanta Garrido Domené. Panorama esquemático ... 60-120. 


\begin{tabular}{|c|c|c|c|c|}
\hline $\begin{array}{l}\text { MEX. } \\
\text { Biografiado } \\
\text { por Maneiro. }\end{array}$ & & & $\begin{array}{l}\text { Sebastián como sabio y santo que visitó dos veces } \\
\text { la provincia }{ }^{75} \text {. }\end{array}$ & \\
\hline $\begin{array}{l}{[264] \text { Zuazu }} \\
\text { (Zuazo) } \\
\text { Ramírez, } \\
\text { Vicente (1). } \\
\text { MEX. }\end{array}$ & $\begin{array}{l}\text { Latinista y biógrafo. En } 1767 \text { era padre } \\
\text { operario en la Casa Profesa de México. } \\
\text { Residió en Ferrara. }\end{array}$ & 5. & $\begin{array}{l}\text { Jesuita desde 19-IV-1736. Cuarto voto, el 15-VIII- } \\
\text { 1752. "Imprimió en Ferrara muchos elogios de S. } \\
\text { Ignacio de Loyola y de S. Vicente Ferrer, en idioma } \\
\text { español, y algunos epigramas latinos" (BJE, p. } \\
\text { 560). Según Félix de Sebastián, "compuso varias } \\
\text { poesías latinas y españolas que dio a la estampa } \\
\text { para promover la devoción de estos dos santos"76. }\end{array}$ & $\begin{array}{l}\text { *Patzcuaro, 20-IV- } 1719 \\
\dagger \text { Ferrara, 17-I-1781. }\end{array}$ \\
\hline
\end{tabular}

\footnotetext{
${ }^{75}$ Ibíd., 1767-1796, vol. I: 154-159.

${ }^{76}$ Ibíd., 1767-1796, vol. I: 389-391.
}

101 Antonio Astorgano Abajo y Fuensanta Garrido Domené. Panorama esquemático ... 60-120. 


\section{TABLA-RESUMEN, $\mathbf{N}^{\circ} 2$}

Tabla-resumen de los literatos ex-jesuitas mexicanos que no aparecen en de la Biblioteca jesuítico-española de Hervás. Total 44 autores.

\begin{tabular}{|c|c|c|c|}
\hline $\begin{array}{l}\text { - Provincia jesuítica } \\
\text { (Alemania= ALE; } \\
\text { Aragón }=\text { AR; } \\
\text { Andalucía }=\text { AND; } \\
\text { Castilla }=\text { CAS; } \\
\text { Toledo=TO; } \\
\text { México=MEX; } \\
\text { Chile }=\text { CH; } \\
\text { Paraguay }=\text { PAR. }\end{array}$ & $\begin{array}{l}\text { - Actividad principal. } \\
\text {-Lugar de residencia en México } \\
\text { en } 1767 \text { y } 1773 . \\
\text { - Ciudad italiana de mayor } \\
\text { residencia hasta la redacción de } \\
\text { la Biblioteca de Hervás. } \\
\text {-Observaciones biográficas. }\end{array}$ & $\begin{array}{l}\text { Col=Colaborador de Hervás o citado en otras obras por él. } \\
\text { Suscr=Suscriptor a Idea dell'Universo. } \\
\text { - Corresp=Aludido en la correspondencia de Hervás. } \\
\text { Detall=Detalles que denotan trato con Hervás, especial } \\
\text { interés de éste. } \\
\text { Grado y actividades dentro de la Compañía. } \\
\text { Producción literaria publicada y manuscrita de cada } \\
\text { jesuita. }\end{array}$ & $\begin{array}{l}\text {-Fechas de nacimiento }(*) \text { y } \\
\text { muerte }(\dagger) \text {. } \\
\text {-Otras observaciones. }\end{array}$ \\
\hline $\begin{array}{l}\text { ÁGREDA LÁZARO, } \\
\text { Antonio de. } \\
\text { ARAGÓN y MÉX. }\end{array}$ & $\begin{array}{l}\text { Misionero y lingüista. En } 1767 \text { era } \\
\text { admonitor, confesor y prefecto de } \\
\text { Espíritu y Dolores en el Colegio de } \\
\text { San Luís de la Paz. Fue uno de los } \\
\text { seis jesuitas que fueron procesados } \\
\text { por la Inquisición novohispana por } \\
\text { el delito de solicitación } 77 \text {. Residió } \\
\text { en Castel San Pietro (Bolonia), pero } \\
\text { "acaecida la supresión, se pasó a } \\
\text { vivir a la vecina ciudad de Ímola", } \\
\text { según Félix de Sebastián" }\end{array}$ & 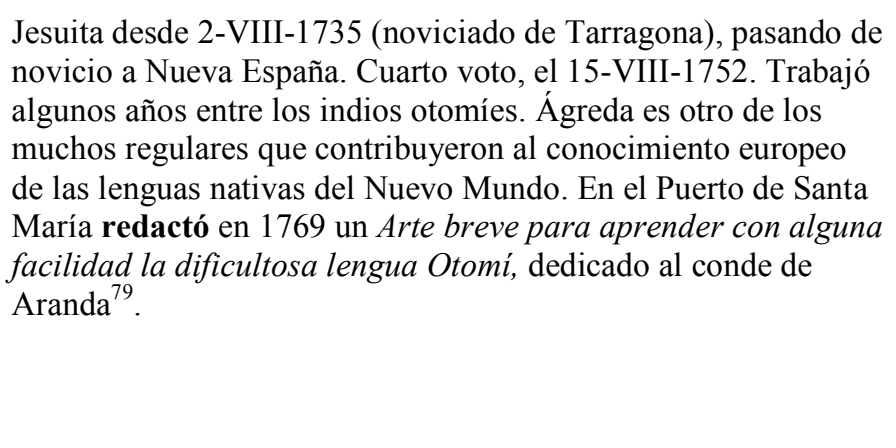 & $\begin{array}{l}\text { *Torrijos de la Cañada } \\
\text { (Zaragoza), 9-II-1714- †Ímola, } \\
\text { 30-I- } 1785 \text { (otros, 2-II-1785). }\end{array}$ \\
\hline $\begin{array}{l}\text { ALEGRE CAPETILLO, } \\
\text { Francisco Javier. } \\
\text { Estaba en la parte } \\
\text { dañada del Catálogo }\end{array}$ & $\begin{array}{l}\text { Historiador y humanista. Prefecto } \\
\text { de letras humanas en el Seminario } \\
\text { de San Ildefonso de México en } \\
1767 \text { (el rector era Parreño) e }\end{array}$ & $\begin{array}{l}\text { Jesuita desde 19-III-1747. Cuarto voto en } 15 \text {-VIII-1763. Es } \\
\text { conocida su Historia de la Provincia de la Compañia de Jesús } \\
\text { de Nueva España. Una primera versión fue secuestrada en } 1767 \text {, } \\
\text { pero la definitiva ya estaba concluida en } 1771 \text {. Alegre concedió }\end{array}$ & $\begin{array}{l}* \text { Veracruz, 12-XI-1729- } \dagger \text { Castel } \\
\text { San Pietro (Bolonia), 16-VIII- } \\
1788 .\end{array}$ \\
\hline
\end{tabular}

\footnotetext{
${ }^{77}$ Saint Clair Segurado, 2005: 55.

${ }^{78}$ Sebastián, 1767-1796, vol. I: 506-508.

${ }^{79}$ Uriarte, J. E. de y Lecina, M., 1925-1930, vol. I: 37.
} 


\begin{tabular}{|c|c|c|c|}
\hline $\begin{array}{l}\text { I. MEX. Importante. } \\
\text { Biografiado por } \\
\text { Manuel Fabri }\left(\mathrm{n}^{\mathrm{o}} 70\right)\end{array}$ & $\begin{array}{l}\text { historiador de la Provincia. Estaba } \\
\text { en Bolonia en 1773. Residió en } \\
\text { Castel San Pedro, Bolonia, Ferrara } \\
\text { y Fano. Curiosamente, Félix de } \\
\text { Sebastián, en contra de su } \\
\text { costumbre, reseña una larga lista de } \\
\text { títulos del P. Alegre, "en las más } \\
\text { diversas materias" } 80 \text {. }\end{array}$ & $\begin{array}{l}\text { más atención a los individuos que a la Compañía misma. Al } \\
\text { contrario que Clavigero, el indio es un personaje secundario en } \\
\text { la obra de Alegre, y tan sólo parece adquirir importancia en } \\
\text { tanto que circunstancia indispensable para que los jesuitas } \\
\text { alcancen la virtud cristiana. La obra abarca doscientos años de } \\
\text { la historia del Instituto, pero Alegre desarrolló con mayor } \\
\text { amplitud los períodos antiguos. Otras obras de Alegre, según } \\
\text { Manuel Fabri, son las Instituciones Teológicas }{ }^{81} \text { y De arte } \\
\text { rethórica synopssi; una Biblioteca Crítica no terminada, y una } \\
\text { recopilación de las leyes de Castilla }\end{array}$ & \\
\hline $\begin{array}{l}\text { ANAYA, José Lucas. } \\
\text { MEX. }\end{array}$ & $\begin{array}{l}\text { Misionero. Aprendió las lenguas } \\
\text { mexicana y otomí. Dedicó toda su } \\
\text { vida a la instrucción de indios. En } \\
1767 \text { se hallaba convaleciente en el } \\
\text { colegio de San Andrés de México. } \\
\text { Fue trasladado al hospital de San } \\
\text { Antonio Abad, donde murió, datos } \\
\text { confirmados por Félix de } \\
\text { Sebastián }{ }^{83} \text {. }\end{array}$ & $\begin{array}{l}\text { Jesuita desde 9-X-1739. Cuarto voto, 2-II-1754. Superior del } \\
\text { Seminario de Indios de San Martín (1761), conforme al catálogo } \\
\text { de ese año. Beristáin dice que, hallándose enfermo, no se le } \\
\text { expulsó en 1767. Publicó: } 1 \text {. Descenso y humillación de Dios } \\
\text { para el ascenso y exaltación del hombre, México, 1769. } 2 \text {. El } \\
\text { siglo de oro; padrón inmortal que por las súplicas de la nación } \\
\text { española y la piedad del augusto Carlos III levantó a la } \\
\text { Concepción Inmaculada de María el santo Padre Clemente } \\
\text { XIII, Puebla, 1763, y Gloriosa reducción que consiguió S. } \\
\text { Ignacio de Loyola de un lascivo mancebo de París, México, } \\
\text { 1767. Manuscritos: La verdadera metamorfosis, en que las } \\
\text { rosas de la tierra se transformaron en una imagen toda del } \\
\text { cielo; Arte de predicar: reglas que instruyeron el modo de } \\
\text { exponer los textos de la Santa Escritura; y todo lo demás } \\
\text { concerniente a la oratoria del pulpito y Vida del venerable } \\
\text { indio Juan Diego en verso castellano. }\end{array}$ & $\begin{array}{l}\text { *Puebla de los Ángeles, 27-X- } \\
\text { 1716-†México, 28-XI-1771. }\end{array}$ \\
\hline $\begin{array}{l}\text { ARENAS, Manuel. } \\
\text { MEX. Fue hermano } \\
\text { de Pedro Arenas. }\end{array}$ & $\begin{array}{l}\text { Poeta. En } 1767 \text { estaba en el colegio } \\
\text { de San Pedro y San Pablo de } \\
\text { México terminando la teología. } \\
\text { Residió en Bolonia y luego en } \\
\text { Ferrara "donde ocupó los últimos }\end{array}$ & $\begin{array}{l}\text { Jesuita desde el } 15-\mathrm{IV}-1757 \text {. Cuatro votos, } 15 \text {-VIII-1773. Según } \\
\text { F. Sebastián fue "buen latino y un muy lúcido y fácil poeta [...]. } \\
\text { Estudiaba de continuo, y ocupaba mucho ratos de la insufrible } \\
\text { ociosidad de Italia en hacer composiciones poéticas, } \\
\text { traduciendo algunos excelentes y píos autores italianos, las que }\end{array}$ & $\begin{array}{l}\text { * Santa Fe y Real de Minas de } \\
\text { Guanajuato, 1-IV-1740- } \\
\text { †Ferrara, 4-IX-1793. }\end{array}$ \\
\hline
\end{tabular}

\footnotetext{
${ }^{80}$ Sebastián, 1767-1796, vol. II: 118.

${ }^{81}$ Alva Rodríguez, 2011: 283-314.

${ }^{82}$ Quiñones Melgoza, 2005: 377-378.

${ }^{83}$ Sebastián, 1767-1796, vol. I: 187-189.
} 


\begin{tabular}{|c|c|c|c|}
\hline & $\begin{array}{l}\text { diez años de su vida". Según F. } \\
\text { Sebastián, "fue de una fantasía muy } \\
\text { viva, la que agitada con los muchos } \\
\text { pesares hizo que pareciera } \\
\text { continuado martirio los } 20 \text { años } \\
\text { últimos de su vida". }\end{array}$ & $\begin{array}{l}\text { leídas por los nuestros, le servían de pasatiempo, y todos } \\
\text { unánimes alababan de excelentes las dichas composiciones. } \\
\text { Ocupado de este modo gozoso y placentero en su destierro se } \\
\text { hallaba cuando recibió el inopinado golpe de la supresión de su } \\
\text { amada madre la Compañía de Jesús [1773]; por varios días no } \\
\text { hizo más que llorar, y después quedó como enajenado de sí, y } \\
\text { no volvió a hallar consuelo en cosa alguna. Su viva fantasía lo } \\
\text { molestó de continuo, y pasó lo restante de su vida como } \\
\text { atolondrado sin saberse gobernar en cosa alguna, ni tener reposo } \\
\text { en ningún lugar [...]”84. }\end{array}$ & \\
\hline $\begin{array}{l}\text { ARAOZ, Juan Manuel } \\
\text { de. CAST. y MEX. }\end{array}$ & $\begin{array}{l}\text { Misionero, operario y humanista, } \\
\text { poeta y escritor. En } 1767 \text { era } \\
\text { prefecto de estudios mayores en el } \\
\text { colegio de La Habana. Residió en } \\
\text { Bolonia, "sirviendo de consuelo a } \\
\text { todos. Acaecida la supresión } \\
\text { [1773], siguió en la misma ciudad } \\
\text { por algún tiempo, mas, temeroso de } \\
\text { los rigurosos fríos de estas partes, } \\
\text { se pasó a Massa Carrara, y de allí a } \\
\text { Génova" } 85 \text {. }\end{array}$ & $\begin{array}{l}\text { Debía ser buen psicólogo, pues se dedicó a mediar en } \\
\text { situaciones especialmente conflictivas ("componer los } \\
\text { disturbios y disensiones en las familias"). Jesuita desde 30-IX- } \\
\text { 1721. Profeso de cuatro votos [el } 15 \text { de agosto de 1739]. Fue } \\
\text { maestro de filosofía y luego de teología en los colegios de } \\
\text { Oaxaca, Guadalajara y San Ildefonso de la Puebla de los } \\
\text { Ángeles, y cierto tiempo operario en el Colegio Máximo de } \\
\text { México. Publicó en } 1763 \text { una Defensa del honor de la } \\
\text { Compañia contra sus calumniadores. Además un "Certamen } \\
\text { Poético para celebrar el Nacimiento del Niño Jesús el año de } \\
\text { 1732, bajo el tema de Lágrimas". En la Biblioteca de la } \\
\text { Universidad de Méjico }{ }^{86} \text {. }\end{array}$ & $\begin{array}{l}\text { *Oñate (Guipúzcoa), 30.IV- } \\
\text { 1704-†Génova, 17.III.1784. }\end{array}$ \\
\hline $\begin{array}{l}\text { BARCO GONZÁLEZ, } \\
\text { Miguel del. CAS. y } \\
\text { MEX. Importante. }\end{array}$ & $\begin{array}{l}\text { Misionero, antropólogo e } \\
\text { historiador. En } 1767 \text { era misionero } \\
\text { en California. Residió en Bolonia, } \\
\text { donde instruyó a los jesuitas de } \\
\text { tercera probación }{ }^{87} \text {. }\end{array}$ & $\begin{array}{l}\text { Jesuita desde 18-V-1728 (Villagarcía de Campos, Valladolid). } \\
\text { Sacerdote de cuarto voto, 15-VIII-1747. Colaborador del } \\
\text { Catálogo de las Lenguas de Hervás a instancias de Clavigero y } \\
\text { de Pedro Cantón (se conserva correspondencia). No aparece en } \\
\text { la BJE, quizá por ruego del mismo Miguel del Barco. } \\
\text { Permaneció } 30 \text { años en California, donde aprendió varias } \\
\text { lenguas indígenas. Es notable su Historia natural y crónica de } \\
\text { la antigua California. }\end{array}$ & $\begin{array}{l}\text { * Casas de Millán (Cáceres, } \\
\text { Extremadura, España), } \\
\text { 13-XI-1706- †Bolonia, } \\
24-X-1790 .\end{array}$ \\
\hline
\end{tabular}

\footnotetext{
${ }^{84}$ Ibíd., 1767-1796, vol. II: 162.

${ }^{85}$ Sebastián, 1767-1796, vol. I: 481; Astorgano Abajo, 2009g: 283-284. Zelis lo llama "Juan Antonio", además de otros errores.

${ }^{86}$ Uriarte-Lecina, 1925-1930, vol. I: 252; Beristáin, 11816-1821, vol. I: 86.

${ }^{87}$ Astorgano Abajo, 2009e: 222; Sebastián, 1767-1796, vol. II: 166-175.
}

104 Antonio Astorgano Abajo y Fuensanta Garrido Domené. Panorama esquemático ... 60-120. 


\begin{tabular}{|c|c|c|c|}
\hline $\begin{array}{l}\text { BENJUMEA, Miguel. } \\
\text { MEX. }\end{array}$ & $\begin{array}{l}\text { Teólogo, operario y prefecto de } \\
\text { congregaciones en diversos } \\
\text { colegios. Ministro en el colegio } \\
\text { Máximo de San Pedro y San Pablo. } \\
\text { En } 1767 \text { era prefecto de la } \\
\text { Visitación y confesor en el Colegio } \\
\text { del Espíritu Santo de Puebla. }\end{array}$ & $\begin{array}{l}\text { Jesuita desde el 4-IV-1733. Cuarto voto, el 15-VIII-1748. } \\
\text { Catedrático de filosofía y teología en el colegio de Guatemala. } \\
\text { Publicó: Elogio fúnebre del Illmo. Sr. Dr. Fr. Pedro Pardo } \\
\text { Figueroa, primer arzobispo de Guatemala }(1751)^{88} \text {. }\end{array}$ & $\begin{array}{l}\text { *Guadalajara (México), } \\
\text { 27-IX-1712-†La Habana, } \\
\text { 4-XII-1767. }\end{array}$ \\
\hline CAMPO, José. MEX. & $\begin{array}{l}\text { Orador. Sólo sabemos lo que dice } \\
\text { Beristáin. Tal vez no fue expulso. } \\
\text { No aparece en Rafael de Zelis. }\end{array}$ & $\begin{array}{l}\text { Jesuita desde 1751. Maestro de retórica en Querétaro en } 1752 . \\
\text { Publicó: Llanto de las aguas en la muerte de el más caudaloso } \\
\text { Jordán. Debidas honras, que se hicieron al Dr. D. Pedro } \\
\text { Bernardino Primo y Jordán, Alférez Real de la muy noble y leal } \\
\text { ciudad de Santiago de Querétaro (1759). }\end{array}$ & $*$ Zacatecas, $1732-\uparrow \measuredangle ?$ \\
\hline $\begin{array}{l}\text { CAMPOY GAZTELU, } \\
\text { José Rafael. MEX. } \\
\text { Importante. } \\
\text { Biografiado por } \\
\text { Maneiro. }\end{array}$ & $\begin{array}{l}\text { Humanista, latinista y brillante } \\
\text { predicador. Prefecto de } \\
\text { congregación en Veracruz en } 1767 . \\
\text { Residió en Ferrara y en Bolonia (ya } \\
\text { en 1773). Maneiro subrayaba en } \\
\text { Campoy su oposición al status quo, } \\
\text { sus tendencias cartesianas, su } \\
\text { correspondencia epistolar con } \\
\text { Gregorio Mayans y el padre José } \\
\text { Francisco de Isla, y la } \\
\text { incomprensión de muchos de sus } \\
\text { hermanos. La admiración de } \\
\text { Maneiro le llevó incluso a } \\
\text { compararle con el norteamericano } \\
\text { Benjamin Franklin. Félix de } \\
\text { Sebastián resume: "En Ferrara, de } \\
\text { donde pasó a la de Bolonia, todo el } \\
\text { tiempo lo ocupó en estudiar y en } \\
\text { escribir de la geografía de la }\end{array}$ & $\begin{array}{l}\text { Jesuita desde } 26-X I-1741 \text {. Cuarto voto, } 12-X I I-1757 \text {. De familia } \\
\text { acomodada, desde niño fue un gran aficionado a las ciencias } \\
\text { experimentales. Sabemos que realizó estudios geográficos y } \\
\text { cartográficos sobre la América española y fue experto en las } \\
\text { ciencias náuticas. Interesado también en la zoología y la } \\
\text { botánica, recorrió los mercados de pescado de Bolonia y Ferrara } \\
\text { para realizar un estudio comparativo entre los peces descritos } \\
\text { por Plinio y los conocidos en la actualidad. Fue maestro de la } \\
\text { brillante generación de "los constructores de la mexicanidad" } \\
\text { (Clavigero, Diego J. Abad, Francisco Javier Alegre, Rafael } \\
\text { Landívar y Juan Luis Maneiro). Según indica Maneiro trabajó } \\
\text { varios años en un comentario, hoy perdido, de De Natura } \\
\text { Rerum de Plinio (Plinio mexicano, o sea, Historia Natural del } \\
\text { Reino de la Nueva España) y en una Carta geográfica de } \\
\text { América Septentrional, manuscritos que se perdieron durante } \\
\text { su viaje al exilio. Campoy contribuyó a un mejor conocimiento } \\
\text { de México a través de estudios sobre la tierra, flora y fauna. }\end{array}$ & $\begin{array}{l}\text { * Los Álamos (Sonora), } \\
\text { 15-VIII-1723- †Bolonia, } \\
29-X I I-1777 .\end{array}$ \\
\hline
\end{tabular}

\footnotetext{
${ }^{88}$ Sebastián, 1767-1796, vol. I: 55-56.
}

105 Antonio Astorgano Abajo y Fuensanta Garrido Domené. Panorama esquemático ... 60-120. 


\begin{tabular}{|c|c|c|c|}
\hline & $\begin{array}{l}\text { América, en que estaba muy } \\
\text { instruido" } 89 \text {. }\end{array}$ & & \\
\hline $\begin{array}{l}\text { CANTÓN UBIARCO, } \\
\text { Pedro. MEX. Regresó } \\
\text { a España entre } 1798 \text { y } \\
1809 \text {. retornó a } \\
\text { México en } 1809 \text {. } \\
\text { Escribió su elogio } \\
\text { fúnebre el P. Basilio } \\
\text { Arrillaga }^{90} \text {. }\end{array}$ & $\begin{array}{l}\text { Lingüista, restaurador y provincial. } \\
\text { Residente en Roma desde } 1793 \text {, } \\
\text { aproximadamente. Maestro de } \\
\text { gramática (medianos y mayores) en } \\
\text { Oaxaca en } 1767 \text {. Residía en } \\
\text { Bolonia en 1773. Es el único } \\
\text { superviviente de los diecisiete } \\
\text { jesuitas expulsos originarios de } \\
\text { Guadalajara que murió en su patria. }\end{array}$ & $\begin{array}{l}\text { Colaborador de Hervás. Jesuita desde 15-VII-1761 y ordenado } \\
\text { sacerdote el 22-IX-1770. Cuarto voto en México el 15-VIII- } \\
\text { 1816. Regresó a su país (1809) con el P. José Ma Castañiza. } \\
\text { Intervino ante Miguel del Barco para que éste colaborase con } \\
\text { Hervás (Carta de Del Barco en Catálogo de las lenguas, 1800, I, } \\
\text { pp. 346-350). Trabajó mucho un Léxico castellano-francés, que } \\
\text { más tarde destruyó por humildad. Beristaín le atribuye la } \\
\text { traducción del Viacrucis del beato Leonardo a Portu Mauricio } \\
\text { y las Meditaciones para las festividades de algunos Santos }{ }^{91} \text {. }\end{array}$ & $\begin{array}{l}\text { * Guadalajara (Jalisco), } \\
\text { 19-II-1745-†México (D.F.), 16- } \\
\text { X-1833. }\end{array}$ \\
\hline $\begin{array}{l}\text { CARAVANTES, } \\
\text { Gabriel. MEX. }\end{array}$ & $\begin{array}{l}\text { Coadjutor. En } 1767 \text { era sacristán en } \\
\text { el colegio de San Pedro y San Pablo } \\
\text { de México. Vivió en Bolonia, y } \\
\text { después en Castel San Pietro. }\end{array}$ & $\begin{array}{l}\text { Jesuita desde } 31-\mathrm{V}-1737 \text {. Fue muy devoto de Santa Anna, } \\
\text { "imprimiendo y dando novenas y estampas de la santa a todos } \\
\text { para encenderlos en la devoción de tan poderosa protectora" } 92 \text {. }\end{array}$ & $\begin{array}{l}\text { * Valladolid de Michoacán, } 7- \\
\text { IX- } 1718-\dagger \text { Castel San Pietro, } \\
\text { 12-III-1775. }\end{array}$ \\
\hline $\begin{array}{l}\text { CASTAÑIZA } \\
\text { GONZÁLEZ, José } \\
\text { María. MEX. } \\
\text { Regresó a España } \\
\text { entre } 1798 \text { y } 1809 .\end{array}$ & $\begin{array}{l}\text { Provincial y restaurador. Era } \\
\text { estudiante de Teología en el } \\
\text { Colegio Máximo de San Pedro y } \\
\text { San Pablo en } 1767 \text {. Residente en } \\
\text { Bolonia hasta 1793, } \\
\text { aproximadamente, en que se } \\
\text { trasladó a Roma. Trabajó como } \\
\text { sacerdote secular en Roma con } \\
\text { Pedro Cantón. Regresó a México en } \\
1809 \text { con los PP. Cantón y Antonio } \\
\text { Barroso }^{93} \text {. }\end{array}$ & $\begin{array}{l}\text { Jesuita desde 18-III-1761. Profeso de cuarto voto desde 15-VIII- } \\
\text { 1816. Era el hijo mayor del marqués de Castañiza, lo que le } \\
\text { permitió ser sostén de sus compañeros de exilio, gracias a la } \\
\text { cuantiosa fortuna. Restaurada la Compañía por Pío VII ( } 7 \text { agosto } \\
\text { 1814) y publicada la Real Cédula de Fernando VII (10 septiembre } \\
\text { 1815) de restablecimiento en sus reinos por el virrey Félix M. } \\
\text { Calleja (24 febrero 1816), en el Colegio de S. Ildefonso se abrió } \\
\text { (12 julio) el noviciado con ocho candidatos. En Italia tradujo del } \\
\text { italiano El tratado de la beneficencia de Dios, que escribió el } \\
\text { jesuita P. Alejandro Diotalevi. Escribió: Relación del } \\
\text { restablecimiento de la Sagrada Compañia de Jesús en el Reyno } \\
\text { de Nueva España, y de la entrega a sus religiosos del Real } \\
\text { Seminario de San Ildefonso de México (México, 1816), y unas }\end{array}$ & $\begin{array}{l}\text { * Capital de México, } \\
\text { 23-III-1744- †México, } \\
\text { 24-XI-1816. }\end{array}$ \\
\hline
\end{tabular}

\footnotetext{
${ }^{89}$ Ibíd., 1767-1796, vol. I: 306-308.

${ }^{90}$ Decorme, 1914, vol. I: 257-259.

${ }^{91}$ Beristaín, 1816-1821, vol. I: 264.

${ }^{92}$ Sebastián, 1767-1796, vol. I: 253.

${ }^{93}$ Decorme, 1914, vol. I: 32-116.
} 


\begin{tabular}{|c|c|c|c|}
\hline & & Meditaciones sobre los beneficios divinos. & \\
\hline $\begin{array}{l}\text { COLAZO PORTILLO, } \\
\text { Manuel José. MEX. }\end{array}$ & $\begin{array}{l}\text { Moralista e historiador. Confesor y } \\
\text { prefecto de dos congregaciones en } \\
\text { Tepotzotlán en 1767. Residente en } \\
\text { Bolonia en 1773. Según Félix de } \\
\text { Sebastián, en el colegio de San } \\
\text { Andrés de México juntó materiales } \\
\text { para una Historia de la Provincia, } \\
\text { pero "dejó que otro la extendiese [el } \\
\text { padre Francisco Javier Alegre], } \\
\text { ocupándose, como se lo ordenaron, } \\
\text { en escribir varios elogios latinos de } \\
\text { muchos varones ilustres de nuestra } \\
\text { provincia, que fueron mandados a } \\
\text { Roma para la historia general""4. }\end{array}$ & $\begin{array}{l}\text { Jesuita desde 6-VI-1737. Cuarto voto, el 15-VIII-1754. } \\
\text { Publicó: Novena de meditaciones que han de practicarse en } \\
\text { honra de San Felipe Neri, fundador de la Ven. Congregación } \\
\text { del Oratorio. Traducida del idioma italiano al castellano } \\
\text { (México, 1751) y Catalogus Provinciae Mexicanae Societatis } \\
\text { Jesu, in quo singulorum nomen, cognomen, patria, aetas atque } \\
\text { ingressus in eamdem continetur, Mexici, 1748. }\end{array}$ & $\begin{array}{l}\text { * Guadalajara, 22-V-1721- } \\
\text { † Bolonia, 31-VII-1792. }\end{array}$ \\
\hline $\begin{array}{l}\text { CORRO, Antonio. } \\
\text { MEX. Biografiado } \\
\text { por Maneiro. }\end{array}$ & $\begin{array}{l}\text { Orador sagrado. Catedrático de } \\
\text { gramática en el Colegio de San } \\
\text { Ildefonso. Tuvo, en vida, fama de } \\
\text { santo. En sus actividades dedicó } \\
\text { mucho de su tiempo y esfuerzo a } \\
\text { los enfermos y a los pobres. En } \\
1767 \text { era capellán de una hacienda } \\
\text { del Colegio de San Andrés de } \\
\text { México. Félix de Sebastián } \\
\text { biografía al "angelical P. Antonio } \\
\text { Corro", sin aludir a sus escritos }\end{array}$ & $\begin{array}{l}\text { Jesuita desde 13-IV-1743. Cuatro votos el 15-VIII-1758. } \\
\text { Enseñó letras humanas y filosofía en Durango. Prefecto de la } \\
\text { Congregación de Buenamuerte. Escribió: Oración fúnebre en } \\
\text { las exequias de los militares españoles difuntos, celebradas en } \\
\text { la iglesia de la Casa Profesa de México, México, } 1765 \text {. } \\
\text { También dejó unas «Consultas morales» y «Sermones y } \\
\text { artículos piadosos diversos». }\end{array}$ & $\begin{array}{l}\text { * Córdoba (Puebla de los } \\
\text { Ángeles, México), 10-I-1724- } \\
\text { †Veracruz, } 13 \text { (12, según Zelis)- } \\
\text { XI-1767. }\end{array}$ \\
\hline $\begin{array}{l}\text { CHAVES, Juan de. } \\
\text { ANDALUCÍA y MEX. }\end{array}$ & $\begin{array}{l}\text { En } 1767 \text { enseñaba retórica en el } \\
\text { Colegio del Espíritu Santo de la } \\
\text { Puebla. Residió en Ferrara, salvo un } \\
\text { año que estuvo en Faenza, "por }\end{array}$ & $\begin{array}{l}\text { Jesuita desde } 4 \text {-II-1754. Cuatro votos, el 15-VIII-1771. Pasó a } \\
\text { la Provincia de Nueva España en la misión del año 1760. Según } \\
\text { F. Sebastián fue "singularmente devoto de San Juan } \\
\text { Nepomuceno, cuya devoción promovía en todos, para lo que }\end{array}$ & $\begin{array}{l}\text { *Sevilla, 27-VII-1738-†Bolonia } \\
7 \text { (8, según Zelis)-XI-1780. }\end{array}$ \\
\hline
\end{tabular}

\footnotetext{
94 Sebastián, 1767-1796, vol. II: 220.
}

${ }^{95}$ Ibíd., 1767-1796, vol. I: 37-39. No confundir con su hermano el coadjutor Alfonso Corro, fallecido también en Varcruz, dos días después que Antonio, el 15 de noviembre, según Sebastián, 1767-1796, vol. I: 42-43. 


\begin{tabular}{|c|c|c|c|}
\hline & $\begin{array}{l}\text { recobrar su perdida salud", y } \\
\text { después de } 1773 \text { en Bolonia. }\end{array}$ & $\begin{array}{l}\text { tradujo de español en italiano varias oraciones en honor del } \\
\text { santo, que dio a la imprenta" } 96 \text {. }\end{array}$ & \\
\hline $\begin{array}{l}\text { DÁVILA MANZANO, } \\
\text { Salvador. MEX. } \\
\text { Biografiado por } \\
\text { Maneiro. }\end{array}$ & $\begin{array}{l}\text { Latinista, poeta y orador. En } 1767 \\
\text { era rector del Seminario de San } \\
\text { Ignacio de Puebla. Residente en } \\
\text { Bolonia en } 1773 \text {. En Bolonia fue } \\
\text { maestro de Pedro José Márquez. } \\
\text { Parece que no escribió nada en el } \\
\text { destierro, donde "se empleó } \\
\text { siempre en estudiar y ser santo" } 97 .\end{array}$ & $\begin{array}{l}\text { Jesuita desde 19-VI-1745. Cuarto voto, el 15-VIII-1763. Buen } \\
\text { latinista, inclinado a la física y las matemáticas, trabajó por } \\
\text { propagar entre los jóvenes el gusto por la literatura. Publicó: } \\
\text { Oración fúnebre de los militares españoles difuntos, dicha en la } \\
\text { iglesia de la Casa Profesa de México, año de } 1765 \text { (México, } \\
\text { 1766). Se ha perdido una obra titulada Vidas de algunos sujetos } \\
\text { más ilustres de la Provincia de Nueva España muertos en el } \\
\text { destierro de Italia }\end{array}$ & $\begin{array}{l}\text { *Guadalajara de México, } \\
\text { 15-III-1727-†Bolonia, } \\
\text { 11-I-1781. }\end{array}$ \\
\hline $\begin{array}{l}\text { ESPARZA SEGURA, } \\
\text { Domingo. Regresó a } \\
\text { España entre } 1798 \text { y } \\
1801 .\end{array}$ & $\begin{array}{l}\text { Cronista. En } 1767 \text { era maestro de } \\
\text { Filosofía en Oaxaca. Residió en } \\
\text { Bolonia, donde continuaba en } 1796 \text {, } \\
\text { según el P. Luengo. En septiembre } \\
\text { de } 1801 \text { estaba en Civitavecchia }{ }^{99} \text {. }\end{array}$ & $\begin{array}{l}\text { Jesuita desde } 2-X-1754 \text { en la Provincia de Aragón. Cuarto voto, } \\
\text { el } 2 \text {-II-1770. Pasó a México en } 1755 \text {. Decorme le atribuye un } \\
\text { Breve relato de la expulsión del Colegio de Puebla }{ }^{100} \text {. }\end{array}$ & $\begin{array}{l}* \text { Onteniente (Valencia), } 18-\text { II- } \\
1732-\uparrow \text { Civitavecchia, } 18-\text { IX- } \\
1805 .\end{array}$ \\
\hline $\begin{array}{l}\text { ESTRADA, José de. } \\
\text { MEX. }\end{array}$ & $\begin{array}{l}\text { Teólogo. Según F. Sebastián, } \\
\text { "Gozaba poca salud y se hallaba de } \\
\text { convaleciente en el colegio de San } \\
\text { Javier de Puebla cuando fue } \\
\text { arrestado [1767], y conducido con } \\
\text { todos hasta el pueblo de Jalapa. } \\
\text { Aquí, considerando los comisarios } \\
\text { reales que el remitirlo al Puerto de } \\
\text { Veracruz era mandarlo a morir, } \\
\text { tomaron el expediente de volverlo a }\end{array}$ & $\begin{array}{l}\text { Jesuita desde el 28-II-1737. Cuatro votos, el 15-VIII-1754. Leyó } \\
\text { dos veces curso de filosofía, uno en Oaxaca y otro en México. } \\
\text { Fue maestro de teología y también vicerrector del colegio de } \\
\text { Guadalajara: "Promovía siempre y en todas ocasiones la } \\
\text { devoción a la gran Madre de Dios, y en todas partes procuraba } \\
\text { fuera venerado nuestro padre San Ignacio, ya con la pluma, ya } \\
\text { con sus delicados y elocuentes panegíricos, [...]. En el poco } \\
\text { tiempo que vivió en Guadalajara dedicó un bellísimo altar a } \\
\text { nuestro padre San Ignacio, en que se ven juntas la devoción y el } \\
\text { buen gusto. [...] Aquí [estando prisionero] se ocupó como un }\end{array}$ & $\begin{array}{l}\text { * Ciudad de México, } 31-V- \\
\text { 1721-†Puebla de los Ángeles, } \\
\text { 19-II-1778. }\end{array}$ \\
\hline
\end{tabular}

\footnotetext{
${ }^{96}$ Ibíd., 1767-1796, vol. I: 383.

${ }^{97}$ Sebastián, 1767-1796, vol. I: 388 .

${ }^{98}$ Uriarte-Lecina, 1925-1930, vol. II: 342-343.

${ }^{99}$ Según una carta, fechada en Colorno el 1 de septiembre de 1801, de José Pignatelli a Domingo Esparza, residente en Civitavecchia (Italia), el susodicho Esparza, antiguo compañero de noviciado de José Pignatelli, en Tarragona (España), deseaba incorporarse al noviciado de Colorno (http://www.sjweb.info/news/index. Consulta, 4-enero-2014).

${ }^{100}$ Decorme, 1941.
}

108 Antonio Astorgano Abajo y Fuensanta Garrido Domené. Panorama esquemático ... 60-120. 


\begin{tabular}{|c|c|c|c|}
\hline & $\begin{array}{l}\text { la ciudad de la Puebla, donde vivió } \\
\text { prisionero más de } 10 \text { años". }\end{array}$ & $\begin{array}{l}\text { otro San Pablo en consolar a todos con sus santas cartas, ya que } \\
\text { no podía a boca" } 101 \text {. }\end{array}$ & \\
\hline $\begin{array}{l}\text { FERNÁNDEZ, Eligio. } \\
\text { MEX. }\end{array}$ & $\begin{array}{l}\text { Erudito. En } 1767 \text { era estudiante en } \\
\text { el Colegio del Espíritu Santo de } \\
\text { Puebla. Residente en Bolonia en } \\
\text { 1773; en Roma en } 1793 \text {. Estuvo en } \\
\text { el acto de restablecimiento de la } \\
\text { Compañía en agosto de } 1814 \text {, pero } \\
\text { no regresó a México, por sus } \\
\text { achaques. }\end{array}$ & $\begin{array}{l}\text { Jesuita desde 6-XII-1757. Aunque no hemos encontrado } \\
\text { ninguna obra literaria suya, la correspondencia conservada y su } \\
\text { interés por guardar los escritos de Blas Miner (nº } 359) \text { nos } \\
\text { inclinan a presumirla: "En poder del señor abate D. Elijio } \\
\text { Fernández, he visto y observado los manuscritos siguientes, de } \\
\text { letra del señor Miner", comenta Hervás (BJE, p. 635). Su } \\
\text { correspondencia en: Lettere scritte al P. Eligio Antonio } \\
\text { Fernández S.J. da suoi amici e parenti dal Messico, Archivo } \\
\text { Sociedad de Jesús, Roma (ARSJ), Vitae 1006, s/f. }\end{array}$ & $\begin{array}{l}\text { *Puebla, 7-VI-1740- } \uparrow \text { Roma, } 30- \\
\text { XII-1818. }\end{array}$ \\
\hline $\begin{array}{l}\text { GÁNDARA PÁEZ DE } \\
\text { GUZMÁN, Salvador } \\
\text { Cayetano de la. } \\
\text { MEX. }\end{array}$ & $\begin{array}{l}\text { Biógrafo y Provincial. En } 1767 \text { era } \\
\text { Provincial (Casa Profesa de } \\
\text { México), en sustitución de } \\
\text { Francisco Ceballos desde el año } \\
\text { anterior. Residió en Bolonia, donde } \\
\text { reunió a los estudiantes en un } \\
\text { palacio, donde siguieron sus } \\
\text { estudios y eran ordenados } \\
\text { sacerdotes. Ampliamente reseñado } \\
\text { por Félix de Sebastián, pero sin } \\
\text { mencionar ningún escrito } \\
\text { me2 }^{\text {. }}\end{array}$ & $\begin{array}{l}\text { Jesuita desde 20-IV-1726. Cuarto voto, el 10-X-1744. Maestro } \\
\text { de Gramática en Ciudad Real; maestro de Filosofía y Teología } \\
\text { en Guatemala; rector en Guatemala, Oaxaca, Querétaro y la } \\
\text { ciudad de México. Publicó: 1. Carta que sobre la vida y muerte } \\
\text { del Padre Doctor Francisco Xavier Lazcano, dirige a los } \\
\text { Padres de la Compañía de Jesús de la Provincia de México el } \\
\text { P..., México, en el Real y más antiguo Colegio de S. Ildefonso, } \\
\text { 1763. 2. Vida del Padre Miguel Venegas, jesuita mexicano, } \\
\text { México, } 1765 .\end{array}$ & $\begin{array}{l}\text { *Real de Minas de San } \\
\text { Sebastián (Nueva Vizcaya, } \\
\text { México), 28-VIII 1709- } \\
\text { †Bolonia, 23-XI-1773. }\end{array}$ \\
\hline $\begin{array}{l}\text { LEGUINAZÁBAL, } \\
\text { Joaquín. MEX. }\end{array}$ & $\begin{array}{l}\text { Polígrafo. Poeta. En } 1767 \text { era } \\
\text { prefecto de la congregación de } \\
\text { Dolores y confesor en el colegio de } \\
\text { León en Michoacán. Residió en } \\
\text { Bolonia. "Todo el tiempo que } \\
\text { estuvo en este su destierro y retiro } \\
\text { de Bolonia, no se supo qué es lo } \\
\text { que hacía, cómo se trataba y en qué } \\
\text { ocupaba el tiempo, pues fuera que } \\
\text { en el andar a decir misa, que era en }\end{array}$ & $\begin{array}{l}\text { Jesuita desde el } 17 \text { ( } 7 \text { según Zelis)-XII-1744. Cuatro votos, el } \\
15 \text {-VIII-1763. "Estudió humanidad, y se aprovechó tanto en esta } \\
\text { ciencia cuanto lo dio a conocer en sus muchas composiciones } \\
\text { lo restante de su vida. [...] regentó la clase de retórica en el } \\
\text { Colegio Máximo de México, donde dio a conocer a todos que } \\
\text { era grande orador, gran latino y gran poeta. [...] Son también } \\
\text { varios los escritos sobre materias muy delicadas de la sagrada } \\
\text { teología escolástica, moral y dogmática, hechos para impugnar a } \\
\text { varios autores coetáneos en que muestra su profunda erudición y } \\
\text { gran ciencia, y una muy notable ingenuidad, sin zaherir en nada }\end{array}$ & $\begin{array}{l}\text { * Veracruz, } 29 \text { (27, según } \\
\text { Zelis)-I-1729- †Bolonia, 21-IX- } \\
1795 .\end{array}$ \\
\hline
\end{tabular}

${ }^{101}$ Sebastián, 1767-1796, vol. I: 313.

${ }^{102}$ Ibíd., 1767-1796, vol. I: 232.

109 Antonio Astorgano Abajo y Fuensanta Garrido Domené. Panorama esquemático ... 60-120. 


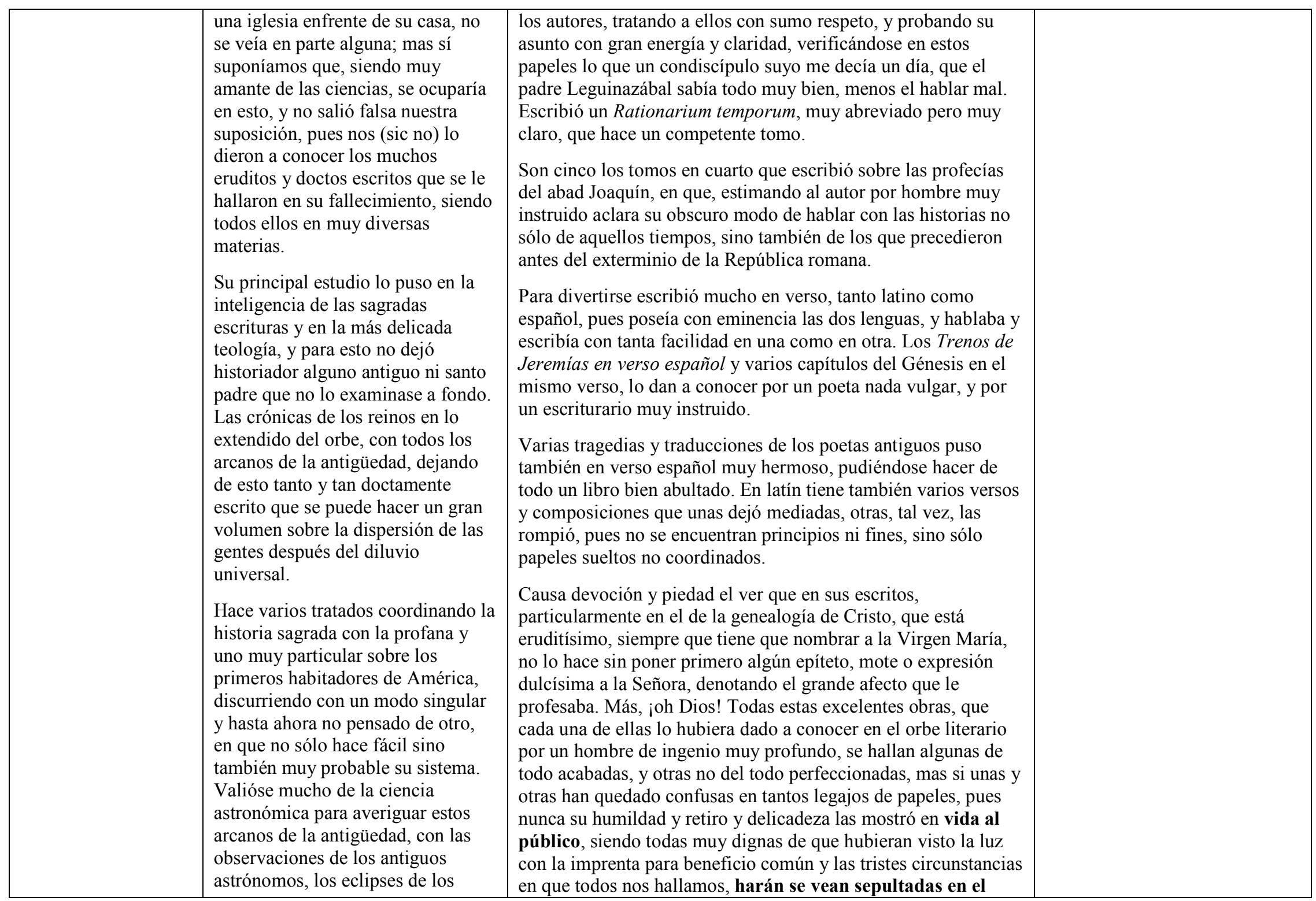

110 Antonio Astorgano Abajo y Fuensanta Garrido Domené. Panorama esquemático ... 60-120. 


\begin{tabular}{|c|c|c|c|}
\hline & $\begin{array}{l}\text { tiempos pasados y los demás } \\
\text { fenómenos que dejaron en sus } \\
\text { memorias. Para conseguir este ramo } \\
\text { de ciencia matemática, estudió y da } \\
\text { a conocer [que] sabía muy bien } \\
\text { todos los fundamentos en que ésta } \\
\text { estriba y la grande enumeración } \\
\text { algebraica; y así se le encontraron } \\
\text { muchos escritos sobre esto". }\end{array}$ & olvido" 103 . & \\
\hline $\begin{array}{l}\text { LIÉBANA, José. } \\
\text { ANDALUCÍA Y } \\
\text { MEX. }\end{array}$ & $\begin{array}{l}\text { Poeta. En } 1767 \text { era misionero en la } \\
\text { Provincia de Sonora (misión de } \\
\text { Bacca de Guachi. }\end{array}$ & $\begin{array}{l}\text { Jesuita desde 3-IV-1755. Sacerdote escolar. Según Sebastián } \\
\text { "fue hombre muy dado a los ministerios, muy circunspecto, y al } \\
\text { mismo tiempo muy afable. Gozaba gran facilidad en la poesía } \\
\text { castellana, la que tomaba por modo de entretenimiento, } \\
\text { trabajando siempre en cosas espirituales y devotas. Se enfermó } \\
\text { en el viaje, y se rindió de todo punto sin poderse mover en el } \\
\text { pueblo de Istlan, donde murieron varios compañeros suyos"104. }\end{array}$ & $\begin{array}{l}\text { * Grazalema (Málaga), 21-XI- } \\
\text { 1737- †Istlan (México), 7-X- } \\
1768\end{array}$ \\
\hline $\begin{array}{l}\text { LÓPEZ DE PRIEGO, } \\
\text { Antonio María. } \\
\text { MEX. }\end{array}$ & $\begin{array}{l}\text { Cronista de la expulsión. Residió en } \\
\text { Bolonia. En } 1767 \text { era consultor de } \\
\text { casa, catequista y maestro de } \\
\text { idioma mexicano en el colegio de } \\
\text { San Javier de Puebla. }\end{array}$ & $\begin{array}{l}\text { Jesuita desde 3-IV-1751. Cuarto voto, el 15-VIII-1766. López } \\
\text { de Priego es un notable cronista de la expulsión, que Hervás no } \\
\text { incluye en su BJE, probablemente por ser materia prohibida por } \\
\text { la Pragmática Sanción de abril de } 1767 \text {. Título de su crónica: } \\
\text { Carta de un religioso de los extintos jesuitas, a una hermana } \\
\text { suya, religiosa del convento de Santa Catarina de la Puebla de } \\
\text { los Ángeles, escrita en la ciudad de Bolonia en } 1^{\circ} \text { de octubre de } \\
1785 \text {. Trata de lo acaecido a estos religiosos desde el día de su } \\
\text { arresto hasta esta fecha, con varias noticias de la Italia y } \\
\text { ciudad de Roma. Publicado por Mariano Cuevas }{ }^{105} \text {. }\end{array}$ & $\begin{array}{l}* \text { Puebla, 8-II-1730- } † \text { Bolonia, } \\
\text { 22-I- } 1802 .\end{array}$ \\
\hline $\begin{array}{l}\text { MACIDA, Pedro } \\
\text { Pablo. ITALIA y } \\
\text { MEX. }\end{array}$ & $\begin{array}{l}\text { Misionero en Chinipas (Gusarapes). } \\
\text { Quedó enfermo n Tula (Nueva } \\
\text { España) }\end{array}$ & $\begin{array}{l}\text { Jesuita desde el 13-XII-1731. Cuarto voto, el 16-VI-1740. } \\
\text { Según Félix de Sebastián, "fue muy aplicado a los ministerios y } \\
\text { civilizó mucho aquellos naturales, cuya lengua poseía, y la }\end{array}$ & $\begin{array}{l}\text { * Cerdeña, 25-I-1703-†Puerto } \\
\text { de Santa María (según Félix de } \\
\text { Sebastián; Puebla, según Zelis), }\end{array}$ \\
\hline
\end{tabular}

${ }^{103}$ Ibíd., 1767-1796, vol. II: 324-327.
${ }^{104}$ Ibíd., 1767-1796, vol. I: 117.

${ }^{105}$ Cuevas, 1944: 15-177.

111 Antonio Astorgano Abajo y Fuensanta Garrido Domené. Panorama esquemático ... 60-120. 


\begin{tabular}{|c|c|c|c|}
\hline & & $\begin{array}{l}\text { hablaba admirablemente, habiendo escrito muchas prédicas e } \\
\text { instrucciones de doctrinas, para el alivio de los misioneros"106. }\end{array}$ & 30-VIII-1768. \\
\hline $\begin{array}{l}\text { MIDDENDORF } \\
\text { RODENBORG, Bernar- } \\
\text { do. ALEM. y MEX. }\end{array}$ & $\begin{array}{l}\text { Misionero en Sonora (Movas), } \\
\text { donde estaba en 1767, y cronista de } \\
\text { la expulsión. Prisionero de Carlos } \\
\text { III hasta } 1776 .\end{array}$ & $\begin{array}{l}\text { Jesuita desde el 21-X-1741. Cuarto voto, el 31-VII-1760. Llegó } \\
\text { a México en 1756. Escribió un diario sobre la expulsión, } \\
\text { Vertreibung und Cefangenschaft, publicado en } 1845 \text { en el } \\
\text { "Katholischen Magazin für Wisenschaft und Leben""107. }\end{array}$ & $\begin{array}{l}\text { * Westfalia, 14-II-1723- } \\
\text { †Alemania, después de } 1776 .\end{array}$ \\
\hline $\begin{array}{l}\text { MIRANDA, Juan } \\
\text { Francisco. MEX. }\end{array}$ & $\begin{array}{l}\text { Lingüista y moralista. En } 1767 \text { era } \\
\text { confesor en el Colegio de San Luis } \\
\text { de la Paz. Residió en Bolonia, } \\
\text { donde falleció a los } 67 \text { años. } \\
\text { Enterrado en la parroquia de San } \\
\text { Próculo de Bolonia (Libro XIV.3). }\end{array}$ & $\begin{array}{l}\text { Entró en la Compañía el 24-III-1740, según el catálogo de la } \\
\text { Provincia de 1755, año en que era operario de indios, sacerdote } \\
\text { escolar y superior del Seminario de San Martín en Tepozotlán. } \\
\text { Cuarto voto, el 15-VIII-1757. Vice-rector del Colegio de San } \\
\text { Luis de la Paz (1764). Publicó: Catecismo breve en lengua } \\
\text { otomí (México, 1759), para cumplir una promesa a la Virgen de } \\
\text { Loreto, "que milagrosamente lo salvó", según puntualiza Félix } \\
\text { de Sebastián }{ }^{108} \text {. }\end{array}$ & $\begin{array}{l}\text { *Tlacomulco, 20-VI-1720- } \\
\text { †Bolonia, 9-V-1787. }\end{array}$ \\
\hline $\begin{array}{l}\text { NAVA, Juan Antonio. } \\
\text { MEX. }\end{array}$ & $\begin{array}{l}\text { Biógrafo. En } 1767 \text { era operario en } \\
\text { el Colegio de San Ildefonso de } \\
\text { Puebla de los Ángeles, esperando } \\
\text { nueva asignación. }\end{array}$ & $\begin{array}{l}\text { Jesuita desde 29-II-1744. Cuarto voto, el 15-VIII-1763. Rector y } \\
\text { maestro de Teología en Pátzcuaro. Rector en Puebla. Con sus } \\
\text { manuscritos publicó el P. Perelli la Vida de la venerable } \\
\text { Catalina Boseti, primera obra impresa con nombre de jesuita } \\
\text { tras el restablecimiento de la Compañía. }\end{array}$ & $\begin{array}{l}\text { * Puebla, 22-VIII-1726- } \\
\dagger \text { Roma, 19-VI-1815. }\end{array}$ \\
\hline $\begin{array}{l}\text { NORIEGA MIOÑO, } \\
\text { Juan de Dios. MEX. } \\
\text { Su hermano Antonio } \\
\text { también fue jesuita. }\end{array}$ & $\begin{array}{l}\text { Latinista. En } 1767 \text { era maestro de } \\
\text { filosofía en Zacatecas. Residió en } \\
\text { Castel San Pedro, en Bolonia, Fano, } \\
\text { Rímini y en Sestri }\end{array}$ & $\begin{array}{l}\text { Jesuita desde } 25-\mathrm{II}-1752 \text {. Cuarto voto, el 26-II-1769. Según F. } \\
\text { Sebastián, era "un gran latino, tanto en prosa como en todo } \\
\text { género de verso", aunque desconocemos el alcance de su } \\
\text { producción literaria, debido a su personalidad desequilibrada } \\
\text { ("fue sujeto predominado mucho de la cólera") }{ }^{109} \text {. }\end{array}$ & $\begin{array}{l}\text { * San Juan de Villahermosa } \\
\text { (Tabasco), 12-IV-1739-†Sestri, } \\
\text { 31-VIII-1784. }\end{array}$ \\
\hline $\begin{array}{l}\text { ORTEGA, Miguel José } \\
\text { de. MEX. No fue }\end{array}$ & Moralista. & $\begin{array}{l}\text { Jesuita desde } 1702 \text {. Luego de ordenarse pasó a Guatemala a } \\
\text { enseñar artes, y enseguida a Oaxaca, donde leyó teología hasta } \\
\text { 1742, en que fue destinado al Colegio del Espíritu Santo de }\end{array}$ & *Tlaxcala, $1784-\dagger 1762$. \\
\hline
\end{tabular}

$\overline{106}$ Sebastián, 1767-1796, vol. I: 93-94.

${ }^{107}$ Decorme, 1941, vol. I: 477-478.

${ }^{108}$ Sebastián, 1767-1796, vol. II: 70.

${ }^{109}$ Ibíd., 1767-1796, vol. I: 491-494.

112 Antonio Astorgano Abajo y Fuensanta Garrido Domené. Panorama esquemático ... 60-120. 


\begin{tabular}{|c|c|c|c|}
\hline expulso. & & $\begin{array}{l}\text { Puebla, a enseñar en el templo de la Compañía la doctrina } \\
\text { cristiana. Publicó: Los dos amantes del corazón, Loyola y } \\
\text { Nolasco. Sermón panegyrico que en la fiesta de N. P. S. Pedro } \\
\text { Nolasco, que se hizo en el Convento de Nuestra Señora de la } \\
\text { Merced, en la Ciudad de Zacatecas, el día } 31 \text { de enero de este } \\
\text { año de 1734, predicó el R. P..., México, } 1734 \text {. }\end{array}$ & \\
\hline $\begin{array}{l}\text { PFEFFERKORN } \\
\text { ESCHENBRENDER, } \\
\text { Ignacio. ALEM. y } \\
\text { MEX. }\end{array}$ & $\begin{array}{l}\text { Misionero en Sonora desde } 1754 . \\
\text { En } 1767 \text { estaba en la misión de } \\
\text { Cucurupe. Fue prisionero y rehén } \\
\text { de Carlos III desde } 1769 \text { hasta el } 10 \\
\text { de junio de } 1778, \text { en que regresó a } \\
\text { su patria. }\end{array}$ & $\begin{array}{l}\text { Jesuita desde 22-X-1742. Cuatro voto, el 29-VI-1760. En su } \\
\text { patria y después de } 1778 \text { escribió algunas obras literarias, } \\
\text { destacando Beschreibung der Landschaft Sonora samt anderen } \\
\text { merkwürdigen Nachrichten van den inneren Theilen Neu- } \\
\text { Spaniens und Reise aus Amerika bis in Deutschland, } 2 \text { vols., } \\
\text { Colonia, Langensche Buchhandlung, } 1794-1795^{110} \text {. }\end{array}$ & $\begin{array}{l}\text { *Mannheim (Palatinado, } \\
\text { Alemania), 31-VII-1725- } \dagger \\
\text { Siegburg, 16-VI-1798. }\end{array}$ \\
\hline $\begin{array}{l}\text { REALES, Pedro. } \\
\text { MEX. } \\
\text { Biografiado por } \\
\text { Maneiro. }\end{array}$ & $\begin{array}{l}\text { Moralista. Provincial hasta mayo de } \\
1763 \text {. En } 1767 \text { era rector del } \\
\text { colegio Máximo de México y } \\
\text { consultor de la Provincia. } \\
\text { Expatriado, murió en Veracruz }{ }^{111} \text {. }\end{array}$ & $\begin{array}{l}\text { Jesuita desde 18-IV-1722. Cuarto voto, el 15-VIII-1739. } \\
\text { Catedrático de filosofía en el Colegio Máximo, donde fueron } \\
\text { sus disć́pulos los PP. Diego J. Abad y Campoy. En el Colegio } \\
\text { de Guadalajara enseñó teología. Gobernó los colegios de San } \\
\text { Gerónimo de Puebla de San Juan, el de Tepozotlán y el } \\
\text { Máximo; prepósito de la Casa Profesa y secretario de la } \\
\text { Provincia. Amplió el Colegio de Guadalajara. Reedificó el } \\
\text { Colegio de S. Pedro y S. Pablo. En la biblioteca del Colegio de } \\
\text { S. Gregorio de México vio Beristáin dos de sus obras: } 1 \text {. El } \\
\text { novelo religioso o, vida de los religiosos nuevos, obra escrita en } \\
\text { latín por el Ven. P. Gaspar Druzbiki y traducida al castellano y } \\
\text { Ejercicio para novicios religiosos, distribuidos en los doce } \\
\text { meses del año. } 2 \text { Otra obra es: Carta del Padre rector Pedro } \\
\text { Reales, en que da noticia a los superiores de esta Provincia de } \\
\text { Nueva España de la Compañía de Jesús, de la muerte y } \\
\text { exemplares virtudes del H. Vicente González, novicio estudiante } \\
\text { de la misma Compañia en el colegio de Tepozotlán, } 3 \text { de } \\
\text { septiembre de } 1754 \text {. }\end{array}$ & $\begin{array}{l}\text { * Abula, Fuente de Sol, 23-IV- } \\
1704-\uparrow \text { Veracruz, 23-VIII-1767. }\end{array}$ \\
\hline REINOSO SANCHO, & $\begin{array}{l}\text { Moralista. En } 1767 \text { estaba de } \\
\text { capellán en el Colegio Máximo de }\end{array}$ & $\begin{array}{l}\text { Jesuita desde 19-IV-1736. Cuarto voto el 15-VIII-1750. } \\
\text { Publicó: La injusticia por derecho, justificada por gracia: }\end{array}$ & $\begin{array}{l}\text { *Santa María de los Lagos, } 15- \\
\text { VIII-1713-†Bolonia, 10-X- }\end{array}$ \\
\hline
\end{tabular}

${ }^{110}$ Decorme, 1941, vol. I: 505.

${ }^{111}$ Sebastián, 1767-1796, vol. I: 13-15.

113 Antonio Astorgano Abajo y Fuensanta Garrido Domené. Panorama esquemático ... 60-120. 


\begin{tabular}{|c|c|c|c|}
\hline Jacinto. MEX. & $\begin{array}{l}\text { San Pedro y San Pablo de México. } \\
\text { Enterrado en la Iglesia de San } \\
\text { Martín de Bolonia. Félix de } \\
\text { Sebastián omite sus obras («en casa } \\
\text { lo pasaba estudiando, orando y } \\
\text { consolando a los que lo iban a } \\
\text { visitar») }^{112} \text {. }\end{array}$ & $\begin{array}{l}\text { sermón que predicó el P... en el Colegio de S. Luis de la Paz, } \\
\text { día tercero del festejo con que se aplaudió, confirmada Patrona } \\
\text { con oficio y missa, la Virgen María, en su milagrosa Imagen de } \\
\text { Guadalupe. Dedícalo a la misma Sacratíssima Señora e Imagen } \\
\text { Milagrosa, México, } 1759 .\end{array}$ & 1792. \\
\hline $\begin{array}{l}\text { RESTÁN GAVIÑO, } \\
\text { José Nepomuceno. } \\
\text { MEX. }\end{array}$ & $\begin{array}{l}\text { Moralista. En } 1767 \text { estaba de } \\
\text { doctrinero en la Casa Profesa de } \\
\text { México. Enterrado en la Iglesia de } \\
\text { Santa María de la Caridad de } \\
\text { Bolonia. }\end{array}$ & $\begin{array}{l}\text { Jesuita desde 21-I-1741. Cuarto voto, el 10-X-1756. Autor de: } \\
\text { Erguido Olympo, o el más elevado de los montes, trasladado al } \\
\text { ameno plantel de la América Setentrional. Arco triunfal que la } \\
\text { metropolitana de México erigió en la pública entrada del } \\
\text { Excmo. Sr. Marqués de Cruillas, virrey de la N. E., México, } \\
\text { 1761. 2. El más vivo bosquejo de la Trinidad Santíssima. } \\
\text { Sermón que, en el día en que la Iglesia, nuestra Madre, celebra } \\
\text { al ínclyto y gloriosíssimo patriarcha fundador de la Compañia } \\
\text { de Jesús S. Ignacio de Loyola, cuyo altar honraban, como } \\
\text { siempre, los gloriosíssimos Patriarchas Santo Domingo y San } \\
\text { Francisco, predicó en la Casa Professa de México, México, } \\
\text { 1766, actividad que no pudo seguir en el destierro porque estuvo } \\
\text { muchos años apoplético }{ }^{113} \text {. }\end{array}$ & $\begin{array}{l}\text { *Tehuacán de las Granadas, 5- } \\
\text { XI-1722-†Bolonia, 11-XII- } \\
1795 .\end{array}$ \\
\hline $\begin{array}{l}\text { RODRÍGUEZ, } \\
\text { Francisco Javier. } \\
\text { CASTILLA y MEX. }\end{array}$ & $\begin{array}{l}\text { Predicador. En } 1767 \text { era maestro de } \\
\text { Escritura y prefecto de Moral en el } \\
\text { Colegio Máximo de México. } \\
\text { Residió en Bolonia. Se dedicó a } \\
\text { escribir cartas a los ricos de Nueva } \\
\text { España para que enviasen dinero a } \\
\text { los jesuitas desterrados (“En este } \\
\text { punto no hubo industria que él no } \\
\text { usara para bien de sus } \\
\text { desconsolados compañeros, no } \\
\text { teniendo tiempo más gustoso que el }\end{array}$ & $\begin{array}{l}\text { Habiendo estudiado filosofía en la universidad de Salamanca, } \\
\text { ingresó en el noviciado de Villagarcía el 18-VI-1748. Cuarto } \\
\text { voto, 15-VIII-1766. "Los caritativos bienhechores que lo } \\
\text { amaron en la América, lo socorrieron en el destierro, y estos } \\
\text { socorros no servían sólo a él, pues siempre tenía abiertas las } \\
\text { manos para socorrer a los miserables. Con las cartas llenas de } \\
\text { caritativa elocuencia escritas a los americanos, hizo que muchos } \\
\text { se movieran a compasión de sus necesitados parientes y los } \\
\text { socorrieron". }\end{array}$ & $\begin{array}{l}* \text { Vermillo (Zamora) } 21 \text { (25, } \\
\text { según Zelis)-III-1733- } † \text { Bolonia, } \\
12-\mathrm{X}-1792 .\end{array}$ \\
\hline
\end{tabular}

\footnotetext{
${ }^{112}$ Ibíd., 1767-1796, vol. II: 229.

${ }^{113}$ Sebastián aclara que nació "en las aguas del Océano a bordo del bajel en que viajaban sus padres, que de la Villa de Puerto Real en la Andalucía se conducían con toda su familia a la Nueva España”, Sebastián, 1767-1796, vol. II: 337-341.
}

114 Antonio Astorgano Abajo y Fuensanta Garrido Domené. Panorama esquemático ... 60-120. 


\begin{tabular}{|c|c|c|c|}
\hline & $\begin{array}{l}\text { que empleaba en procurar } \\
\text { aliviarlos"114. }\end{array}$ & & \\
\hline $\begin{array}{l}\text { SACRAMEÑA, Juan } \\
\text { José. AND. y MEX. }\end{array}$ & $\begin{array}{l}\text { Poeta. Primer catedrático de } \\
\text { gramática en el Colegio de } \\
\text { Guadalajara. En } 1767 \text { estaba en el } \\
\text { Colegio de Guatemala (prefecto de } \\
\text { la Anunciación y confesor). }\end{array}$ & $\begin{array}{l}\text { Jesuita desde 12-V-1749. Cuarto voto, } 15-\text { VIII-1766. Publicó } \\
\text { un soneto en la Vida de San Josef de José Ignacio Vallejo } \\
\text { (Cesena, 1774. Por Gregorio Biasini). En Guatemala había } \\
\text { dicho un panegírico al arzobispo Figueredo }{ }^{115} \text {. }\end{array}$ & $\begin{array}{l}* \text { Medina Sidonia (España), } 13- \\
\text { IV-1733- } \uparrow \text { Medina Sidonia, } \\
1814 .\end{array}$ \\
\hline $\begin{array}{l}\text { STERNKIANOWSKI, } \\
\text { Antonio. ALEM. y } \\
\text { MEX. }\end{array}$ & $\begin{array}{l}\text { Cronista. Misionero en la } \\
\text { Tarahumara en 1767. St. Clair } \\
\text { Segurado nos advierte que } \\
\text { Sterkianowski es "poco fiel a las } \\
\text { fechas y demasiado inclinado a la } \\
\text { apología" }\end{array}$ & $\begin{array}{l}\text { Jesuita desde 27-X-1753. Cuarto voto, el 2-II-1765. Pasó a } \\
\text { México en 1755. En su patria natal escribió unas memorias } \\
\text { sobre las misiones (Destierro de los jesuitas de Sonora y } \\
\text { Sinaloa, Biblioteca Nacional de Roma, Fondo, Jesuitas, T. } \\
\text { 1412). La parte referida a Sinaloa está basada en las cartas que, } \\
\text { con este fin, le escribió el P. Francisco Ita (Hita), desde prisión. }\end{array}$ & $\begin{array}{l}\text { *Megamedriche (Moravia, } \\
\text { República Checa), 12-I-1728- } \\
\dagger ¿ \text { ? }\end{array}$ \\
\hline $\begin{array}{l}\text { TARROZ (TARRÓS) } \\
\text { ARANDES, Ramón. } \\
\text { ARA. y MEX. }\end{array}$ & $\begin{array}{l}\text { Geógrafo. En } 1767 \text { estudiaba } \\
\text { Teología en el Colegio Máximo de } \\
\text { México (escolar inválido). En Italia } \\
\text { residió en Castel San Pedro, Imola } \\
\text { y Bolonia. }\end{array}$ & $\begin{array}{l}\text { Jesuita desde } 24-\mathrm{IV}-1759 \text {, no sacerdote. Aprendió astronomía y } \\
\text { álgebra, y construyó varios relojes de sol. Era instruido en } \\
\text { geografía y realizó varios mapas, entre ellos uno del reino de } \\
\text { Cataluña }^{117} \text {. }\end{array}$ & $\begin{array}{l}\text { *Tarragona, 12-II-1744- } \\
\text { †Bolonia, 16-XII-1794. }\end{array}$ \\
\hline $\begin{array}{l}\text { UTRERA ROJANO, } \\
\text { José de. AND. y } \\
\text { MEX. }\end{array}$ & $\begin{array}{l}\text { Misionero y filósofo. En } 1767 \text { era } \\
\text { prepósito de la Casa Profesa de } \\
\text { México. Penúltimo provincial en } \\
\text { Italia. Enterrado en la Iglesia de } \\
\text { Santa María La Mayor de Bolonia } \\
\text { (Libro VII, a.d.). Sucesor de } \\
\text { Cayetano de la Gándara en el }\end{array}$ & $\begin{array}{l}\text { Jesuita desde 19-X-1722. Cuarto voto desde } 23-X-1740 \text {. Había } \\
\text { sido visitador de la Provincia y superior de misioneros. Escribió } \\
\text { un curso de filosofía (1738). Fue rector del Colegio de } \\
\text { Zacatecas. Hay una aprobación suya (México, } 13 \text { de agosto de } \\
\text { 1749) para el Sermón de la inclyta Santa Mónica, del P. José } \\
\text { Carrillo (México, 1749) y otra (4 de agosto de } 1751 \text { ) sobre Lobo } \\
\text { evangélico el Sr. San Ignacio de Loyola, por Fr. José de la Cruz }\end{array}$ & $\begin{array}{l}\text { *Vélez Málaga (España), 5-X- } \\
\text { 1707-†Bolonia, 1-XII-1776. }\end{array}$ \\
\hline
\end{tabular}

\footnotetext{
${ }^{114}$ Ibíd., 1767-1796, vol. II: 233.

${ }^{115}$ Lagrimas de las dos Americas, la Meridional, donde tuvo el mas lucido oriente; la Septentrional, donde tuvo el mas lugubre ocaso, el illmo. sr. dr. d. Francisco Joseph de Figueredo y Victoria ... dignissimo arzobispo de Goatemala, 1766.

${ }^{116}$ Saint Clair Segurado, 2005: 111, nota.

${ }^{117}$ Sebastián, 1767-1796, vol. II: 304.
}

115 Antonio Astorgano Abajo y Fuensanta Garrido Domené. Panorama esquemático ... 60-120. 


\begin{tabular}{|c|c|c|c|}
\hline & $\begin{array}{l}\text { provincialato, Félix de Sebastián } \\
\text { no alude a sus obras }{ }^{118} \text {. }\end{array}$ & $\begin{array}{l}\text { (México, 1751). También escribió Vida del P. José Javier } \\
\text { Molina, de la Compañía de Jesús. }\end{array}$ & \\
\hline $\begin{array}{l}\text { UGARTE DE } \\
\text { VELASCO, Hilario. } \\
\text { MEX. }\end{array}$ & $\begin{array}{l}\text { Físico y matemático. Estudiante de } \\
4^{\circ} \text { de Teología (actuante de Prima) } \\
\text { en el Colegio Máximo de México } \\
\text { en 1767. Residió en Castel San } \\
\text { Pedro y Bolonia (ya en 1773). }\end{array}$ & $\begin{array}{l}\text { Jesuita desde } 28 \text {-VI-1756. Aprendió griego, matemáticas y } \\
\text { álgebra; escribió varios tratados de Física y Matemáticas. }\end{array}$ & $\begin{array}{l}\text { * Hacienda de San Isidro del } \\
\text { Torreón, misión jesuita de } \\
\text { Bocas (Durango), 20-I-1740- } \\
\text { †Roma, 9-VIII-1796. }\end{array}$ \\
\hline $\begin{array}{l}\text { VENEGAS, Miguel. } \\
\text { MEX. Biografiado } \\
\text { por Salvador de la } \\
\text { Gándara (México, } \\
\text { 1765). } \\
\text { No fue expulso. }\end{array}$ & $\begin{array}{l}\text { Profesor e historiador. Gozó de } \\
\text { fama erudita y culta. Su obra más } \\
\text { conocida es Noticia de la } \\
\text { California y de su conquista } \\
\text { temporal y espiritual hasta el } \\
\text { tiempo presente. Como nunca } \\
\text { estuvo en las misiones de } \\
\text { California, la obra no satisfizo a } \\
\text { Juan Jacobo Baegert, Miguel del } \\
\text { Barco y Francisco Javier Clavigero. }\end{array}$ & $\begin{array}{l}\text { Ingresó en el noviciado de Tepozotlán el 30-VIII-1700. Cuarto } \\
\text { voto, el 2-II-1715. Maestro de latín, retórica y filosofía en el } \\
\text { Colegio Máximo y catedrático de teología moral (1714). Más } \\
\text { tarde, retirado a la vida del campo, estuvo } 45 \text { años dedicado a } \\
\text { escribir y a estudiar botánica en la comarca vecina del convento. } \\
\text { Publicó: El apóstol mariano representado en la vida del V. P. } \\
\text { Juan Maria de Salvatierra, [...] conquistador apostólico de las } \\
\text { Californias, México, 1754. 2. Manual de párrocos, para } \\
\text { administrar los santos sacramentos, México, 1783. A } \\
\text { instancias del obispo don Juan Ignacio de Castoreña y Ursúa, } \\
\text { escribió la vida del ermitaño y misionero Juan González } \\
\text { (Beristáin). }\end{array}$ & $\begin{array}{l}\text { *Puebla, } 4-X-1680-\uparrow \text { Hacienda } \\
\text { de Chicomocelo (Morelos, } \\
\text { México), 25-VI-1764. }\end{array}$ \\
\hline $\begin{array}{l}\text { VENTURA, Lucas. } \\
\text { ARAGÓN y MEX. }\end{array}$ & $\begin{array}{l}\text { Misionero. En } 1767 \text { era procurador } \\
\text { general de la California en la } \\
\text { misión de Loreto. Residió en } \\
\text { Bolonia. }\end{array}$ & $\begin{array}{l}\text { Ingresó en el noviciado de Tarragona, el 25-XI-1749. Cuarto } \\
\text { voto, el } 25 \text {-III-1765. Fue a México en la misión dirigida por el } \\
\text { padre Ignacio Lizazoain, que será el último provincial mexicano } \\
\text { en Italia. "A petición de algunos nuestros escribió unas } \\
\text { Memorias de la California, de las que se valió el difunto padre } \\
\text { Clavijero para escribir la Historia de aquella provincia que en } \\
\text { lengua italiana salió a luz después de su muerte"119. }\end{array}$ & $\begin{array}{l}\text { Muel (Zaragoza), 2-V-1727- } \\
\text { †Bolonia, 9-XII-1793. }\end{array}$ \\
\hline $\begin{array}{l}\text { VIVAR (DÍAZ DE } \\
\text { VIVAR), Francisco. } \\
\text { MEX. Retornó a }\end{array}$ & $\begin{array}{l}\text { Poeta. En } 1767 \text { estaba de maestro } \\
\text { de Filosofía en el Colegio de } \\
\text { Guadalajara. }\end{array}$ & $\begin{array}{l}\text { Jesuita desde 29-III-1753. Cuarto voto, el 2-II-1769. Publicó un } \\
\text { soneto en la Vida de San Josef, de José Ignacio Vallejo (Cesena, } \\
\text { 1774. Por Gregorio Biasini). }\end{array}$ & $\begin{array}{l}\text { *Portobelo (Panamá), 2-IV- } \\
\text { 1735-†Barcelona, 1-VIII-1802. }\end{array}$ \\
\hline
\end{tabular}

${ }^{118}$ Ibíd., 1767-1796, vol. I: 288.

${ }^{119}$ Ibíd., 1767-1796, vol. II: 269.

116 Antonio Astorgano Abajo y Fuensanta Garrido Domené. Panorama esquemático ... 60-120. 


\begin{tabular}{|c|c|c|c|}
\hline España en 1798. & & & \\
\hline $\begin{array}{l}\text { ZELIS MORENO, } \\
\text { Rafael de. MEX. }\end{array}$ & $\begin{array}{l}\text { Cronista de la expulsión. Estudiaba } \\
\text { letras humanas en el Colegio de } \\
\text { Tepozotlán en } 1767 \text {. Secularizado } \\
\text { en Bolonia antes de la extinción de } \\
\text { la Compañía, donde residía en } 1771 \\
\text { y, con posterioridad, vivió en } \\
\text { Roma. }\end{array}$ & $\begin{array}{l}\text { Jesuita desde 6-III-1765. Sacerdote secular ordenado el } 29 \text {-IX- } \\
1775 \text {. Dejó manuscritas dos crónicas: } 1^{\text {a }} \text {. Catálogo de los } \\
\text { sujetos de la Compañía de Jesús que formaban la Provincia de } \\
\text { México el día del arresto, } 25 \text { de junio de } 1767 \text {, formado en } \\
\text { Roma por don Rafael Zelis. } 2^{\text {a }} \text {. Viajes en su destierro del P. } \\
\text { Rafael de Zelis, de la Compañia de Jesús. Publicadas por } \\
\text { Mariano Cuevas }{ }^{120} \text {. }\end{array}$ & $\begin{array}{l}\text { *Veracruz, 23-X-1747- } \\
\dagger \text { Bolonia, 25-VII-1798. }\end{array}$ \\
\hline
\end{tabular}

${ }^{120}$ Publicadas en Cuevas, 1944: 15-177 y 180-229. Nosotros manejamos el Catálogo de los sujetos de la Compañia de Jesús que formaban la Provincia de México el día del arresto, 25 de junio de 1767, formado en Roma por don Rafael Zelis, México, Imprenta de I. Escalante, 1871.

117 Antonio Astorgano Abajo y Fuensanta Garrido Domené. Panorama esquemático ... 60-120. 


\section{Referencias}

\section{Archivos}

AHL (Archivo Histórico de Loyola), Escritos de jesuitas del siglo XVIII, Caja 06, $\mathrm{n}^{\mathrm{o}} 01$. Papeles de Lorenzo Hervás

AHL, Luengo, Manuel, Diario de la expulsión de los jesuitas de los Dominios del Rey de España, al principio de sola la Provincia de Castilla la Viexa, después más en general de toda la Compañia, aunque siempre con mayor particularidad de la dicha Provincia de Castilla. 63 tomos.

Biblioteca Comunal del Archiginnasio de Bolonia. Sebastián, Félix de (1767-1796), Memorias de los Padres y Hermanos de la Compañia de Jesús de la Provincia de Nueva España, vol. I (años 1767-1785) y vol. II (años 1786-1796), mss. A-531 y A-532.

\section{Bibliografía}

Alva Rodríguez, Inmaculada (2011), "Francisco Javier Alegre (1729-1788): una aproximación a su obra teológica", Anuario de Estudios Americanos, Sevilla, no 68/1, pp. 283-314.

Astorgano Abajo, Antonio (2004), "La Biblioteca jesuítico-española de Hervás y Panduro y su liderazgo sobre el resto de los ex jesuitas", Hispania Sacra, Madrid, n ${ }^{\circ} 112$, pp. 182-190.

Astorgano Abajo, Antonio (2007), "Prólogo", en Hervás y Panduro, Lorenzo (2007), Biblioteca jesuitico-española, Madrid, Libris, pp. 11-90.

Astorgano Abajo, Antonio (2009a), "Esbozo de la Literatura de los jesuitas portugueses expulsos", Revista História Unisinos XIII/3, pp. 265-283.

Astorgano Abajo, Antonio (2009b), "La Literatura de los jesuitas portugueses expulsos. Recuerdo de los centenarios del marqués de Pombal y de Lorenzo Hervás y Panduro", Boletín de la Real Academia de Extremadura de las Letras y las Artes, Trujillo (España), nº XVII, pp. 305-417.

Astorgano Abajo, Antonio (2009c), "Para uma periodização da Literatura dos jesuitas portugueses expulsos (1759-1814)", Brotéria. Cristianismo e Cultura, Lisboa, no 169/2, pp. 315-336.

Astorgano Abajo, Antonio (2009d), "El marqués de Pombal: según los jesuitas expulsados de España”, Razón y Fe, Madrid, no 1334 (diciembre 2009), pp. 359-374.

Astorgano Abajo, Antonio (2009e), "Hervás y Panduro y sus amigos ante la mexicanidad". En M. Koprivitza Acuña, M. Ramos Medina, C. Torales Pacheco, J. Mª Urkía y S. Yano Bretón (eds.), Ilustración en el mundo hispánico: preámbulo de las Independencias, Tlaxcala, pp. 201-254. 
Astorgano Abajo, Antonio (2009f), "Floridablanca y el jesuita Hervás y Panduro, una relación respetuosa", Res publica. Revista de Filosofía Política, Murcia, nº 22, pp. 325-362.

Astorgano Abajo, Antonio (2009g), La Literatura de los jesuitas vascos expulsos (17671815), Madrid. Discurso de ingreso en la Real Sociedad Bascongada de Amigos del País. Contestación de Emilio Palacios.

Astorgano Abajo, Antonio (2014a), "Bosquejo de la literatura de los jesuitas mexicanos expulsos a través de la Biblioteca Jesuítico-Española de Hervás y Panduro". En Torales Pacheco, Cristina y Casas García, Juan Carlos (coords.) Coloquio internacional "Extrañamiento, extinción y restauración de la Compañía de Jesús, La Provincia mexicana”, México, noviembre de 2013 (en imprenta).

Astorgano Abajo, Antonio (2014b), "La imprenta de Biasini, como punto de encuentro de los jesuitas mexicanos expulsos", Syntagma. Revista del Instituto de Historia del libro y de la lectura, Salamanca, no 3 (2014) (en imprenta). Monográfico sobre Bodoni y su tiempo.

Bangert, William V. (1981), Historia de la Compañia de Jesús, Santander: Editorial Sal Terrae.

Batllori, Miquel (1966), La cultura hispano-italiana de los jesuitas expulsos. Madrid.

Beristáin de Souza, José Mariano (1816-1821), Biblioteca hispano-americana setentrional, o Catálogo y noticias de literatos que, nacidos o educados o florecientes en la América Setentrional, han dado a luz algún escrito o lo han preparado para la prensa, México, 3 vols.

Cuevas, Mariano (1944), Tesoros documentales de México, siglo XVIII. Priego, Zelis, Clavijero. México.

Decorme, Gerardo (1914), Historia de la Compañía de Jesús en la República Mexicana durante el siglo XIX. Vol. I. Restauración y vida de secularización 1816-1848, Guadalajara, 2 vols.

Decorme, Gerardo (1941), La obra de los jesuitas mexicanos durante la época colonial 1572-1767. Vol. I. Fundaciones y Obras. Vol. II. Las Misiones, México.

Dunne, Peter Masten (1937), "The expulsión of the Jesuits fron New Spain, 1767”, MidAmerica. An Historical Review, Chicago, (1937, January), vol. 19, $\mathrm{n}^{\mathrm{o}} 1$.

Hervás y Panduro, Lorenzo (1800), Catálogo de las lenguas, Madrid, vol. I.

Hervás y Panduro, Lorenzo (2007), Biblioteca jesuitico-española, Madrid: Libris. Edición de A. Astorgano.

Hervás y Panduro, Lorenzo (2008), http:/www.cervantesvirtual.com/bib_autor/hervasypanduro/. Dirigida por Antonio Astorgano. Contiene casi todo lo publicado de y sobre Hervás.

Montané Martí, J. C. (1999), La Expulsión de los Jesuitas de Sonora, México. 
Pradeau, F. A. (1959), La expulsión de los Jesuitas de las Provincias de Sonora, Ostimuri y Sinaloa en 1767, México.

Quiñones Melgoza, Jorge (2005), "Las obras publicadas de jesuitas novohispanos del siglo XVIII: Abad, Alegre, Clavigero, Landívar y Maneiro", Memorias del XVIII Congreso del pensamiento novohispano, San Luis Potosí, 2005, pp. 374-382.

Ronan, Charles E. (1977), Francisco Javier Clavigero. S.J (1731-1787) figure of the Mexican Enlightenment: his life and works, Roma.

Saint Clair Segurado, Eva María (2005), Expulsión y exilio de la Provincia jesuita mexicana (1767-1820), Alicante.

Uriarte, José de Eugenio de (1904-1916), Catálogo razonado de obras anónimas y seudónimas de autores de la Compañia de Jesús pertenecientes a la Antigua Asistencia española: con un apéndice de otras de los mismos, dignas de especial estudio (28 sept. 1540-16 agosto 1773), Madrid, 5 vols.

Uriarte, José Eugenio de y Lecina, Mariano (1925-1930), Biblioteca de Escritores de la Compañía de Jesús pertenecientes a la Antigua Asistencia de España desde sus orígenes hasta el año de 1773, Madrid, 2 vols.

Zambrano, Francisco (1966), Diccionario Bio-Bibliográfico de la Compañia de Jesús en México, México, tomo xv.

Zelis, Rafael de (1871), Catálogo de los sujetos de la Compañia de Jesús que formaban la Provincia de México el día del arresto, 25 de junio de 1767, formado en Roma por don Rafael Zelis, México: Imprenta de I. Escalante. 